Louisiana State University

LSU Digital Commons

1997

\title{
A Cuban Convent in the Age of Enlightened Reform: The Observant Franciscan Community of Santa Clara of Havana, 1768-1808.
}

John James Clune Jr

Louisiana State University and Agricultural \& Mechanical College

Follow this and additional works at: https://digitalcommons.Isu.edu/gradschool_disstheses

\section{Recommended Citation}

Clune, John James Jr, "A Cuban Convent in the Age of Enlightened Reform: The Observant Franciscan Community of Santa Clara of Havana, 1768-1808." (1997). LSU Historical Dissertations and Theses. 6473. https://digitalcommons.Isu.edu/gradschool_disstheses/6473

This Dissertation is brought to you for free and open access by the Graduate School at LSU Digital Commons. It has been accepted for inclusion in LSU Historical Dissertations and Theses by an authorized administrator of LSU Digital Commons. For more information, please contact gradetd@lsu.edu. 


\section{INFORMATION TO USERS}

This manuscript has been reproduced from the microfilm master. UMI films the text directly from the original or copy submitted. Thus, some thesis and dissertation copies are in typewriter face, while others may be from any type of computer printer.

The quality of this reproduction is dependent upon the quality of the copy submitted. Broken or indistinct print, colored or poor quality illustrations and photographs, print bleedthrough, substandard margins, and improper alignment can adversely affect reproduction.

In the unlikely event that the author did not send UMI a complete manuscript and there are missing pages, these will be noted. Also, if unauthorized copyright material had to be removed, a note will indicate the deletion.

Oversize materials (e.g., maps, drawings, charts) are reproduced by sectioning the original, beginning at the upper left-hand corner and continuing from left to right in equal sections with small overlaps. Each original is also photographed in one exposure and is included in reduced form at the back of the book.

Photographs included in the original manuscript have been reproduced

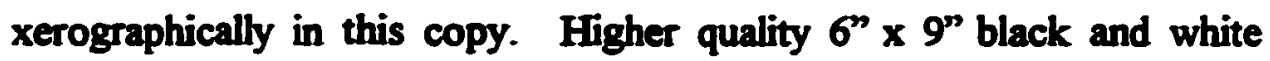
photographic prints are available for any photographs or illustrations appearing in this copy for an additional charge. Contact UMI directly to order.

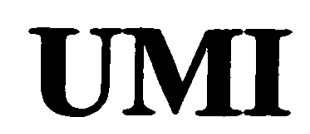

A Bell \& Howell Information Company 300 North Zeeb Road, Ann Arbor MI 48106-1346 USA

$313 / 761-4700 \quad 800 / 521-0600$ 
A CUBAN CONVENT IN THE AGE OF ENLIGHTENED REFORM: THE OBSERVANT FRANCISCAN COMMUNITY OF SANTA CLARA OF HAVANA, $1768-1808$

\author{
A Dissertation \\ Submitted to the Graduate Faculty of the \\ Louisiana State University and \\ Agricultural and Mechanical College \\ in partial fulfillment of the \\ requirements for the degree of \\ Doctor of Philosophy \\ in
}

The Department of History

by

John James Clune, Jr.

B.S., Nicholls State University, 1986

M.A., University of Alabama, 1990

August 1997 
UMI Number: 9808730

Copyright 1997 by

Clune, John James, Jr.

All rights reserved.

UMI Microform 9808730

Copyright 1997, by UMI Company. All rights reserved.

This microform edition is protected against unauthorized copying under Thte 17, United States Code.

\section{UMI \\ 300 North Zeeb Road \\ Ann Arbor, MI 48103}


CCopyright 1997

John James Clune, Jr.

All rights reserved 
To Allison

iii

Reproduced with permission of the copyright owner. Further reproduction prohibited without permission. 


\section{ACKNOWLEDGMENTS}

I am grateful to the Fulbright Commission and the History Department at Louisiana State University for funding this study. I owe a debt of gratitude to a great many people. To my major professor, Paul E. Hoffman, for his encouragement and helpful criticism. To the other members of my examining committee--professors stanley E. Hilton, Victor L. Stater, William V. Davidson--for their comments and criticisms. To the secretaries in the History Department at Louisiana State University, Peggy Seale and Keuren Pinkney, for their patient assistance. To scholars and friends on both sides of the Atlantic-Sherry Johnson, Jane Landers, Douglis Inglis, Justina Sarabia and Paulino Castañeda--who opened their doors to me and shared their wisdom. To my parents, John and Gretchen Clune, and my sisters, Kerry, Bridget and Jenny, for their immeasurable love and support through the years. To my wife's parents, Emmett and Regina Morel, for treating me like their son. To my daughter, Gabrielle, who in nineteen short months of life has logged more air miles and lived in more places than many people do in a lifetime. Finally, to my loving wife, Allison, without whom none of this would have been possible. This work is 
as much the fruit of her labors as it is mine. Her sacrifices have gone far beyond giving moral and financial support. Seven months pregnant she followed me to Spain so that I could see the birth of my first child. Far from home, she lost her father only days before Gabrielle was born. Enduring it all with courage and grace, she has been my rock and my inspiration. 
TABLE OF CONTENTS

ACKNOWLEDGMENTS ........................ IV

ABBREVIATIONS.......................... vii

ABSTRACT $\ldots \ldots \ldots \ldots \ldots \ldots \ldots \ldots \ldots \ldots \ldots \ldots \ldots \ldots$

CHAPTER

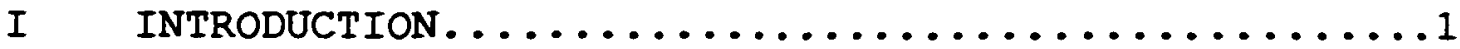

II A HISTORY OE FAILED REFORMS ............... 24

III THE REGLAMENTO OE $1768 \ldots \ldots \ldots \ldots \ldots \ldots \ldots \ldots$

IV A RESPITE EROM COMMUNAL LIEE, 1770-1782.......66

V SUPERNUMERARY ADMISSIONS AND DOUBLE DOWRIES.....100

VI THE RE-ESTABLISHMENT OF COMMUNAL IIEE, $1783 \ldots \ldots .120$

VII SLOW BUT CERTAIN PROGRESS, 1784-1796......... I47

VIII REDEEINING THE ROLE OE THE CONVENT, 1796.......160

IX THE MORATORIUM OF $1797 \ldots \ldots \ldots \ldots \ldots \ldots$

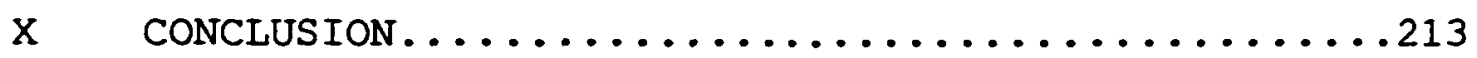

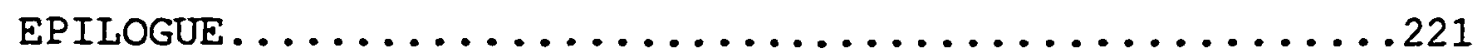

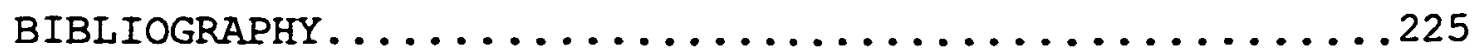

APPENDIX

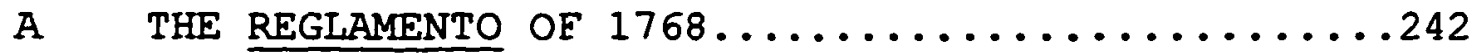

B WEALTH OF FEMALE ORDERS IN $1837 \ldots \ldots \ldots \ldots \ldots \ldots$

C RELIGIOUS POPULATION OF SANTA CLARA, 1768-1811..256

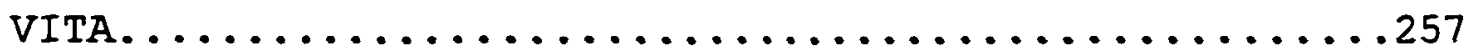

vi 


\section{ABBREVIATIONS}

AGI Archivo General de Indias

SD Audiencia de Santo Domingo

vii 


\section{ABSTRACT}

The reform of Mexican convents in the late eighteenth and early nineteenth century generally has been shown to have been ineffective. I suggest that reform at the Observant Franciscan community of Santa Clara of Havana achieved much better results. While conventual reform in Cuba did not attain perfection, it followed the pattern of administrative, economic and military reform in that it was more effective on the island than it was elsewhere in the Spanish empire.

The success of conventual reform in Havana must be attributed to the diligence of the Spanish Crown. Whereas the reform of convents in Mexico became a local concern after 1780, its counterpart at Santa Clara garnered the attention of Madrid down to the abdication of Charles IV in 1808, and beyond. It must be recognized, however, that effective reform did not always equate to beneficial reform. The same reforms that reduced the number of religious and secular females living at Santa clara and re-established communal life at the convent also divided the community and robbed it of its vibrancy. 


\section{CHAPTER I}

\section{INTRODUCTION}

In 1807 the Commissary General of the Indies for The Franciscan Order, Pablo de Moya, appealed to the Spanish Crown to lift its ban on the admission of novices at the Observant Franciscan community of Nuestra Señora de Santa Clara of Havana. Moya said that the majority of the nuns at the once vibrant community were over the age of sixty, that more than a dozen were over the age of seventy, and that one was over 100. Adding that four were crippled, one was blind, and almost all were afflicted by some infirmity or another, he concluded that "hardly one could be declared healthy." The few who had not been disabled by age, sickness, or handicaps withered under the burden of holding three or four conventual offices simultaneously. ${ }^{1}$ The sad state of affairs at the convent was the result of almost four decades of reform. Since 1768, the Crown had restricted Santa Clara's right to

1 AGI, Ultramar 396, Pablo de Moya to Antonio Porcel, November 10, 1807, copied from book 8, folio 197 of the Secretariat General of the Indies for The Eranciscan Order by Bonifacio González, Secretary General of the Indies for The Franciscan Order, attached to a report of Pablo de Moya to Esteban Varea, March 9, 1815. 
admit novices, and the convent had admitted its last novice in $1794 .^{2}$ The reforms that robbed Santa clara of its lifeblood were indicative of the conventual reforms instituted under the fourth Bourbon king of Spain, Charles III $(1759-1788)$.

In 1759 Charles III inherited a relatively weak monarchy and an empire beset with problems. Far from absolute, the Spanish monarchy was forced to share power with corporate groups. Chief among them were the Church and the nobility. Plagued by a poor system of tax collection, underdeveloped industries, trade barriers, and an inefficient administrative structure, the empire appeared to be in danger of collapsing. ${ }^{3}$

The reformation and rejuvenation of the Spanish empire reached its height under Charles III as officials in Madrid embraced enlightened ideas with regard to military organization, trade regulations, public administration, and the role of the Church. Prior to

2 AGI, Ultramar 396, Pablo de Moya to the Council of the Indies, July 12, 1804.

3 See summary of Bourbon Reforms in Mark A. Burkholder and Lyman L. Johnson, Colonial Latin America, $2 d$ ed. (New York, Oxford University, 1994), 257. 
1762, however, relatively little in the way of real reform took place. In that year the British sent shock waves through the Spanish empire by capturing Havana, a seemingly impregnable fortress city that guarded the route of the Spanish silver fleet. As an occupying force for eleven months, the British gave the colonists a taste of free trade. In the aftermath of the cuban debacle, reform in the Spanish empire took on an added sense of urgency, as the Crown looked for ways to improve defenses and for the money to pay for those improvements. ${ }^{4}$

4 See discussion of Bourbon Reforms in stanley $\mathrm{J}$. Stein and Barbara $\mathrm{H}$. Stein, The Colonial Heritage of Latin America (New York: Oxford University, 1970), 97; For discussion of the Enlightenment in Spain and also of French influences on enlightened reforms in the Spanish empire see Iris H. W. Engstrand, "The Enlightenment in Spain: Influences upon New World Policy," Americas 41 (1985) : 435-36; Richard Herr, The Eighteenth-Century Revolution in Spain (Princeton: Princeton University, 1958), 11-36; Jean Sarrailh, I'Espagne Eclairée de Ia seconde moitié du XVIIIe siécle (Paris: Impr. Nacionale, 1954), 505, 709-711; Arthur S. Aiton, "Spanish Colonial Reorganization Under the Family Compact," Hispanic American Historical Review 12 (1932): 269-280; Allan J. Kuethe and Lowell Blaisdell, "French Influence and the Origins of Bourbon Colonial Reorganization," Hispanic American Historical Review 71 (1991): 579-608; For discussion of the colonial reforms in general see Richard Graham, Independence in Latin America (New York: Knopf, 1972); John Lynch, Bourbon Spain, 1700-1808 (Cambridge Massachusetts: Basil Blackwell Press, 1989); John Lynch, "The Origins of Spanish American Independence," in The Cambridge History of Latin America, ed. Leslie Bethell, 8 vols. (Cambridge: Cambridge University, 1984), 3: 3-50; 
In bolstering defenses, the Crown was forced to innovate, abandoning its policy of stripping corporate groups of their privileges and power. Money and manpower shortages forced the crown to rely on colonial militias rather than on regular spanish troops. To recruit militia members, Madrid offered them admission to the fuero militar. The fuero militar entailed, among other things, the right to be tried before a military tribunal and some fiscal benefits. By joining the militia, creoles and mixed races gained access to privileges previously reserved for peninsulares (individuals born in Spain).5

Jacques A. Barbier, Reform and Politics in Bourbon Chile, 1755-1796 (Ottawa: University of Ottawa, 1980); Jacques A. Barbier, "The Culmination of the Bourbon Reforms, 17871792," Hispanic American Historical Review 57 (1977) : 5168; John R. Fisher, "Critique of 'The Culmination of the Bourbons Reforms," "Hispanic American Historical Review 58 (1978): 83-90; Allan J. Kuethe, "More on 'The Culmination of the Bourbon Reforms': A Perspective from New Granada," Hispanic American Historical Review 58 (1978): 477-480; and Mark A. Burkholder, "The Council of the Indies in the Late Eighteenth Century: A New Perspective," Hispanic American Historical Review 56 (1976): 404-423.

5 Allan J. Kuethe, "Military and Society," in Latin American Revolutions, 1808-1826: Old and New World Origins (Norman: University of Oklahoma, 1994), 71; For discussion of military reforms in the colonial empire see lyle $\mathrm{N}$. McAlister, The "Euero Militar" in New Spain (Gainesville: University of Florida, 1957); Allan J. Kuethe, Military Reform and Society in New Granada, 1773-1808 (Gainesville: University of Florida, 1978); Allan J. Kuethe, Cuba, 17531815: Crown, Military, and Society (Knoxville: University 
To increase revenues and appease restless colonists, the Crown slowly liberalized trade within the empire. In 1765 it opened a number of ports in Spain to direct contact with the Caribbean, thus breaking the monopoly of the House of Trade in Cadiz. Then in 1778 it allowed thirteen Spanish ports to trade with all colonial ports except Vera Cruz and La Guiria (Venezuela). The latter two finally were included in 1789. As a result of these and other measures, the value and volume of colonial trade rose. 6

of Tennessee, 1986); and Christian I. Archer, The Army in Bourbon Mexico, 1760-1810 (Albuquerque: University of New Mexico, 1977).

6 Stein and Stein, Colonial Heritage, 100-101; For discussion of colonial economic reforms see Geoffrey Walker, Spanish Politics and Imperial Trade, 1700-1789 (Bloomington: University of Indiana, 1979); Roland Hussey, The Caracas Company, 1728-1784 (Cambridge, Massachusetts: Harvard University Press, 1934): David A. Brading, Miners and Merchants in Bourbon Mexico, 1763-1810 (New York: Cambridge University Press, 1971); Clement G. Motten, Mexican Silver and the Enlightenment (Philadelphia: University of Pennsylvania Press, 1950); Brian R. Hamnett, Politics and Trade in Southern Mexico, 1750-1821

(Cambridge: Cambridge University Press, 1971); Nils Jacobsen and Hans-Jürgen Puhle, eds., The Economies of Mexico and Peru During the Late Colonial Period, 1760-1810 (Berlin: Colloquium Verlag Berlin, 1986); Juan Carlos Garavaglia, "Economic Growth and Regional

Differentiations: The River Plate Region at the End of the Eighteenth Century," Hispanic American Historical Review 65 (1985): 51-90; John R. Fisher, Allan J. Kuethe, and Anthony McFarlane, eds. Reform and Insurrection in Bourbon 
In Cuba the reforms worked as they were intended, producing an organized, disciplined militia and a booming economy. The success of military reform on the island allowed the Spanish to defeat the British in Florida during the War of American Independence. ${ }^{7}$ In addition to showering the creole militia officers with honors, such as titles of nobility, the Crown gave them generous commercial advantages. Although Cubans tended to be taxed more heavily than colonists elsewhere and were subjected to tighter administrative controls, the economic benefits

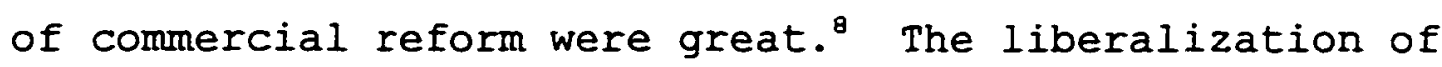

New Granada and Peru (Baton Rouge: Louisiana State University Press, 1991); and Allan J. Kuethe and G. Douglas Inglis, "Absolutism and Enlightened Reform: Charles III, the Establishment of the Alcabala, and Commercial Reorganization in Cuba," Past and Present 109 (1985): 118-143.

7 Kuethe, Crown, Military, and Society, 174-177; Kuethe and Inglis, "Absolutism and Enlightened Reform," 118 .

- Kuethe, Crown, Military, and Society, 174-175; As part of the reform program, the Crown imposed tighter administrative controls, creating new administrative districts and recasting the bureaucracy to make it both more efficient and more responsive to the interests of the mother country; For discussion of administrative reforms in the colonies see Stanley J. Stein, "Bureaucracy and Business in the Spanish Empire, 1759-1804: Failure of a Bourbon Reform in Mexico and Peru," Hispanic American Historical Review 61 (1981): 2-28; Jacques A. Barbier and 
trade in 1765, for example, was instrumental in spurring the growth of Cuba's sugar industry, allowing the island to take advantage of the opportunities that arose in the aftermath of the Haitian Revolution (1791).9

The Church in Cuba, as elsewhere, reaped few benefits from the Bourbon reform program. Under the Spanish Hapsburgs, Church and state had worked together. The

Mark A. Burkholder, "Critique of 'Bureaucracy and Business in the Spanish Empire," Hispanic American Historical Review 62 (1982): 460-77 (includes reply); John Lynch, Spanish Colonial Administration, 1782-1810: The Intendent System in the Viceroyalty of the Rio de la plata (London: Athlone Press, 1958); John R. Fisher, Government and Society in Colonial Peru: The Intendant System, 1784-1814 (London: Athlone Press, 1970); Mark A. Burkholder and Dewitt S. Chandler, From Impotence to Authority: The Spanish Crown and the American Audiencias, 1687-1808 (Columbia, Missouri: University of Missouri, 1977); Herbert J. Priestly. José de Gálvez, Visitor-General of New Spain (1765-1771) (Berkeley: University of California, 1916); and Luis Navarro Garcia, Intendencias en Indias (Seville: Escuela de Estudios Hispano-Americanos, 1959).

9 In 1762 the average Cuban sugar plantation consisted of 320 acres and was worked by six or eight slaves. By 1792 the average size had increased to 700 acres and the average work force had swelled to almost 100 slaves. Ten-thousand acres were under cultivation on the island in 1762. Thirty years later, 160,000 acres were being cultivated. Tonnage harvested rose accordingly, from 10,000 tons in the 1770's to 16,000 tons in the 1790s. Between 1770 and 1790, revenues from trade grew from two million pesos to 16.6 million (Louis A. Pérez, Jr., Cuba: Between Reform and Revolution (Oxford: Oxford University, 1988), 61-63). 
Hapsburgs, mindful of the clergy's ability to fix public opinion, had enlisted clergy as agents of the Spanish Crown. The Spanish Bourbons, particularly Charles III, recognized an inherent danger in this relationship. Aware that the clergy might use its influence against the state, the Bourbons endeavored to weaken and, at the same time, reform this group. A powerful, disloyal, and decadent clergy was a threat to empire because, as the Crown noted in 1787, "the conduct of the people depends in large part on that of the clergy."10

The state was by no means powerless in its struggle with the Church. After all, it enjoyed broad powers as part of the patronato real. "I Although the Crown had

${ }^{10}$ Nancy M. Farriss, Crown and Clergy in Colonial Mexico, 1759-1821: The Crisis of Ecclesiastical Privilege (London: Athlone, 1968), 4-5; Antonio Peire, "Estudio social y económico de los mercedarios de México y el Caribe, 1772-1790," Jahrbuch für Geschichte von Staat, Wirschaft und Gesellschaft Lateinamerikas (Germany) 26 (1989): 113 .

11 The patronato real (royal patronage) granted the Crown far reaching authority in American ecclesiastical affairs. In fact the Crown enjoyed greater authority in the religious affairs of the New World than it did in the religious affairs of Spain. Established in 1493, the patronato was formalized in a series of papal bulls. It assured the crown control over tithe income (i.e., income derived from taxes on agricultural production and livestock), which Madrid was expected to use to maintain churches, convents, hospitals, and schools. It also gave 
challenged papal authority long before the accession of Charles III, only under the fourth Bourbon king did the Crown attempt to strip the clergy of its long-standing fuero eclesiástico, which entailed immunity from civil prosecution. Regular orders in the empire vehemently opposed the reform. None were more obstinate than the Jesuits. ${ }^{12}$

Dedicated to the papacy, the Jesuits refused to acknowledge that royal authority was superior to that of Rome. They were the most independent of episcopal authority and the most resistant to the royal bureaucracy. As educators of the sons of the creole aristocracy, the Jesuits were unsurpassed in their ability to shape public opinion. The order also was very wealthy. Their ultramontanism, ability to influence so many people, and

the Crown the right to nominate all church officials in the New World and to establish churches and monasteries there. Finally, the patronato gave the crown the right to approve any order sent from Rome to America (see J. Lloyd Mecham, Church and State in Latin America: A History of Politico-Ecclesiastical Relations (Chapel Hill: University of North Carolina, 1966); and William Eugene Sheils, King and Church: The Rise and Fall of the Patronato Real (Chicago: Loyola University, 1961).

12 Farriss, Crown and Clergy, 6-10. 
tremendous wealth led Charles III to expel the Jesuits from all his dominions in February of 1767. After the expulsion of the Jesuits, the crown set out to reform the other regular orders in the empire. ${ }^{13}$

Reports reaching Madrid before and after the Jesuit expulsion commented on the relaxed moral discipline of other religious orders, particularly the male ones. ${ }^{14}$ These reports often originated with secular prelates who acquiesced in enlightened policy as a means of selfpreservation. Eighteenth century prelates were forced to cater to the Council of the Indies because the Council rather than the Crown was responsible for restructuring the American episcopate. The tribunal controlled the promotion and appointment of religious as well as civil

13 Josep M. Barnadas, "The Catholic Church in Colonial Spanish America," in The Cambridge History of Latin America, ed. Leslie Bethell, 8 vols (Cambridge: Cambridge University, 1984), 1: 536-537; Lynch, "The Origins of Spanish American Independence, 10; See also Magnus Morner, "The Expulsion of the Jesuits in Light of Eighteenth-Century Regalism," Americas 23 (1966): 156-164.

14 Asunción Lavrin, "Ecclesiastical Reform of Nunneries in New Spain in the Eighteenth Century," Americas 22 (1965): 182 . 
officials. Under such conditions, church officials became less combative. ${ }^{15}$

The moral looseness which plagued male religious orders in the empire did not afflict female orders. Instead, decadence among the female orders generally manifested itself in a variety of more innocuous ways: nuns quarreled among themselves and with their superiors, maintained large numbers of servants, and placed neverending demands on their families for money to cover expenses incurred in the convent. Nonetheless, such behavior drew the attention of officials in Madrid who had committed themselves to stamping out all forms of decadence in religious life. ${ }^{16}$

The primary goal of Bourbon conventual reform, however, was to reestablish communal life in cloistered communities, thereby making them self-sufficient. All other reforms, such as those implemented to reduce the

15 Patricia seed argues, "...church officials became increasingly solicitous of the opinion and goodwill of the royal bureaucracy" (Patricia Seed, To Love, Honor, and obey in Colonial Mexico: Conflicts Over Marriage Choice, 1574-1821 (Stanford: Stanford University, 1988), 167).

16 Lavrin, "Ecclesiastical Reform," 182. 
religious population of convents, were simply a means to this end. Although private life engendered inequalities in the cloister and discouraged less affluent girls from pursuing a religious vocation, the Crown's primary concern lay elsewhere: the Bourbon state perceived private life as a practice by which idle religious siphoned money away from productive members of society. The crown's solution-reforms that blocked the admission of novices and prevented the use of private resources--did not sit well with the nuns. After all, their lifeblood, in the form of novices as well as monetary support, lay outside the convent's walls. ${ }^{17}$

The history of female religious orders in colonial Latin America traditionally has been subordinated to that of their male counterparts. ${ }^{18}$ Too often the "nun" in historiography has been synonymous with Sor Juana Inés de

17 For discussion of the dependency of male religious orders on the outside world see Peire, "Estudio social $y$ económico," 120-127.

18 Two important exceptions include Rubén Vargas Ugarte, S.J., EI monasterio de La Concepción de la ciudad de los Reyes (Lima: Talleres Gráficas de la Editorial Lumen, 1942); and Josefina Muriel, Conventos de monjas en la Nueva España (Mexico: Editorial Santiago, 1946). 
Ia Cruz (1648-1695). 19 Over the past four decades,

however, a few scholars have begun to redress this

imbalance, focusing on specific aspects of conventual

life. Chief among them has been Asunción Lavrin, who has

looked at the social and economic role of convents in

colonial Mexico. ${ }^{20}$

19 Among the classical works on Sor Juana Inés de la Cruz (1648-1695) are: Franchon Royer, The Tenth Muse: Sor Juana Inés de la Cruz (Patterson, New Jersey: St. Anthony Guild Press, 1952), the first biography of Sor Juana in English; and Anita Arroyo, Razón y pasión de Sor Juana (Mexico City: Editorial Porrúa, 1952), which is considered the best Spanish biography of the nun. Though somewhat abated, scholarly interest in sor Juana continues. Among the most important recent works are: Octavio Paz, Sor Juan Inés de la Cruz o las trampas de la fé (Barcelona: SeixBarral, 1982): Margaret Sayers Peden, A Woman of Genius: The Intellectual Autobiography of Sor Juana Inés de la Cruz (Salisbury, Connecticut: Lime Rock Press, 1982); and Stephanie, Merrim, ed.' Eeminist Perspectives on Sor Juana Inés de la Cruz (Detroit, Michigan: Wayne State University, 1991).

20 Works by Asunción Lavrin on the social and economic aspects of conventual life include: "Religious Life of Mexican women in the XVII Century" (Ph.D. diss., Harvard University, 1963); "Ecclesiastical Reform of Nunneries in New Spain in the Eighteenth Century," Americas 22 (1965): 182-203; "The Role of the Nunneries in the Economy of New Spain in the Eighteenth Century," Hispanic American Historical Review 46 (November 1966): 371-93; "Values and Meaning of Monastic Life for Nuns in Colonial Mexico," The Catholic Historical Review 58 (October 1972): 367-87; "Los conventos de monjas en Nueva España," Cahiers des Ameriques Latines (Paris) 8 (1975): 92-122; "El Convento de Querétaro: la administración de sus propiedades en el siglo XVIII," Historia Mexicana 97 
Not surprisingly, Mexico, with its rich and accessible archival sources, has captured the attention of North American as well as Mexican scholars. ${ }^{21}$ on the

(1975): 76-117; "Women in Convents: Their Economic and Social Role in Colonial Mexico," in Iiberating Women's History: Theoretical and Critical Essays, ed. Berenice A. Carroll (Urbana: University of Illinois, 1976), 256-77; "El capital eclesiástico y las élites sociales en Nueva España a fines del siglo XVIII," in Desarrollo histórico de la burguesia en América Latina (Siglos XVIII a XX), ed. Enrique Florescano, (Mexico City: Editorial Nueva Imagen, 1982): "Women and Religion in Spanish America," in Women and Religion in America, ed. Rosemary Radford Ruether and Rosemary Skinner Keller (San Francisco: Harper and Row, 1983), 42-78; "Female Religious," in Cities and Society in Colonial Latin America, ed. Louisa Hoberman and Susan Socolow (Albuquerque: University of New Mexico, 1986), 165-195; and "Lo 'femenino:' Women in Colonial Historical Sources," in Coded Encounters. Writing, Gender, and Ethnicity in Colonial Latin America, ed. F.J. CevallosCandau, J.A. Cole, et al. (Amherst: University of Massachusetts, 1994), 153-176; See also Asunción Lavrin, "Misión de historia e historiografía de la iglesia en el periodo colonial," Historiografía y Bibliografía, Suplemento de Añuario de Estudios Americanos 46 (1989): 53 .

21 Others who have contributed to our understanding of the social and economic history of Mexican convents include: Josefina Muriel, Las indias caciques de Corpus Christi (Mexico City: Universidad Nacional Autónoma de México, 1963); Sister Ann Miriam Gallagher, "The Family Background of the Nuns of Two Monasterios in Colonial Mexico: Santa Clara de Querétaro, and Corpus Christi of Mexico City (1724-1822)" (Ph.D. diss., Catholic University of America, 1972): Jorge René Marmolejo González, "Confesores y mujeres en el Obispado de Puebla, Siglo XVIII," in El placer de pecar y el afán de normar, ed. Seminario de Historia de las Mentalidades (Mexico City: Joaquín Mortiz, 1987), 147-166; N. Salazar de la Garza, La 
occasions that Mexico has not been the focus of study, usually another colonial center has assumed the role. ${ }^{22}$ Most recently, American scholars have begun to use the autobiographical accounts of nuns as windows to the past. ${ }^{23}$ Across the Atlantic, Spanish scholars have pored

Vida común en los conventos de monjas de la ciudad de Puebla (Puebla, Mexico: Biblioteca Angelopolitana, Gobierno del Estado de Puebla, Secretaría de Cultura, 1990): and William Francis Allen, "Capital Formation and Lending: The Role of the Church in Guadalajara, 1750-1800" (Ph.D. diss., Tulane University, 1988).

22 See the discussion on convents of Cuzco in Donald I. Gibbs, "Cuzco, 1680-1710: An Andean City Seen Through Its Economic Activities" (Ph.D. diss., University of Texas, 1979); See discussion of the role of convents in the economy of Lima in Brian R. Hamnett, "Church Wealth in Peru: Estates and Loans in the Archdiocese of Lima in the Seventeenth Century," Jahrbuch für Geschichte von Staat, Wirschaft und Geselischaft Lateinamerikas 10 (1973): 113132; See Luis Martín, Daughters of the Conquistadores: Women of the Viceroyalty of Peru (Albuquerque: University of New Mexico, 1983) for discussion of tensions between nuns in the convents of colonial Peru; For Brazil see three studies by Susan A. Soeiro: "A Baroque Nunnery: The Economic and Social Role of a Colonial Convent: Santa Clara do Desterro, Salvador, Bahia, 1677-1800" (Ph.D. diss., New York University, 1974); "The Social and Economic Role of the convent: Women and Nuns in Colonial Bahia, 1677-1800," Hispanic American Historical Review 54 (1974) : 209-232; "The Eeminine Orders in Colonial Brazil: Economic, Social, and Demographic Implications, 1677-1800" in Latin American Women: Historical Perspectives, ed. Asunción Lavrin (Westport Connecticut: Greenwood Press, 1978), 173-197.

23 Confessors often encouraged nuns to write about themselves as a means of resolving their personal problems 
over primary documents and produced a respectable body of work on the social and economic history of convents. However, Spanish scholars, like their American counterparts, have tended to focus their research on colonial centers to the neglect of the periphery. ${ }^{24}$ The

and exploring their inner selves (Lavrin, "Female Religious," 185); Examples of works which analyze autobiographical writings include: Electa Arenal "Convent as Catalyst for Autonomy: Two Hispanic Nuns of the Seventeenth Century," in Women in Hispanic Literature: Icons and Fallen Idols, ed. Beth Miller (Berkeley: University of California, 1983); Electa Arenal and Stacey Schlau, Untold Sisters: Hispanic Nuns in Their Own Works, trans. by Amanda Powell (Albuquerque: University of New Mexico, 1989); Kathleen Myers, "The Addressee Determines the Discourse: The Role of the Confessor in the Spiritual Autobiography of Madre María de San Josef (1656-1719)," Bulletin of Hispanic Studies 69 (1992): 39-47; Kathleen $A$. Myers, "A Glimpse of Family Life in Colonial Mexico: A Nun's Account," Latin American Research Review 28 (1993): 63-87; and María Ferreccio Podestá, ed., Relación autobiográfica of Sor Ursula suarez (Santiago: Academia Chilena de Historia, 1984); Kathleen A. Myers and Amanda Powell, A Wild Country Out in the Garden: The Spiritual Autobiography of Madre María de San José (Bloomington: Indiana University (In press)).

24 See Pilar Foz y Eoz, La revolución pedagógica en Nueva España: 1754-1820, 2 vols. (Madrid: CSIC, 1981); María H. Sánchez Rodríguez, "La mujer, el amor y la religión en el Antiguo Régimen," in La mujer en la historia de España (siglos XVI-XX). Actas de las Segundas Jornadas de Investigación interdisciplinaria organizadas por el Seminario de Estudios de la Mujer de la Universidad Autónoma de Madrid (Madrid: Universidad de Autónoma de Madrid, 1984), 35-58; Cristina Segura, ed. La voz del silencio: S. VIII-XVIII. Fuentes directas para la historia de las mujeres (Madrid: Colección Laya, 1992); 
perception of the periphery as insignificant, which it actually was for much of the colonial period, has contributed to this neglect. Cuba's experience is indicative of a peripheral colony. The island was relegated to backwater status in

Religiosidad femenina: expectativas y realidades (siglos XIII-XVIII) (Madrid: Colección Laya, 1991); I. Arenas Erutos, "El convento de Jesús María en el México criollo del siglo XVII," María Justina Sarabia Viejo, "El monacato femenino y problemática indigena en la Nueva España del siglo XVIII," and R. Loreto López, "Los espacios de la vida cotidiana en los conventos de calzadas de la ciudad de Puebla (1765-1773)," in Actas del I Congreso

Internacional del Monacato Femenino en España, Portugal y América (1492-1992), ed. Jesús Paniagua Pérez and María Isabel Viforcos Marinas (León: Secretariado de Publicaciones de la Universidad de León, 1993), 1: 143154, 173-185, and 201-216, respectively; María Justina Sarabia Viejo, "Controversias sobre la "vida común" ante la reforma monacal femenina en México," in Actas del II Congreso Internacional del Monacato Femenino en España, Portugal, y América (1492-1992) (Mexico: DE, 1995), 583592; María Justina Sarabia Viejo, "La Concepción de Corpus Christi. Raza y vida conventual femenina en México, siglo XVIII," and María M. Ciudad, "Aspectos socioeconómicos del monacato femenino en la Guatemala colonial," in

Manifestaciones religiosas en el mundo colonial (Mexico: UIA-INAH-CONDUMEX, 1994), 2: 15-27, and 53-64; and Antonio Ignacio Laserna Gaitán, "El último intento de reforma de los monasterios femeninos en Perú colonial: el auto del Arzobispo Parada de 1775," Añuario de Estudios Americanos 52 (1995): 253-287; For neglect of the Cuban colonial Church in general see Juan Bosco Amores Carredano, "Historiografía española sobre Cuba colonial," Revista de Indias 50 (1990): 254; and John M. Kirk, "Religion and Politics in Revolutionary Cuba: A Bibliographical Guide," InterAmerican Review of Bibliography 37 (1987): 329. 
the early-sixteenth century with the conquests of the Aztec and Inca civilizations. Thereafter, it became Iittle more than a stopover for ships on their way from or to the lucrative mainland, before finally emerging from its slumber in the late eighteenth century with the onset of the sugar boom.

Church fortunes on the island fluctuated with those of the colony. For much of the sixteenth and seventeenth centuries self-inflicted ailments also crippled the Church. Chief among these were a mediocre higher clergy; an ignorant, venal, and often licentious lower clergy; and long-standing conflicts between civil and religious officials and among the religious themselves. Pirate raids and natural disasters, such as earthquakes and hurricanes, added to the Church's woes. ${ }^{25}$

In the modern era, the political climate in Cuba has discouraged scholars from pursuing research projects on colonial Cuba. Until recently, North American scholars found the island's archives virtually inaccessible, while their Cuban counterparts have tended to concern themselves

25 John M. Kirk, Between God and Party: Religion and Politics in Revolutionary Cuba (Tampa: University of South Elorida, 1989), 6, 9-10. 
with historical questions that are related to the interests of the revolutionary state. ${ }^{26}$ Nonetheless, North American and exiled Cuban scholars have produced a notable body of work on the role of the sugar boom in secularizing Cuban society. Manuel Moreno Fraginals even has coined the term "sugar secularization" to describe the role that the sugar boom played in secularizing Cuban society. According to Moreno Fraginals, sugar secularization manifested itself in the "jettisoning" of religious names from sugar mills in early nineteenth century Cuba. ${ }^{27}$ Biographies of colonial bishops also are

26 For discussion of the accessibility of Cuban archives see Louis A. Pérez, Jr., "Twenty-Eive Years of Cuban Historiography: Views from Abroad," Cuban Studies 18 (1988): 87-101; For discussion of the bias of Cuban scholarship see Louis A. Pérez, Jr., "In service to the Revolution: Two Decades of Cuban Historiography, 19591979," Hispanic American Historical Review 60 (1980): 7989.

27 Manuel Moreno Fraginals, El ingenio: complejo económico social cubano del azucar (Havana: Editorial de Ciencias Sociales, 1964); See also Manuel Moreno Fraginals, "Iglesia e ingenio," Revista de la Biblioteca Nacional José Martí (Cuba) 5, nos. 1-4 (January-December 1963): 11-28; Manuel P. Maza, "The Cuban Church: True Struggles and False Dilemmas: The Historical Characteristics of the Cuban Catholic Church and their impact on the 1959-1960 Episcopal Documents" (M.A. Thesis, Georgetown University, 1982); John M. Kirk, Between God and Party: Religion and Politics in Revolutionary Cuba (Tampa: University of South Florida, 1989); Manuel P. 
well represented in the historiography of the Cuban Church. ${ }^{28}$

With access to rich archival sources, Spanish scholars have produced much of what has been written on the colonial Church in Cuba and on female religious life in the colony. ${ }^{29}$ A prime example of this is Ismael Testé, Historia eclesiástica de Cuba, not only the most detailed history of the Church in Cuba but also the best previous

Maza, "Clero católico y esclavitud en Cuba siglos XVI al XIX: ensayo de sintesis," Estudios Sociales (Dominican Republic) 23 (1990): 17-60; Julio Angel Carreras, "Terratenientes e Iglesia en Cuba colonial," Universidad de la Habana 196-197 (1972): 147-157.

28 Fernando Fernández Escobio, El Obispo Compostela y la Iglesia Cubana del siglo XVII (Miami: Rapid Printing, 1983); Eduardo Torres-Cuevas, Obispo Espada: Ilustración, reforma y antiesclavismo (Havana: Editorial de Ciencias Sociales, 1990): Miguel Figueroa y Miranda, Religión y politica en la Cuba del siglo XIX: Obispo Espada visto a la luz de los Archivos Romanos, 1802-1832 (Miami: Ediciones Universal, 1975); The eighteenth-century visita of Bishop Pedro Agustín Morell de Santa Cruz also has been published by a Cuban scholar. See Pedro Agustín Morell de Santa Cruz, La vista eclesiástica, introduction by César Garcia del Pino (Havana: Editorial de Ciencias Sociales, 1985).

29 Examples include Emilia Cobos Mancebo, "El convento de San Francisco de Santiago de Cuba en el siglo XVIII," Añuario de Estudios Americanos 13 (1956): 105-123; and Juan García Palacios, Sínodo de Santiago de Cuba de 1681 (Madrid-Salamanca: CSIC col, Tierra Nueva e Cielo Nuevo, 1982). 
historical overview of female religious life on the island. ${ }^{30}$ For the colonial period, Angel Huerta Martinez has produced two limited but valuable works: "El clero cubano y su participación en la enseñanza primaria (18001868)," which addresses the roles of male and female religious in Cuban primary education; and "El monacato femenino en Cuba durante el primer tércio del siglo XIX," which provides a good summary of late eighteenth century reforms at Santa Clara. ${ }^{31}$

I discuss the late century reforms at Santa clara in much greater detail than Huerta does, focusing my attention on the reforms instituted at Santa Clara under Charles III and sustained by his son, Charles IV (17881808). I compare those reforms to contemporary reforms

${ }^{30}$ Ismael Testé, Historia eclesiástica de Cuba (Burgos and Barcelona: El Monte Carmelo and Artes Gráficas Medinaceli, 1969-1975), 5 vols.

31 Angel Huerta Martínez, "El clero cubano y su participación en la enseñanza primaria (1800-1868)," Añuario de Estudios Americanos 48 (1991): 479-556; "El monacato femenino en Cuba durante el primer tércio del siglo XIX," in Actas del I Congreso Internacional del Monacato Femenino en España, Portugal, y America, ed. Jesús Paniagua Pérez and María Isabel Viforcos Marinas, (Universidad de León: Secretario de Publicaciones, 1992), 1: 495-511. 
instituted at Mexican convents and suggest that conventual reform in Cuba followed the pattern of military. administrative, and commercial reform, in that it produced better results on the island than it did elsewhere. Also, I suggest that the crown's attitude toward conventual reform approximated its attitude toward other areas of the reform program: Madrid was willing to compromise its interests to appease the island's elite and sustain the empire. ${ }^{32}$ In my endeavor, I contribute to the historiography of female religious orders in colonial Latin America, to the historiography of the colonial Church in Cuba, and also to that of the Bourbon Reforms. Due to a scarcity of secondary works on the history female religious in Cuba and on the effects Bourbon ecclesiastical reform on the island, this study is based largely on primary sources. While the Archivo General de Indias (AGI) contains only a limited number of materials on conventual reform in eighteenth century cuba, those

32 For discussion of flexibility as an essential component of the empire see John Leddy Phelan, "Authority and Flexibility in Spanish Imperial Bureaucracy," Administrative Science Quarterly 5 (1960): 47-65; For discussion of its application in Cuba see Kuethe, Crown, Military, and Society, and Kuethe and Inglis, "Absolutism and Enlightened Reform." 
materials allow me to trace the achievements and failures of conventual reform over four decades. Often I am forced to rely on secondary works which address female religious life in other areas of the Spanish empire. To the degree possible, I rely on the letters that the nuns of santa Clara wrote to the Crown to shed light on the detrimental social impacts of Bourbon conventual reform. 
CHAPTER II

A HISTORY OF EAILED REFORMS

The pre-reform Observant Franciscan community of Santa Clara was one of three female communities in late eighteenth-century Havana. The other two were the Recollect Dominican community of Santa Catalina de Sena and the Discalced Carmelite community of Santa Teresa de Jesús. Not only the largest, wealthiest, and most prestigious in Havana, the Observant Franciscan community was also one of the city's greatest sources of patronage and the only female convent not under diocesan jurisdiction. Although founded in accordance with a 1632 license requiring that any convent founded in Havana be subject to diocesan authority and not to any regular order, Santa Clara always had been under Eranciscan jurisdiction. The 1632 license conflicted with Santa Clara's Constitutions, which required that Franciscan nuns be under the jurisdiction of their Eranciscan brethren. Governor Luna Sarmiento provisionally settled the matter at the convent's founding in 1644 by placing the nuns 
under Franciscan authority. A cédula of March 7, 1646 subsequently affirmed his decision. ${ }^{33}$

The combined populations of Santa Catalina and Santa Teresa, which included lay sisters as well as nuns, barely approached half of Santa Clara's religious population, which was comprised exclusively of more than 100 nuns of the black veil. ${ }^{34}$ With Santa Clara's 100-plus servants and tens of lay protégés and retirees figured into the

33 Fernández, El Obispo Compostela, 51; For a detailed discussion of the conflict between regular and secular jurisdiction see Testé, Historia eclesiástica, book 3, vol. 2, pt. 1, 108-114.

34 In 1782 Maria de Espiritu Santo, the prioress of Santa Catalina, reported to José de Gálvez that her community's population was comprised of twenty-two nuns and eight lay sisters (AGI, SD 1424, Maria de Espiritu Santo to José de Gálvez, June 30, 1782): Fernando Fernández Escobio says that Santa Teresa was comprised of twenty-one nuns and three lay sisters in "the middle of the eighteenth century" (Fernández Escobio, "El Obispo Compostela, 54): Manuel P. Maza reports that near the end of the episcopacy of Pedro Agustin Morell de Santa Cruz (1753-1768), Havana, a city of 75,518 residents, was teeming with religious: "118 Eranciscans, 59 Dominicans, 55 Augustinians, 39 hospitalarios, 32 Mercedarians, 20 Bethlemites, and 9 of the oratory...108 of Saint Claire, 27 Catalinas, 21 Carmelites and some 45 cofradias and lay associations" (Manuel P. Maza, "The Cuban Church: True Struggles and False Dilemmas: The Historical Characteristics of the Cuban Catholic Church and their impact on the 1959-1960 Episcopal Documents" (M.A. Thesis, Georgetown University, 1982), 26-27). 
equation, the convent's total population exceeded 250 , which was more than four times the combined populations of Santa Catalina and Santa Teresa, neither of which permitted secular females of any sort to live in the cloister. ${ }^{35}$ However, Santa Clara's population was Iarge only by comparison to other convents in Havana. In colonial centers, the population of convents could be much larger. In Lima, for example, the Convent of La Concepción had 318 nuns and 723 slaves, servants, infants, protégés, and retirees in 1700. About the same time, Santa Clara of Santiago had more than 400 professed nuns. ${ }^{36}$

All three female religious communities in Havana enjoyed heightened prestige in the latter half of the eighteenth century, as a growing elite population looked to convents to shelter its daughters, but none enjoyed

35 AGI, SD 1414, Testimonio of Pedro de Hechavarría, October 17, 1776; AGI, SD 1424, Maria de Espiritu Santo to José de Gálvez, June 30, 1782.

36 Rubén Vargas Ugarte, S.J., El monasterio de La Concepción de la Ciudad de los Reyes (Lima: Talleres Gráficos de la Editorial Lumen, 1942), 6; Lavrin, "Female Religious," 175; Martín, Daughters, 81-82, 173. 
more than Santa Clara. ${ }^{37}$ The prestige of the Observant Franciscan community far outdistanced its competitors, with the community drawing its members from the highest rungs of elite society. Like so many convents, Santa Clara was a bastion of the "socio-ethnic elite." A mixed-race female was excluaed by the stigma of her birth and a poor white female by the size of the dowry required (which surpassed 2,000 pesos). ${ }^{39}$ In contrast to the mainland, which had large Indian and mestizo populations, Cuba's ethnic mix included no Indians but large numbers of

${ }^{37}$ Huerta, "El monacato femenino," 495, 500.

38 Lavrin, "Women and Religion," 44; While in-depth studies on the social backgrounds of nuns are scarce, Lavrin suggests that nuns in colonial Mexico generally came from "comfortable surroundings," but not from the ranks of the nobility. Rather, their fathers were leading bureaucrats, wealthy merchants, landowners, and highranking military officers. Quite often they were orphaned or simply could not marry at their station in life (Lavrin, "Female Religious," 168, 179): Donald Gibbs, in an analysis of the social makeup of the convents of Cuzco, finds that the social status of nuns there ran the gamut, from poor orphans to the daughters of noblemen (Gibbs, "Cuzco," 64).

39 Lavrin, "Women and Religion," 44; Fernández, El Obispo Compostela, 50; In Mexico dowries ranged between 1,000 and 2,000 pesos in the sixteenth and seventeenthcentury Mexico, 3,000 in the eighteenth, and as much as 4,000 pesos by the end of the colonial period (Lavrin "Female Religious," 177). The dowry at Santa Clara grew to 2,750 pesos by 1837 . 
blacks and mulatos. In 1774, for example, Cuba's population was comprised of 96,440 whites, 30,847 free people of color, and 44,333 slaves. By 1791 there were 153,559 whites, 54,151 free people of color, and 64,590 slaves. ${ }^{40}$ While convents in Mexico and other colonial centers often went to great lengths to block the admission of the mestiza, Santa clara screened out the mulata. The Clares of Havana looked with suspicion upon illegitimate offspring and orphans if both of their parents were not known. ${ }^{41}$ In any case, there were more than enough eligible white women to ensure that Santa Clara never lacked qualified candidates. ${ }^{42}$

As the only "convento grande" in the city, Santa Clara held the dubious distinction of being the least disciplined. ${ }^{43}$ The Clares of Havana, like nuns in conventos grandes elsewhere, generally lived a communal

40 Pérez, Cuba: Between Reform and Revolution, 63.

41 AGI, Ultramar 396, Expediente of María de la Asensión Valdés, April 12, 1815.

42 Lavrin, "Women and Religion," 44.

43 For a detailed discussion of life in a convento grande see Martin, Daughters, 207. 
social and religious life but not a communal economic life. Due in large part to the inadequacy of communal resources, the nuns relied heavily on supplements provided by their wealthy families and/or benefactors.

Like elsewhere in the Spanish Empire, the problem of relaxed monastic discipline at Santa Clara of Havana was no eighteenth-century phenomenon. In fact, monastic discipline at the convent had become "very relaxed," in the opinion of its Franciscan superiors, within a quarter century of the convent's founding in 1644. This led Franciscan Commissary General Zamora, in 1671, to issue the first of many patentes de reforma lofficial orders to reform).$^{44}$ In issuing the patente, zamora called upon the nuns to live according to their Rules and Constitutions. Only one year later, after witnessing "enormous transgressions" during a visita to the convent, the Franciscan provincial in Havana issued a patente de reforma of his own. Chief among the provincial's concerns in 1672 was the community's failure to observe the vow of poverty. A decade later, in 1682, Commissary General

44 The commissary general was head of the order, resident in Spain and attendant on the King and the Council of the Indies. 
Zamora ordered an end to all irregular practices at the convent. Of particular concern on this occasion was the very common practice of selling sweets, cloth, and other items from the tornos. ${ }^{45}$ Although convents throughout the empire allowed the sale of sweets and other items to raise money for the community or for the individual nuns, the convent's superiors frowned on the practice. Zamora's successor, Commissary General Julián Chumillas, kept pressure on the nuns to reform. In accordance with a 1688 cédula, Chumillas ordered the expulsion of all servants from Santa Clara, prohibited the sale of items from the tornos, barred families of the nuns from assuming proprietary rights over the convent's cells, and ordered that the costs associated with professing at the convent be limited. ${ }^{46}$ The fact that the orders had royal sanction

45 AGI, SD 1134, Plácido de Pinedo to the Council of the Indies, January 22, 1764, summarized in the consulta of June 20, 1764; Lavrin "Women and Religion," 48.

46 AGI, SD 1134, Plácido de Pinedo to the Council of the Indies, January 22, 1764, summarized in the consulta of June 20, 1764; Fernández Escobio says that a royal cédula arrived in Havana in 1689 ordering the expulsion of 250 "slaves" and adds that a few months after the cédula arrived the guardian of the convent of San Francisco, Marcos de Sotolongo, found 112 slaves living at Santa clara. He notes that after 1700, the number of slaves at Santa Clara was not supposed to exceed fifty (Fernández Escobio, El Obispo Compostela, 52). 
made seemingly little difference to the nuns, evidenced by the fact that the Crown felt compelled to have Chumilla's successor, Commissary General Antonio de Cardona, re-issue the same orders during his term in office. Finally, in 1696 Cardona prohibited another common practice: that of allowing secular women to Iive in the cloister. ${ }^{47}$ However, in the tumult of the war of Spanish Succession (1701-1713), the Crown became preoccupied with other matters, momentum was lost, and any hope of reforming Santa Clara faded.

Although Santa Clara managed to escape the attention of the Crown for a century after 1696, Eranciscan prelates continued to prod the community to reform. In 1711, for example, Commissary General Pedro Alvarez de Toledo ordered the nuns to establish a uniform regimen of eating and dressing. That same year, the provincial in Havana ordered an end to all extravagances at the convent, such as the customary use of ornamental habits and jewelry. In 1718 Commissary General José Sanz issued a patente de reforma aimed at correcting "various abuses" at the

47 AGI, SD 1134, Plácido de Pinedo to the Council of the Indies, January 22, 1764, summarized in the consulta of June $20,1764$. 
convent and threatened any nun who failed to obey with excommunication. However, Sanz found it necessary to repeat his order and his threats of punishment only one year later. Still, nothing happened, leading Commissary General Juan de Soto, in 1723, to re-issue Sanz's patentes. Soto's successor, Commissary General Domingo de Losada, did the same in 1730 and, at the same time, called upon the nuns to obey the orders of Fernando Alonso González, Commissary General of New Spain, which prohibited any deviation from the monastic regimen or innovation in the mode of dress. ${ }^{48}$

Not be discouraged by the failure of his predecessors to reform Santa Clara, Commissary General Matias de Velasco stepped up efforts to bring the community into compliance with its Rules and Constitutions in the mideighteenth century. In 1746 Velasco ordered the provincial in Havana, Pedro Ximénez, to put an end to all irregular practices at the convent. One of these practices had been exposed by Bishop Laso de la Vega in a series of letters he wrote to Velasco between 1742 and 1745. In his letters, the bishop described how

48 Ibid. 
indecently-clad "mulata servants" carried on conversations "day and night" from the eight windows of Santa clara that looked out onto the street. ${ }^{49}$ Many more infractions were exposed by the provincial, Ximénez, during a visita he made to the convent. ${ }^{50}$ In the intense Havana heat, the nuns were permitted to forgo their habits in private areas of the convent but were required to don them, along with their veils, when venturing into public areas. However, Ximénez found that some nuns regularly ventured into public areas in "low cut, indecent dress" where they ran the risk of encountering secular persons, such as doctors, bleeders, surgeons, and craftsman. The practice spilled over into the spiritual exercises as well: some nuns went to the coro without their habits to say the rosary. ${ }^{51}$ In

49 The servant class at Santa clara was a mixture of black slaves, mulatas, poor whites, and, in the late eighteenth century, elite young girls who entered the convent as servants with the hope of proceeding to the novitiate.

50 The date of the visita is not given.

51 Ibid. The church was attached to the cloister. The nuns entered the coro to pray or hear the mass. From this room, which was separated from the Church by a grille, curtain, or both, the nuns could see the main altar and hear the mass. The nuns received communion through an opening in the coro's grille (For a description of the function of each room see Lavrin, "Female 
general, the provincial found that obligatory spiritual and temporal exercises were poorly attended; Ximénez concluded that only young nuns and an occasional older nun "with a particular devotion" participated in silent prayer, recited the Holy offices (e.g., matins), or took their meals in the refectory. ${ }^{52}$ However, when Ximénez attempted to put an end to these and other transgressions (such as the continued practice of selling items from the tornos), the nuns appealed to the crown for protection. Commissary General Velasco countered by pointing out that the nuns appealed to the crown on each occasion reform was attempted with claims that their superiors had introduced novel measures, disturbing the peace that previous superiors had maintained. The Crown agreed, siding with Velasco in the dispute. ${ }^{53}$

Religious," 173). Large convents, like Santa Clara, had an upper and lower coro (AGI, SD 1418, Diego José Navarro to the Council of the Indies, September 6, 1778).

52 AGI, SD 1134, Plácido de Pinedo to the Council of the Indies, January 22, 1764, summarized in the consulta of June 20, 1764 .

53 Ibid. 
With renewed confidence, Velasco ordered Ximénez to issue a far-reaching patente de reforma in 1747. Comprised of eighteen points, the patente was intended to "moderate and reform" Santa clara. The nuns, troubled by an order in the patente which mandated iron grilles for the convent's two locutorios and additional wooden grilles for its eight windows that looked out onto the street, asked the commissary general to forgive them for their resistance and appealed to the governor for protection. ${ }^{54}$ Angered by the community's insubordination, Velasco ordered the sisters to obey Ximenez's patente de reforma within fifteen days or face discipline and possible excommunication. Their resolve weakened by the crown's decision to back the commissary general a few years earlier, the nuns reluctantly complied.

54 Ibid. The locutorios were the rooms where friends and relatives would come to visit the nuns, residents to borrow money, and priests to hear confessions. In the discalced (which means "shoeless" or sandeled") orders and other austere orders, curtains hung in the locutorios to shield the nuns (Lavrin, "Female Religious," 174; Luis Martin, Daughters, 176). The decision to put second grilles of wood in the windows of the outer cells was a response to the complaints lodged by the Bishop Laso de la Vega between 1742 and 1745 (AGI, SD 1134, Plácido de Pinedo to the Council of the Indies, January 22, 1764, summarized in the consulta of June 20,1764 ). 
Having gained the upper hand, Velasco did not relent in his effort to reform Santa clara. In 1753 he enforced an ecclesiastical law which required that the admission of all protégés (educandas) and retirees ( subject to papal approval or of "whomever had the authority" (the latter, an apparent concession to the Crown). 55 Seven years later, in a 1760 pastoral letter, the commissary general ordered the nuns to refrain from singing at the grille of the coro without first covering their faces with veils or closing the curtain which separated the coro from the church. At the same time he admonished the sisters to expel all of their personal servants and to receive lay sisters (legas) in their place, something the nuns refused to do. ${ }^{56}$ However, it

55 Ibid. Protégés (educandas) were girls between the ages of six and twelve who entered the convent to be educated and groomed for the novitiate. Retirees (seglaras) were young girls or women who retired to the convent with no intention of taking the habit.

56 Ibid. The nuns did not begin dismissing servants until 1783 and had not complied with the order to admit lay sisters (legas) of 1808. A lay sister, or a nun of the white veil, took religious vows but was of a lower status than a nun of the black veil. She usually performed the manual labor in the convent, such as cleaning, cooking, and laundering. Often a lay sister came from an impoverished family and relied on a benefactor to provide a dowry. The dowry of a lay sister was considerably less than that of a nun of the black 
was a subsequent order of Velasco, one to install sheets of dense lattice work over the iron grilles of the coro, that most angered the sisters. Intended to prevent the disturbances caused when "signs and courtesies" passed between the nuns in the coro and their families and friends in the church during worship services, this measure, combined with the earlier one to put iron grilles with prongs ("sembradas de puas") in the locutorios, sparked a heated quarrel between the nuns and their superiors. ${ }^{57}$ When the nuns appealed to Madrid in April of 1761 for protection, they unwittingly gave the crown a justification for re-involving itself in the affairs of their community. ${ }^{58}$

veil. She did not vote in elections and could not hold office. But she was bound by religious vows and had to abide by the rules of the convent (Lavrin, "Female Religious," 177; Martín, Daughters, 184-185).

57 AGI, SD 1134, Plácido de Pinedo to the Council of the Indies, January 22, 1764, summarized in the consulta of June 20, 1764; AGI, SD 1136, Manuel Josef Crespo to Plácido de Pinedo, August 1, 1765, summarized in the consulta of January 7,1768 .

58 AGI, SD 1134 and 1136, The officers of Santa Clara to the Crown, April 17, 1761, summarized in consultas of June 20, 1764 and January 7, 1768. Although unnamed in either of the consultas, the officers included the abbess, vicaria de la casa (the second in command) difinidoras (powerful nuns who formed the abbess' cabinet), and the 
The experiences of would-be reformers in Havana to the mid-eighteenth century were by no means unique. Reformers in Mexico encountered similar resistance when they tried to reform the irregular practices of nuns under their jurisdiction. For example, in 1667 Mateo de Heredia, a Franciscan provincial, tried unsuccessfully to limit the number of servants in convents under his jurisdiction. Six years later, in 1673, the Crown joined in the chorus calling for reform on the Spanish American mainland by ordering female communities to limit their servant populations to that permitted by their Rules; however, transgressions of this variety continued to confound reformers on the mainland for more than a century after 1673. Nonetheless, between 1712 and 1728, the Archbishop of Mexico, Aguiar y Ceijas did wage a successful battle against the use of ornamental habits, jewelry, and other extravagances. Still, other irregularities persisted to confound reformers. Eranciscan prelates, between 1727 and 1750, complained variously of the excessive number of protégés, retirees,

depositaria general (a nun who administered the finances of the community along with the male secular mayordomo (manager). 
and servants in convents under their jurisdiction; the tendency of the nuns to spend lavishly on feast days and other celebrations and on the ornamentation of their churches; the unrestricted admission of male workers into the cloister; the mismanagement of communal finances; the excessive personal expenses of the nuns; the sale of merchandise from the tornos; the practice of choir nuns begging alms; and the high costs associated with holding office at the convent. Finally, in 1754 the first conde de Revillagigedo criticized the nuns for burdening their families with unnecessary expenses. ${ }^{59}$

In Mexico and Cuba alike, Iong-practiced abuses were passed off as customs. Nuns saw no contradiction between their daily routines and the Constitutions and Rules under which they took their vows. ${ }^{60}$ when polled, the overwhelming majority of nuns at Santa Clara of Havana claimed to be well versed in the content of their Rules and Constitutions. ${ }^{61}$ With irregular practices so much the

\footnotetext{
59 Lavrin, "Ecclesiastical Reform," 183.

60 Ibid., 184

61 Ninety-two nuns interviewed by Manuel Josef Crespo in a 1765 visita to Santa Clara claimed to be well instructed in the Rules and Constitutions of their order
} 
fabric of female communities, reformers in Mexico and Cuba made little headway without the benefit of royal sanction. Reform in Cuba received royal sanction in February of 1768.

(AGI, SD 1136, Manuel Josef Crespo to Plácido Pinedo, summarized in the consulta of January 7, 1768). 
CHAPTER III

THE REGLAMENTO OF 1768

Following a pattern established elsewhere in the empire, the crown's decision to re-involve itself in the affairs of Santa Clara was precipitated by a quarrel between female religious and their regular male superiors and justified by a negative report originating with a secular prelate. In the early $1760^{\prime} \mathrm{s}$ the Crown was drawn into a dispute between the community of Santa clara and its Franciscan superiors when the nuns appealed to Madrid for protection. In deliberating a resolution to the dispute, the Crown ordered the Bishop of Cuba, Pedro Agustin Morell de Santa Cruz (1753-1768), to report on the state of affairs at Santa clara. The bishop's scathing report on the administration of the convent opened the door to extensive reform proposals. Commissary General Plácido de Pinedo formulated these into a reglamento (a set of rules and regulations), which was sanctioned by the Crown in Eebruary of 1768.

It was quite common in the colonial period for regular prelates to meddle in the affairs of a female community under their jurisdiction, and it was also quite common for a female community to request a transference to 
diocesan jurisdiction when the meddling became intolerable. ${ }^{62}$ Angered by what it perceived to be incessant interference on the part of its superiors, Santa Clara followed in this vein in 1761. On April 17 of that year, citing the recent decision of their superiors to place dense lattice work over the iron grilles of the convent's coro and an earlier decision, dating from about 1750, to put iron grilles with prongs (sembradas de puas) in its two locutorios, the officers of Santa Clara asked the Crown to either order the measures rescinded or else allow the community to transfer itself to diocesan jurisdiction. In support of their petition, the nuns cited the 1632 royal license under which their community was founded, which stipulated that any convent founded in Havana be subject to diocesan jurisdiction. ${ }^{63}$

The lattice work that shielded the coro was the more disturbing of the two measures because it aggravated overcrowded conditions. At the nuns' writing, there were

62 Lavrin, "Women and Religion," 48; and Martín, Daughters, 245-257.

63 AGI, SD 1134 and 1136, The officers of Santa Clara to the Crown, April 17, 1761, summarized in consultas of June 20, 1764 and January 7, 1768. 
110 nuns and an even greater number of servants living at Santa Clara, all of whom were required to attend mass daily. The dense lattice work exacerbated problems caused by a scarcity of masses (the officers of Santa Clara reported that only two were said daily), making it difficult for all in the community to attend mass and see the main altar. According to the officers, only those nuns fortunate to have a place on the front row of the coro could get near enough to the lattice work to peer through its tiny holes, leaving the majority of the nuns and all of the servants unable to see into the church. ${ }^{64}$

A resolution to the dispute was delayed by the seven Years War (1756-1763), during which Havana fell to British forces. When Bourbon officials began returning to Havana in late 1763, the Council of the Indies finally took up the matter of Santa Clara's grievances, requesting a report from the commissary general in January of 1764 . In response to the Council's inquiry, Commissary General Plácido de Pinedo, Velasco's successor, assured the tribunal that the disputed measures, like all previous

64 AGI, SD 1134, The officers of Santa Clara to the Crown, April 17, 1761, summarized in the consulta of June 20, 1764 . 
reform measures, had sufficient motive and were intended only to make the nuns comply with their Rules and Constitutions. Rather than dismiss the grievances outright, however, Pinedo proposed that they be investigated in a visita. The Council agreed but, ever cautious, requested a letter from the Bishop of Cuba, Pedro Agustín Morell de Santa Cruz. ${ }^{65}$

In the summer of 1765, Friar Manuel Joseph Crespo arrived at Santa Clara to conduct an interrogatory vista. During the course of his visita, Crespo investigated each of the claims, even probing the holes of the coro's lattice work with his own finger. Because his finger could pass through most of them, he determined that they were of regulation size. Crespo also determined that four, not two, masses were said daily, permitting all of the nuns and servants at the convent to attend mass and see the main altar. ${ }^{66}$ Despite the addition of hated

65 AGI, SD 1136, Consulta, January 7, 1768.

66 AGI, SD 1136, Plácido de Pinedo to the Council of the Indies, November 30,1766 , summarized in the consulta of January 7, 1768; The bishop had concluded independently of the visitador that three masses were scheduled daily but that only two were said with any regularity: that of the vicar and another of his assistant (AGI, SD 1136, Pedro Agustin Morell de Santa Cruz to the Council of the 
planchas de hierro in the locutorios, Crespo found that the nuns still were not in perfect compliance with their Constitutions, which required that they both wear veils and be shielded by black curtains when conversing with secular persons. Although the nuns wore veils, they had removed the obligatory black curtains from the interior of the locutorios' grilles. The visitador associated no ill effects with their removal. ${ }^{67}$ Acting on Pinedo's orders, Crespo interviewed ninety-two nuns in an effort to determine if the opinions expressed by the officers in their 1761 letter to the crown had wide support. On the basis of the interviews, the visitador determined that they were not. Rather, he concluded in a August 1, 1765 report to the commissary general (a report that Pinedo forwarded to the Council) that the community was content under Franciscan jurisdiction, well instructed in its Rules and Constitutions, and in fairly good discipline. ${ }^{68}$

Indies, May 31, 1765, summarized in the consulta of January 7,1768 ).

67 AGI, SD 1136, Plácido de Pinedo to the Council of the Indies, November 30,1766 , summarized in the consulta of January 7,1768 .

68 Although Plácido de Pinedo did not elude to the specifics of the reformed practices in his letter to the 
Earlier, Bishop Morell de Santa Cruz had reached a far different conclusion in his assessment of the situation at Santa Clara, which focused on the financial abuses perpetrated under the Franciscan administration of the convent. In a report dated May 31, 1765, the bishop portrayed the observant Eranciscan community as undisciplined, as a community being led astray by its Franciscan superiors. The most serious charges leveled by the diocesan prelate were that a Eranciscan superintendente served as mayordomo of the convent and that this individual, along with two nun contadoras, invested the convent's censos (endowment derived from dowries and other contributions) without the provincial's oversight, which was required by the Constitutions. Bishop Santiago José de Hechavarría, the successor of Morell de Santa Cruz, claimed that the practice had resulted in a loss of more than 100,000 pesos from the censos and necessitated the community paying a "hefty salary" to the Eranciscan superintendente: for his services, the superintendente received five reales a day

Council, the visitador referred to the fact that the nuns had ceased to use ornamental habits and consume rich foods (Ibid.) 
for food and ten pesos monthly and fifty annually for

"habits" and an income from two chaplaincies

(capellanias). And all of this was in addition to what he received from paid masses said at the nuns' request. ${ }^{69}$

Cloistered communities, like Santa Clara, depended on the honesty of capable administrators, because an investment property of poor quality could prove unprofitable for the lessor. In turn, the lessor would have difficulty meeting his annual payments, which amounted to five percent of the property's value. ${ }^{70} \mathrm{~A}$ mayordomo (manager) generally administered a community's external financial affairs. He oversaw its rural and urban properties and collected rents from tenants. With such important duties, he tended to be the highest paid

69 AGI, SD 1136, Pedro Agustín Morell de Santa Cruz to the Council of the Indies, May 31, 1765, summarized in the consulta of January 7, 1768; A capellania entailed saying memorial masses and performing other spiritual duties (John Frederich Schwaller, Origins of Church Wealth in Mexico, Ecclesiastical Revenues and Church Finances, 1523-1600 (Albuquerque: University of New Mexico, 1985), 113 .

70 Lavrin, "Female Religious," 180-182. 
secular employee of the convent. Internal administration was left to the nun contadoras. ${ }^{71}$

A number of lesser offenses also had come to light as a result of the bishop's report. The nuns of Santa Clara spent lavishly to commemorate the election of a provincial, his arrival for a visita, or to mark an occasion when a high-ranking priest said mass on a special feast day. Afforded a tremendous amount of autonomy in private cells that were accessed by private stairways,

71 Lavrin, "Colonial Woman in Mexico," 44; Martín, Daughters, 269-270; Over time, convents in Mexico turned to urban investments (i.e., large houses occupied by titled nobility, high-level bureaucrats, or rich merchants; multiple-tenant dwellings; shops; and baths) (Lavrin, "Eemale Religious," 182). In contrast, Santa Clara appears to have continued to invest heavily in rural properties, a reflection of the pull of the sugar boom. In the nineteenth century, for example, Santa Clara owned twenty sugar plantations (Hugh Thomas, Cuba: The Pursuit of Freedom (London: Eyre and Spottiswoode, 1971), 82); In 1766 Santa Clara's rents were quite substantial. According to Juan Manuel de Aguirre, a past mayordomo of the convent, 289 nuns had entered Santa Clara since its founding in 1644. Aguirre estimated there dowry contributions to total 785,910 . Less 100,000 pesos in losses due to poor investments, plus 52,000 pesos conceded by the crown in tierras realengas, the convent's capital amounted to 737,910 pesos, which should have yielded the community 36,875 pesos annually (AGI, SD 1136, Pedro Agustin Morell de Santa Cruz to the Council of the Indies, May 31, 1765, summarized in the consulta of January 7, 1768). 
some nuns had adopted the custom of receiving female visitors during periods of bereavement, serving sweets and exchanging news and gossip items. ${ }^{72}$ Finally, at Santa Clara aspiring novices were required to deposit a 300 peso propina (an amount over the required dowry) before the community even would convene to consider her candidacy. ${ }^{73}$

After reviewing the reports of the Franciscan visitador and the bishop, the fiscal of the Council labeled the petition of Santa Clara's officers "disingenuous," accusing the nuns of having neglected to mention several "disorders" subsequently exposed by Crespo and Morell de Santa Cruz. On this basis, he recommended that the convent remain under jurisdiction of its

72 AGI, SD 1136, Pedro Agustín Morell de Santa Cruz to the Council of the Indies, May 31, 1768, summarized in the consulta of January 7, 1768; Lavrin says it was not at all uncommon for gossip and political, social, and even fashion news to penetrate a convent's walls (Lavrin, "Women and Religion," 48).

73 The bishop solution to limiting the costs associated with one's profession at Santa Clara was extreme in that he not only wanted to abolish the propina but wanted to dispense with the required dowry altogether for poor girls legacies of the convent (AGI, SD 1136, Pedro Agustin Morell de Santa Cruz to the Council of the Indies, May 31, 1768, summarized in the consulta of January 7, 1768). 
Franciscan superiors. Still, the fiscal was critical of those superiors for failing to reform several practices which he said were "diametrically opposed" to the Rules and Constitutions of the order. Of particular concern to the official were the financial abuses exposed by the bishop in his May 1765 report. ${ }^{74}$

74 He criticized the friars for failing to limit the number of nuns at Santa Clara to what the community's rents and alms (limosnas) could support; allowing a Franciscan superintendente to serve as mayordomo; allowing the superintendente and two nun contadoras to invest the community's censos without supervision; permitting the community to administer to its members, as well as to the priests who assisted them, with money rather than rations in kind; tolerating the nuns' lavish spending on celebrations of which the friars were often the beneficiaries, such as those staged to commemorate a provincial's election or his arrival for a visita;

tolerating the nuns' tendency to discharge their duties with "extraordinary splendor" and then shifting the high costs associated with the extravagances to their families; recognizing elite families as proprietors of the convent's cells, precluding either the community or the abbess from distributing the cells and also effectively making some nuns proprietors themselves; allowing the nuns, during periods of bereavement, to receive visitors and indulge in conversation and partake of sweets and refreshments sometimes for entire evenings; and, finally, permitting the nuns to require of a candidate to the novitiate a nonrefundable 300-peso fee, an amount which "considerably exceeded" that set by Velasco (AGI, SD 1136, Respuesta of the fiscal, August 31, 1766, attached to the consulta of January 7, 1768). 
For no apparent reason, in the autumn of 1766, the Council of the Indies chose to maintain silence about the bishop's report. Not following upon the fiscal's respuesta, the Council ordered Pinedo only to respond to the irregularities exposed by Crespo during his visita. On November 30, 1766, Commissary General Pinedo told the Council what he planned to do. Content that Crespo's visita had revealed no "substantial contravention" of the Order's Rules and Constitutions, Pinedo admitted, nonetheless, that some of Crespo's findings concerned him. of particular concern were the revelations that very few nuns ate their meals in the refectory; that those nuns who ran the sacristy, infirmary, garden, kitchen and other parts of the convent did not receive adequate communal support to cover the costs associated with their offices; that a large number of secular females continued to live at the convent; and that elite families continued to assume proprietary rights over the convent's cells. ${ }^{75}$ The nuns of Santa Clara were required by their Constitutions to eat lunch and supper in the refectory,

${ }^{75} \mathrm{AGI}, \mathrm{SD} 1136$, Plácido Pinedo to the Council of the Indies, November 30,1766 , summarized in the consulta of January 7, 1768 . 
"from the communal pot, contenting themselves with however much or little they were given."76 only the abbess could excuse an infirm nun from the twice-daily trek to the refectory. An excused nun had to eat in the infirmary, never in her own cell. The constitutions sanctioned a two-month suspension for the abbess who was remiss in enforcing the measure. Nonetheless, healthy nuns regularly ate in their cells at Santa Clara. Although some, if not most, of the cells at the convent probably were equipped with kitchens, in which servants could have fixed meals, it appears that the custom at the convent was to have servants bring meals from the nuns' familial houses in the city. ${ }^{77}$ The commissary general recommended a strict adherence to the Order's Constitutions as a means of ending the practice. ${ }^{78}$

76 Ibid.

77 Ibid. AGI, SD 1136, Pedro Agustin Morell de Santa Cruz to the Council of the Indies, May 31, 1765, summarized in the consulta of January 7, 1768 .

78 AGI, SD 1136, Plácido to Pinedo to the Council of the Indies, November 30, 1766, summarized in the consulta of January 7,1768 . 
The Constitutions also mandated that the nuns who ran the refectory, kitchen, infirmary, garden, and other parts of the convent receive adequate communal funding to cover the costs associated with their offices. Yet these officials frequently used private resources to discharge their duties, supplementing inadequate communal contributions with money provided by family members or other benefactors. ${ }^{79}$ Pinedo suggested that the community employ constitutionally-mandated measures to remedy such shortfalls. In particular, he recommended that the abbess visit the offices of the convent on occasion to familiarize herself with the functions and needs of each; that the convent's administration create a budget to more effectively allocate communal resources; and that the community limit its population to what rents and alms could support, exercising its constitutional right to collect a double dowry from supernumerary entrants. ${ }^{80}$

79 Ibid. In his May 1765 report, Bishop Morell de Santa Cruz charged that parents, relatives, and benefactors often supported the nuns "far beyond what their means allowed (AGI, SD 1136, Pedro Agustin Morell de Santa Cruz to the Council of the Indies, May 31, 1765, summarized in the consulta of January 7, 1768).

80 AGI, SD 1136, Plácido de Pinedo to the Council of the Indies, November 30, 1766, summarized in the consulta of January 7, 1768. 
Although Santa Clara's large secular population consumed little, if any, of its communal resources, the practice of housing large numbers of servants, retirees, and protégés was frowned upon by the crown and reformers alike. One of the negative consequences often associated with the admission of servants, retirees, and protégés was that it facilitated almost continuous contact between nuns and secular females. This was a particular concern at Santa Clara because the convent had no separate area in which to house secular females. ${ }^{81}$ Another factor was that such admissions contributed greatly to chronic overcrowding at the convent. ${ }^{82}$ Because Santa Clara's Constitutions sanctioned only one communal servant for every ten nuns and prohibited the use of personal servants, except with papal dispensation, strict observance should have limited the number of servants at the convent to fewer than ten and, yet, the Franciscan

${ }^{81}$ AGI, SD 1491, Expediente concerning the difficulties that the religious of Santa Clara, Santa Teresa, and Santa Catalina of the city of Havana faced in trying to execute the cédula of December 26, 1795 (which concerned the admission of educandas in the convents), November 6, 1797.

82 AGI, Ultramar 396, Manuel de la vega to the Council of the Indies, November 6, 1783. 
nuns maintained more than 100 servants with their personal resources. ${ }^{83}$ Liberal papal policy with regard to the admission of servants and non-sanctioned admissions were to blame for the unchecked growth.

The Constitutions also allowed for the admission of retirees and protégés under two conditions: if there was "urgent cause" or if the aspirant was of particularly "great character." 84 As in the case of servants, papal dispensation was a pre-requisite to the admission of retirees and protégés. Nonetheless, subjectivity in the admission criteria for this non-servant class and nonsanctioned admissions had resulted in dozens of secular women and girls living at Santa Clara.

To curb the large servant population, Pinedo recommended that the nuns adhere to the restrictions contained in their constitutions. With regard to the nonservant secular population, he supported a proposal by

93 AGI, SD 1134, The officers of Santa Clara to the Crown, April 17, 1761, summarized in the consulta of June 20, 1764 .

84 AGI, SD 1136, Plácido de Pinedo to the Council of the Indies, November 30, 1766, summarized in the consulta of January 7,1768 . 
Crespo to Iimit the combined total of retirees and protégés to fifteen. ${ }^{85}$

Einally, in accordance with the order's Constitutions, when a nun died no member of the community, much less anyone outside of the convent, could claim anything left by the deceased, especially not her cell. After consulting with the abbess and the discretas, the provincial could issue a license to assign the deceased nun's cell. Everything else became communal property, to be shared by all. The provincial also could grant a license for the construction of a new cell or renovation of an older one. However, elite families had come to assume that a license allowing for the construction or renovation of a cell conveyed actual ownership. After the initial investment, a family customarily treated a cell as its own, passing it from one generation to the next. Although quite common in the empire, the practice had its negative consequences: young nuns, just removed from the

85 Ibid. AGI, Ultramar 365, Royal Order, May 10, 1794. 
novitiate, often occupied the best cells and merited nuns the least comfortable ones. ${ }^{86}$

The commissary general insisted that the intention of the provincial's license had not been to convey ownership and labeled the situation--one in which the abbess and discretas had no say in the distribution of some cells and in which some members of the community lived as property owners--an "enormous and intolerable absurdity." However, recognizing the delicacy of the situation, Pinedo recommended that elite families be reimbursed for the costs they had incurred in the construction or refurbishment of the cells. Until the costs of such a reimbursement could be tallied, he proposed reducing the number of nuns at Santa Clara to ninety, thereafter allowing the number to grow to 100, as Crespo had suggested. ${ }^{87}$

86 AGI, SD 1136, Plácido de Pinedo to the Council of the Indies, November 30, 1766, summarized in the consulta of January 7, 1768; Lavrin, "Female Religious," 174.

87 AGI, SD 1136, Plácido de Pinedo to the Council of the Indies, November 30, 1766, summarized in the consulta of January 7,1768 . 
After reviewing the Pinedo's reform proposals, the Council of the Indies did not order their implementation immediately. Instead, the tribunal disclosed to the commissary general the charges contained in the bishop's report of May 31, 1765, which were more than two years old by then. On August 1, 1767 the Council instructed the commissary general to propose remedies for the irregularities revealed in the bishop's report and to incorporate those remedies, as well as his own formulated in response to Crespo's findings, into a reglamento (see Appendix A). ${ }^{88}$ The Council suggested what those remedies should be, attaching to its letter copies of two respuestas of its fiscals, both of which called for the removal of the Eranciscan superintendente and a strict adherence to the Order's Rules and Constitutions. ${ }^{89}$ In responding to the Council's request, Pinedo set the tone of four decades of reform at Santa clara.

In formulating the reglamento, the commissary general incorporated his own proposals almost verbatim and

88 AGI, SD 1136, Consulta, January 7, 1768.

89 AGI, SD 1136, Respuestas of the fiscal, August 31, 1766 and February 13, 1767, both attached to the consulta of January 7,1768 . 
attempted to remedy the bishop's charges in accordance with fiscals' recommendations. Pinedo disputed the bishop's most serious charge: that a Franciscan superintendente served as mayordomo at Santa Clara. He argued that the superintendente's duties were distinct from those of the mayordomo and that his actions were "pure" and sanctioned by the Order's Constitutions. Nonetheless, to remove any semblance of impropriety and to appease the Council, Pinedo abolished the office, citing the high costs associated with it. At the same time the commissary general prohibited any Franciscan from serving as mayordomo of the convent; ordered the vicar, abbess, and discretas to participate in all investment decisions; and required the provincial's signature on all bills of sale.

Pinedo, likewise, disputed the bishop's conclusion that the holes in the coro's lattice work were too small, reiterating Crespo's conclusion that the holes matched the specifications stipulated in the order's Rules. Nonetheless, he ordered that the holes in the coro's lattice work, as well as those in the planchas de hierro of the two locutorios, be made larger to match the specifications established in the Order's Constitutions, 
which differed from those stipulated in the Rules. ${ }^{90} \mathrm{~A}$ decade later, however, the enclosure measures were still an issue with the nuns. ${ }^{91}$

Pinedo did not dispute the bishop's other charges and remedied them accordingly. He banned the sale of sweets and other items from the tornos and the provision of meals for the convent's superiors and high-ranking priests who said mass on special feast days. The abbess who allowed meals to be served to a friar risked a three-month suspension from office. A nun caught actually serving a meal faced a more interesting punishment: she was "to eat under the table for an entire month and admit [her] fault before the abbess, the community, and the priests." An offending friar risked removal from office and exposed himself to other penalties left to the discretion of the

90 AGI, SD 1136, Reglamento, November 23, 1767, quoted in the consulta of January $7,1768$.

91 In 1778, for example, Governor Diego Josef Navarro reported that the size of the holes in the coro's lattice work made it "impossible to register anything in the dim light" and, at the same time, reported that the openings in the locutorios' grilles were narrower than required in the Constitutions (AGI, SD 1418, Diego Jose Navarro to the Council of the Indies, september 6, 1778, attached to the Eebruary 20, 1778 expediente of the Marqués de la Torre). 
commissariat. Pinedo also prohibited the "worldly etiquette" exhibited by the nuns during periods of bereavement, threatening an offending nun with deprivation of voz activa and voz pasiva (i.e., the right to vote in communal elections and hold office); banned the practice of receiving propinas before voting on an aspirant's candidacy, under the threat of constitutionally sanctioned punishments and others left to the discretion of the commissariat; and limited the number of confessors at Santa Clara to two, the vicar and his assistant. ${ }^{92}$ One of Pinedo's primary objectives in formulating the reglamento was to reestablish communal life at Santa Clara, and he realized that to achieve this goal it was imperative to reduce Santa Clara's religious population. Therefore, his reglamento required that the difinitorio of the province (advisory panel to the provincial) set a desirable population for Santa Clara every ten years. The difinitorio's determination was to be based on a budget created by the provincial, who was expected to rely on the assistance of the vicar of the convent, the abbess, and

92 AGI, SD 1136, Reglamento, November 23, 1767, quoted in the consulta of January 7, 1768 . 
the discretas. The reglamento established ninety as a desirable religious population for the foreseeable future and placed a moratorium on the admission of new novices, mandating that a double dowry be required of any supernumerary novices (e.g., novices exceeding the approved number that the Crown might compel the community to admit). ${ }^{93}$

The Crown approved Pinedo's reglamento on February 1, 1768 but retained the services of the bishop to ensure the "punctual observance" of the order's Rules and Constitutions, particularly with regard to the disputed enclosure measures, the administration of the convent's rents, and the appointment of its confessors. ${ }^{94}$ Such was in keeping with a general policy of Madrid to rely on bishops and archbishops to enforce monastic discipline in their dioceses. For example, in August of 1769, the Crown ordered bishops and archbishops throughout the empire to celebrate provincial councils. These provincial councils were intended to combat, among other things, relaxed monastic discipline, the failure of religious orders to

\author{
93 Ibid. \\ 94 AGI, SD 1136, Consulta, January 7, 1768.
}


observe their Rules, and the disobedience they often showed toward superiors. Less than a year later, in July of 1770, the crown ordered bishops and archbishops to report on religious conditions in their dioceses, instructing them to include information on whether or not convents observed their Rules and Constitutions and the vow of enclosure, on the administration of conventual rents, and on the appointment of confessors at convents. 95 The evolution of reform at Santa Clara paralleled contemporary reform in Mexican convents. Beginning in 1765, Bishop Fabián y Euero of Puebla, acting on a papal brief of Clement XI, laid the groundwork for restoring communal Iife to calzada convents under his jurisdiction. ${ }^{96}$ He began slowly in July of that year, ordering measures designed to end dependency on private resources. He ordered that worship services be simplified, forbade the use of extravagant ornamentation in convents, and prohibited the custom of giving jewels and other precious gifts to an abbess or another high-

95 Lavrin, "Ecclesiastical Reform of Nunneries," 188. común," 585 .

96 Ibid., 185; Sarabia, "Controversias sobre la "vida 
ranking officer to commemorate her election. A year later he banned protégés from sleeping in the same rooms as nuns and ordered that officials rotate office-holding every year and a half, rather than on a triennial basis. ${ }^{97}$

Having laid the groundwork, Fabián y Fuero stepped up his program of reform in August of 1768, ordering the reestablishment of communal life in all calzada convents of Puebla. He mandated that all expenses of the convent be administered on a communal basis, prohibited convents from administering to their members with money, banned personal servants from cloisters, ordered that nuns sleep in dormitories rather than in private cells, required that personal items be removed from the cells and applied toward communal use, mandated that all money received from private sources be incorporated into communal treasuries, and restricted familial visits to one every three months. The bishop assured disgruntled nuns that the reestablishment of communal life would give them more time to devote to spiritual concerns because it would relieve them of the burdens of private life (i.e., having to sell devotional items from the tornos and seek support from

97 Lavrin, "Ecclesiastical Reform," 185. 
their families to supplement meager incomes communal resources provided). ${ }^{98}$ A year later, Bishop Eabián $Y$ Fuero solicited royal approval of his reform measures. When that approval came in February of 1770, other prelates in the colony began imitating the bishop's reforms. ${ }^{99}$

Meanwhile in Cuba, the Franciscans were attempting to reestablish communal Iife at Santa Clara in accordance with Plácido de Pinedo's reglamento. With Pinedo gone from office, the task of reintroducing the regimen fell to his successor, Commissary General Manuel de la Vega. Unfortunately, Vega did not wait until the religious population of the convent was reduced to ninety to initiate other reforms.

98 Ibid. AGI, Ultramar 396, Manuel Estéves to the Crown, August 4, 1781 .

99 Lavrin, "Ecclesiastical Reform," 188. 
CHAPTER IV

A RESPITE EROM COMMUNAL LIFE, 1770-1782

The stringency of Plácido de Pinedo's reglamento and the timing of its enforcement ensured that the measure would not be effective in reestablishing communal life at Santa clara. Less than a year and a half after Manuel de la Vega enforced Pinedo's reglamento and reestablished communal life at the convent, he had to allow the community to return to private life, ushering in a respite from communal life that lasted more than a decade. In the interim between the suspension of communal life in 1770 and its re-introduction in 1783, the crown tried to keep abreast of the situation at Santa Clara, which proved difficult because reports coming from Havana often conflicted with one another. When the Council again turned its attention to the re-establishment of communal life at the convent in the early 1780s, it opted to apply the lenient cédula of May 22, 1774, rather than Pinedo's more stringent reglamento.

In 1769, acting on Vega's orders, Franciscan Provincial Andrés Menéndez reestablished communal life at Santa Clara in accordance with Pinedo's reglamento. Menéndez imposed an annual budget of 15,000 pesos upon the 
community. Administering the accounts of the community was a secular mayordomo, Juan Manuel de Aguirre. According to the most oft-repeated account, nuns with families in Havana had all of their meals brought in from the outside, while the others went hungry; eleven nuns died. After sixteen months, the commissary general mercifully ended this chapter of communal life. ${ }^{100}$ The episode was dubbed "the asylum from peace" (asilo de la paz) and "the scandal of the century." (escandalo del siglo). ${ }^{101}$ While the veracity of the account is questionable, one thing is not: the stringency of Pinedo's reglamento proved ill suited for reestablishing communal Iife at the convent.

100 AGI, Ultramar 396, Manuel Estéves to the Crown, August 4, 1781 .

101 Ibid. The officers of the convent referred to the episode in a March 20, 1783 letter to Manuel Estéves as the "escandalo del siglo," (AGI, Ultramar 396, Ana Antonia de la Natividad (abbess), María Isabel de San Miguel (madre de consejo), Agustina de Santa Coleta (madre de consejo), Bárbara de la Coronación (difinidora), Manuela de San Francisco (difinidora), María de Santa Clara (difinidora) to Manuel Estéves, March 28, 1783): Manuel Estéves, in a March 31, 1783 letter to Luis de Unzaga, referred to the same episode as "asilo de la paz" (AGI, Cuba 1343, Manuel Estéves to Luis de Unzaga, March 31. 1783). 
In Mexico too, the enforcement of communal life set off protests. For example, in 1773 the nuns of the Convent of La Santisima Trinidad of Puebla appealed to both the Viceroy of New Spain, Antonio de Bucareli, and to the Audiencia of Mexico, charging that Bishop Fabián $y$ Fuero had used "extraordinary and violent means" to introduce communal life at their convent. In 1774 the nuns of Santa Clara of Puebla, of the Franciscan Province of Santo Evangelio, appealed to Madrid concerning a fouryear old measure which reestablished communal life at their convent, petitioning the crown to return them to the private regimen. Like their sisters in Havana, the nuns of Santa Clara of Puebla claimed that their superiors had altered the custom under which they had taken their vows, one that had been maintained by previous prelates. The nuns also charged that their superiors had attempted to force them to embrace communal life by restricting visiting hours, expelling protégés, and walling up windows and open views through grilles. In response, the provincial of Santo Evangelio Province, Francisco García de Figueroa, assured the Crown that the measures were intended to make the nuns observe the vow of enclosure, not to compel them to embrace communal life. 
It was the resistance of Santa Inés of Puebla, however, that most captured the crown's attention. Divided between those who supported communal life and those who rejected it, the struggle escalated into open rebellion in February of 1772. A host of unconfirmed reports reaching Madrid in its aftermath alarmed officials in Madrid. As a result, the Crown issued cédulas in 1772 and 1773 , suspending the re-establishment of communal life in all Mexican convents with appeals pending. A subsequent investigation by the Archbishop of Mexico, Alonso Núñez de Haro, provisionally returned all convent's under Fabián and Fuero's jurisdiction to private life, pending a decision of the crown. ${ }^{102}$

That decision came in 1774. A cédula promulgated on May 22 of that year ordered the observance of communal life in all calzada convents. The Crown's intention was that the calzadas emulate the better disciplined recollect nuns who observed the communal regimen. However, tempered by innumerable complaints, the decree stipulated that professed nuns, who had taken their vows under the custom of private life, be left in complete liberty to either

102 Lavrin, "Ecclesiastical Reform," 188-193, 195. 
embrace or reject communal life. ${ }^{103}$ On the leniency of the decree, Lavrin comments: "This indulgent attitude of the Crown contrasts strongly with that of the prelates, whose imperious demands had produced chaos in the cloisters."104

The cédula gave the nuns fifteen days to deliberate on the matter, during which time they were expected to consult with their confessors and spiritual advisors. After two weeks, the superiors of the convents were to pass to collect the verdicts. Whereas professed nuns had the option of embracing communal life or continuing in their private regimen, novices enjoyed no such luxury: they were required to pledge themselves to a lifetime of communal living before a notary public. ${ }^{105}$

Those with aspirations of becoming officers also had to disavow private life, because the cédula mandated that officers be chosen from among those nuns who embraced communal life. If fewer than three nuns in a community spontaneously embraced communal life, the officers had to

\footnotetext{
103 AGI, Ultramar 396, Cédula (Copy), May 22, 1774.

104 Lavrin, "Ecclesiastical Reform," 193-194.

105 AGI, Ultramar 396, Cédula (Copy), May 22, 1774.
} 
be chosen from among the best qualified, with the understanding that the future officeholders come from the pool of novices who had sworn themselves to live communally (the laws of an order determined the time required for a nun to become eligible for office). The Crown's message was clear: in filling positions of leadership, those who embraced communal life were preferred over those who did not, regardless of ability or experience. In all other aspects of conventual life, however, the cédula mandated that the nuns be treated equally. This was particularly true with regard to finances, which were to be disbursed equally among all of the nuns in a community. ${ }^{106}$

In promulgating the cédula, the crown also attempted to minimize contact between nuns and secular women by ordering that secular females be admitted only with the approval of the convent's immediate superior, who was expected to act with great restraint in this regard. An exception was made for protégés: convents that traditionally had admitted young girls for the purpose of grooming them for the novitiate could continue to do so.

106 Ibid. 
No exception was made for servants, the large underclass that swelled the populations of convents everywhere: the cédula required that nuns entering into communal life dispense with their personal servants, and that those continuing in the private regimen limit themselves to one. Addressed to the Viceroy of New Spain, copies of the cédula were sent to Archbishop of Mexico, the Bishop of Puebla, "and the rest of the prelates of that kingdom."107 In Cuba, Governor Felipe de Fonsdeviela (the Marqués de la Torre) confirmed in 1772 that the reglamento had wrought little outward change at Santa clara. There were still more than one-hundred nuns, an equal number of servants, and numerous protégés and retirees living at the convent. Communal resources still did not suffice despite annual rents of 40,000 pesos, meaning that the nuns continued to turn to their families for support. Because Santa Clara's Franciscan superiors were the only ones who had access to the convent's account books, the governor lamented in his June 1772 report that he could neither diagnose what ailed the community nor offer a remedy. ${ }^{108}$

107 Ibid.

108 AGI, SD 1418, Marqués de la Torre to the Crown, June 17,1772 . 
The governor's revelations disturbed the fiscal of the Council. In a respuesta of october 5, 1773, the official labeled the severance of Franciscan involvement from the management, administration, and collection of the convent's rents "the most substantial point of Pinedo's reglamento" and, accordingly, recommended that the commissary general enforce the reglamento, removing any Franciscan from involvement in Santa Clara's financial affairs. He also suggested that the bishop and the governor act as watchdogs, verifying that the commissary carried out the orders. ${ }^{109}$ More than four years passed, however, before the council acted on the fiscal's recommendations. In the interim, another controversy captured the Council's attention.

Rather than end all supernumerary admissions, as required by Pinedo's reglamento, Commissary General Vega had left the door slightly ajar. In a compromise move, Vega implemented measures designed to maintain the vibrancy of the Observant Franciscan community and, at the same time, discourage admissions. He ordered that one

109 AGI, SD 1418, Respuesta of the fiscal, October 5, 1773, written in the margin of the June 17, 1772 letter of the Marqués de la Torre. 
novice be admitted for every five nuns that died and, in accordance with Pinedo's reglamento, required a double dowry be paid by all supernumerary entrants. When the latter proved ineffective, he rescinded it, but not before compromising the Crown's initiative to reduce the convent's religious population. Four new novices entered Santa clara under the pretext of a double dowry. ${ }^{110}$ In 1777, seven years after Vega suspended communal life at Santa Clara pending a reduction in the number of nuns to ninety, there were still ninety-nine nuns living at the convent. ${ }^{111}$

Disturbed by the commissary general's failure to close the door to new novices, the council took control of admissions at the convent on October 1, 1777, pledging to retain control until the religious population of Santa Clara was reduced to ninety. ${ }^{112}$ The Council also

110 AGI, SD 1411, Santiago José de Hechavarría to the Council of the Indies, July 16, 1775, summarized in the August 7, 1777 respuesta of the fiscal, which is attached to the March 3, 1777 expediente of María Loreto Ruíz.

111 AGI, SD 1411, Manuel de la Vega to the Council of the Indies, April 28, 1777, attached to the March 3, 1777 expediente of María Loreto Ruiz.

112 Ruling of the Council of the Indies summarized in AGI, SD 1411, Manuel de la Vega to the Council of the 
instructed Vega to see that families that had paid double dowries were refunded the cost of the second dowry. ${ }^{113}$

The commissary general was surprised by the Council's objection to the use of double dowries as a deterrent, since the Crown had approved their use when it sanctioned Pinedo's reglamento in 1768. Nonetheless, Vega deferred to the Council's judgment, agreeing on October 9, 1777 to issue orders so that the families or benefactors affected by the measure were reimbursed. At the same time he agreed to prohibit the provincial from conceding a license for any girl to become a novice at Santa Clara until the number of nuns had been reduced to ninety. ${ }^{114}$

In early 1778, just when all seemed to be settled, the Council revisited the report that the Marqués de la Torre had penned almost six years earlier. Citing the troubling revelations contained therein, the tribunal called upon Vega, once again, to enforce Pinedo's

Indies, October 9, 1777, attached to the expediente of María Loreto Ruíz of March 3, 1777.

113 Ibid.

114 Ibid. 
reglamento in its entirety. ${ }^{115}$ To ensure compliance, the Council solicited the help of Governor Diego José Navarro, the successor to the Marqués de la Torre, and Bishop Santiago José de Hechavarría. A cédula of May 6, 1778 instructed the two to verify that the commissary general carried out the Council's instructions and to report on anything else either of the two deemed relevant. ${ }^{116}$ The cédula also ordered the bishop to review the authority vested in him by the episcopate to determine if the powers it entailed were sufficient to oversee the enforcement of the reglamento at Santa Clara or if those powers needed to be bolstered with royal authority. ${ }^{117}$

The marquis' concerns that a Eranciscan administered the financial affairs of Santa Clara appears to have been

115 Ibid.

116 AGI, SD 1418, Diego José Navarro to the Council of the Indies, September 6, 1778, and Santiago José de Hechavarria to the Council of the Indies, November 16 , 1778, both attached to the February 20, 1778 expediente of the Marqués de la Torre.

117 Ibid. AGI, SD 1418, Manuel de Ia Vega to the Council of the Indies, May 20, 1778, and Diego José Navarro to the Council of the Indies, September 6, 1778, attached to the February 20, 1778 expediente of the Marqués de la Torre. 
the main impetus to re-open the issue of reform at the convent. But once reopened, all of his concerns became those of the Council. None of the correspondence identifies the marquis' letter as the source of the Council's new concerns. All merely refers to "confidential and reliable news" reaching Madrid. Nor does any documentation indicate why the Council waited almost six years to address the concerns raised in the marquis' 1772 letter. By then, many of them were no longer relevant. This fact was not lost on the commissary general. In a letter of May 20, 1778 Vega contended that all reports he had received from Havana indicated that the community was in relatively good discipline. The commissary general was perplexed by the timing of the Council's orders and disturbed by what he perceived to be an insensitive informant. In Vega's estimation the criticism was not constructive but damaging to the community's good name. ${ }^{118}$

The commissary general imagined that either Bishop Hechavarria or the secular mayordomo of the convent, Tomás

I18 AGI, SD 1418, Manuel de la Vega to the Council of the Indies, May 20, 1778, attached to the February 20, 1778 expediente of the Marqués de la Torre. 
Cervantes, was behind the report. The long-running jurisdictional dispute between the bishop and the Franciscans explains his willingness to blame the bishop. Vega's suspicion of the mayordomo stemmed from an incident which occurred three years earlier. In 1775 cervantes had solicited a raise in pay from 600 to 800 pesos annually. The nuns first acquiesced in the mayordomo's request, then later reversed their decision. The commissary general suspected that the incident had left the mayordomo bitter. 119

Vega expressed his doubts concerning the veracity of the report in the Council's possession, contending that it conflicted with reports he was receiving from Havana. As an example of the latter he cited a report "from a person of great authority (and not a religious)" who labeled Santa Elena Province "very well governed" (tan felizmente gobernada). Although the commissary general could not guarantee the Council that the nuns were in perfect observance of the reglamento, he assured the tribunal that he had no reason to think otherwise on the basis of reports he had received from Havana. Vega noted that on

119 Ibid. 
the basis of such reports, the community of Santa clara was stricter in its observance of the Order's Rules and Constitutions than many under his jurisdiction. ${ }^{120}$

The commissary general suggested to the Council that the female temperament, rather than any real hardship, was to blame for the nuns' tendency to turn to their families for support. As proof that the nuns received adequate communal support, he cited the account books of the convent. According to the books each nun was supposed to receive weekly allotments of a pound of meat, eighteen ounces of bacon, a quarter pound of bread and a quarter pound of casaba. The total cost of these food items was budgeted at 18,000 pesos a year. Each nun also was supposed to receive rations of chocolate, soap, shoes, and other necessities. Seven thousand four hundred pesos were budgeted to cover the cost of these items. Finally, there were allowances for clothes and medical care, which included the services of a surgeon and a bleeder. The cost of these goods and services totaled an additional 2,400 pesos a year. ${ }^{121}$

120 Ibid.
121 Ibid. 
The commissary general adamantly denied the marquis' claim that a friar administered the convent's rents or any suggestion that the rents were poorly administered. He reminded the Council that a secular mayordomo, Miguel Aguirre, had administered Santa Clara's rents even before Pinedo mandated such in his reglamento and that since March 23, 1773 Tomás Cervantes had served as mayordomo without any intervention from the friars. Upon assuming the post, Cervantes also assumed an obligation to pay his predecessor, Aguirre, a third of his annual salary of 600 pesos, which explains why he petitioned for a salary increase. 122

Citing the mayordomo's 1775 petition for a salary increase, Vega suggested that Cervantes' claims of having liquidated all bad debts and having established improved monthly accounting procedures by creating separate books for expenses, debits, and rents proved that he was the mayordomo. As evidence that the rents were well managed, the commissary general again referred to Cervantes' 1775 letter, in which the mayordomo boasted that the accounts

122 Ibid. 
of the convent had never been in better shape and reported that the community had on hand a balance of 5,492 pesos. ${ }^{123}$ The Council received reports from the governor and the bishop in the winter of 1778. Although not in perfect unison, the reports were fairly consistent in their portrayals of the situation at Santa Clara. Neither portrayed a community in perfect discipline, but both depicted one that had made considerable strides in the decade since the Crown sanctioned Pinedo's reglamento. ${ }^{124}$

Navarro and Hechavarria acknowledged that the community had reformed several practices which previously had drawn criticism from either Bishop Morell de Santa Cruz or the Franciscan visitador, Manuel Crespo. Most importantly the office of superintendente had been abolished and a secular mayordomo administered the convent's rents.125 Also the community no longer staged

123 Ibid.

124 AGI, SD 1418, Diego Jose Navarro to the Council of the Indies, September 6, 1778, and Santiago José de Hechavarria to the Council of the Indies, November 16 , 1778, attached to the February 20, 1778 expediente of the Marqués de la Torre.

125 Ibid. 
elaborate celebrations to commemorate an election or visit of a provincial or to mark a special feast day. According to Navarro, the nuns celebrated only one feast day a year with their Franciscan brethren: that of Saint Clare which coincided with the feast of Saint Francis. Navarro reported that on the feast of st. Clare, the community slaughtered a cow, a pig, twelve chickens, and prepared a dessert.126 Also, the community no longer invested its censos without proper oversight, and it had reduced the superfluous expenses associated with holding office at the convent and had curbed the amount of propinas required of candidates to the novitiate. The number of protégés and retirees at the convent also had been reduced.

The community continued to fall short of perfection in a few important areas. The religious and servantpopulations of the convent were little diminished from the previous decade. The governor reported that ninety-nine nuns were living at Santa Clara; whereas the bishop reported that 100 nuns were living at the convent and that these nuns continued to maintain their personal servants.

126 AGI, SD 1418, Diego José Navarro to the Council of the Indies, September 6, 1778, attached to the February 20, 1778 expediente of the Marqués de la Torre. 
More importantly, however, the community still failed to observe communal life. On the question of whether real hardship lay behind the nuns' decision to turn to their families for support, Navarro argued that it did not. Although aware that the nuns spent, on average, twice their annual allotment of 137 pesos, the governor was convinced that elite families supplemented their daughters' incomes out of choice. Hechavarría, by contrast, argued that the nuns were forced to turn to their families for support because communal funds failed to cover the cost of the basic necessities of Iife. Although the governor and the bishop disagreed on the nuns' motive for turning to their families, they agreed that the sisters relied heavily on private support. ${ }^{127}$ Concerning the question of whether the ecclesiastical authority of the bishop was sufficient to adequately monitor the enforcement of the reglamento at Santa Clara, Hechavarria answered that it was not. In fact the bishop conceded that he had yet to act in accordance with the

127 AGI, SD 1418, Diego José Navarro to the Council of the Indies, September 6, 1778, and Santiago José de Hechavarria to the Council of the Indies, November 16 , 1778, attached to the February 20, 1778 expediente of the Marqués de la Torre. 
cédula of April 5, 1768, which had attributed broad powers to his office, powers Hechavarría was convinced he did not possess. For example, the cédula called upon the bishop, who at the time was Morell de Santa Cruz, to make a visita to the interior of the convent, concur in the election of the abbess, approve the admission of novices, and examine the account books of the convent. Hechavarria, the first native-born bishop of Cuba, was familiar with, and wary of, the forces that controlled Santa Clara. ${ }^{128}$ In his report to the Council, the bishop expressed his reluctance to move against an institution "comprised of so many nuns, many from the first families of [the] city, who made the convent's business their own" or to infringe upon the authority of the Franciscans, who had "an interest in conserving their prerogative to the exclusion of other authority."129

128 AGI, SD 1418, Santiago José de Hechavarría to the Council of the Indies, November 16, 1778, attached to the February 20, 1778 expediente of the Marqués de la Torre; Hechavarría was Cuba's first native-born bishop. Designated bishop in 1769, he assumed power in 1770 (Juan Martín Leiseca, Apuntes para la historia eclesiástica de Cuba (Havana: Carasa y Cía., 1938), 125).

129 AGI, SD 1418, Santiago José de Hechavarría to the Council of the Indies, November 16, 1778, attached to the February 20, 1778 expediente of the Marqués de la Torre. 
Hechavarria recently had addressed the question of his authority to review the account books of Santa clara in a synod which was concluded on August 1, 1778. Still pending the king's approval, the synod issued a "constitution" that called for the bishop, accompanied by a regular superior of Santa Clara, to examine the convent's books. ${ }^{130}$ When Hechavarria attached this document to his November 16, 1778 report for royal approval, he requested that the governor participate in the examination as well.131 The bishop proposed that this junta--comprised of a regular superior of the convent (e.g. the provincial), the governor, and himself--analyze the community's annual rents and its capital, reconcile the ledgers to determine if there were any excess expenses, calculate the true costs associated with professing at Santa Clara, determine if the community was fairly taxed, decide if its investments were appropriate or too risky, and determine definitively if it was

130 Ibid.

131 AGI, SD 1418, Testimonio of Pedro de Hechavarría, November 3, 1778, attached to the November 16, 1778 letter of Santiago José de Hechavarría to the Council of the Indies. 
realistic to expect the nuns to observe communal life once the religious population of the convent was reduced to ninety.132

Whereas the bishop's authority to examine the account books of the convent was treated in canon law, the governor's authority to participate was less apparent. ${ }^{133}$ After all, patronal guidance did not extend its tentacles into the interior government of a convent. Nonetheless, the Council of the Indies recognized no legal impediment to the governor's participation. In a respuesta of July 25, 1779 the fiscal of the Council labeled the examination of Santa Clara's account books a "purely temporal" concern that neither infringed upon spiritual jurisdiction nor the interior government of the convent. ${ }^{134}$

132 AGI, SD 1418, Santiago José de Hechavarría to the Council of the Indies, November 16, 1778, attached to the February 20, 1778 expediente of the Marqués de la Torre.

133 The "constitution" of the synod concluded on August 1, 1778 indicated that such authority was derived from bulls of Gregory X (inscrutabili) and Benedict XIV (AGI, SD 1418, Testimonio of Pedro de Hechavarría, November 3, 1778, attached to the November 16, 1778 letter of Santiago José de Hechavarria to the Council of the Indies).

134 AGI, SD 1418, Respuesta of the fiscal, July 25, 1779, attached to the February 20, 1778 expediente of the Marqués de la Torre. 
Although satisfied that the community was in relatively good discipline and that its rents were administered in accordance with Pinedo's reglamento, the Crown, not surprisingly, was disturbed by Santa Clara's large population and its failure to observe communal life. In a royal cédula of November 19, 1779 the Crown ordered the commissary general to reestablish communal ife once the religious population numbered no more than ninety and gave the bishop and the governor the authority to examine Santa Clara's account books. ${ }^{135}$

The Crown's decision to have the bishop and governor review the account books of Santa Clara sparked relatively little controversy. Occupied with other concerns, Hechavarría was slow to order an audit of the convent's books. When he finally did so in 1781, it came at the urging of the nuns, who had grown impatient waiting for the diocesan official to act. Only one obstacle stood in the way of the review: the nuns steadfastly refused to allow the account books to leave the convent. ${ }^{136}$ The

135 Ibid. AGI, SD 1418, Cédula (Draft), November 19, 1779, attached to the February 20, 1778 expediente of the Marqués de la Torre.

136 AGI, Ultramar 396, Ana Antonia de la Natividad (abbess), Rosa María de San Miguel (madre de consejo), 
auditors appointed by the bishop and governor, the provisor auxiliar (vicar general) of the diocese and the Marqués Cardenas de Monte-Hermoso, ran into opposition when they sought to have the account books removed from the convent and deposited in the secretariat of the bishop. When they asked Tomás Cervantes to deliver the account books to the secretariat, the mayordomo deferred, saying he lacked the authority to do so. The auditors then turned to the provincial, who refused their request as well, citing the reasons why the nuns refused to allow the books to leave the convent. ${ }^{137}$ The primary reason was that the Order's Constitutions stipulated that the account books remain in the contaduria (counting room). There, the books were kept in the arca de tres llaves (a chest to which the abbess, the depositaria and the vicar each had a key). A second, more practical, reason was that the contadora (nun comptroller) and depositaria, the two nuns who handled the daily purchases, were available for

Augustina de Santa Coleta (madre de consejo), Inés Gertrudís de San Josef (vicaria de la casa), Dominga de San Nicolás (discreta), Bárbara de la Coronación (discreta) to the Crown, July 19, 1781.

137 Ibid. 
consultation in the contaduria, as were the vouchers from the daily purchases. ${ }^{138}$

Unable to resolve this issue, both sides appealed to Madrid, with the bishop citing the noise level in the contaduria and other inadequacies as reasons for the proposed change of venue. In a letter to José de Gálvez, dated July 20, 1781, the nuns contended that the contaduria was a proper setting for the review. Although the room bordered the street, the sisters argued that noise level was not so high as to disturb the audit, pointing out that street noise had never bothered the mayordomo, who assisted the nuns in the contaduria daily from eight a.m. until noon. ${ }^{139}$ In a letter of the same day to José de Gálvez, the nuns stressed that the environment of contaduria was in keeping with the dignity of the two

138 Ibid.

139 AGI, Ultramar 396, Ana Antonia de la Natividad (abbess), Rosa María de San Miguel (madre de consejo), Augustina de Santa Coleta (madre de consejo), Inés Gertrudis de San Josef (vicaria de la casa), Dominga de San Nicolás (discreta), Bárbara de la Coronación (discreta) to José de Gálvez, July 20, 1781; For discussion of the duties of the mayordomo see AGI, SD 1418, Manuel de la Vega to the Council of the Indies, May 20,1778 . 
auditors. They reasoned that if it was good enough for visiting dignitaries, such as bishops, governors, archbishops, and viceroys, it was fitting enough for the two mid-level appointees. ${ }^{140}$ The commissary general was supportive of the nuns' position, noting in a letter of January 12, 1782 that the bishop himself had visited the contaduria on numerous occasions, "without losing his dignity, authority, and image."141 The dispute apparently was settled in favor of the auditors, because two years later, on May 24, 1783, the abbess of Santa Clara, Ana Antonia de la Natividad, stated that the provincial removed the account books from the convent for "fifteen or twenty days" each year. ${ }^{142}$

The decision to audit Santa clara's account books sparked little controversy in comparison to the deluge

140 AGI, Ultramar 396, Ana Antonia de la Natividad (abbess), Rosa María de San Miguel (madre de consejo), Augustina de Santa Coleta (madre de consejo), Inés Gertrudis de San Josef (vicaria de la casa), Dominga de San Nicolás (discreta), Bárbara de la Coronación (discreta) to José de Gálvez, July 20, 1781.

141 AGI, Ultramar 396, Manuel de la Vega to the Council of the Indies, January 12, 1782.

142 Ultramar 396, Ana Antonia de la Natividad to the King, May 24, 1783. 
that the re-establishment of communal life caused. The unenviable task of reestablishing communal life at the convent fell to Manuel Estéves, a Eranciscan vicar provincial in Havana. The task of instituting communal Iife at Santa Clara should have fallen to Estéves' predecessor, who received the cédula of November 19, 1779 from the bishop on April 10, 1780, but he died before implementing the measure. Vicar Provincial Estéves previously had served the observant Franciscan community in a number of capacities, including vicar. As a result, he was very familiar with the nuns. Although impressed by their pedigree and education, he held a very low opinion of their monastic discipline, labeling them "lukewarm" and "frigid" in the observance of their profession.143

When Santa Clara's religious population had been reduced to ninety-one in the summer of 1781, Estéves began to explore the possibility of introducing communal life at the convent. The provincial first set out to discover the roots of private life (what he termed the convent's "decadence"). He delved into Santa Clara's archives,

143 AGI, Ultramar 396, Testimonio of Josef Antonio Barrios, May 16, 1783, and Manuel Estéves to the Crown, August 4, 1781. 
poring over visitas conducted at the convent, but found no answers. He interviewed the oldest members of the community, the octogenarians, but discovered not a single one who recalled a time when communal life was practiced. Unable to pinpoint the roots of the convent's "decadence," the vicar provincial concluded that private life had been the custom at Santa Clara for "at least a century." Estéves concluded that within a couple of generations of the convent's founding initial fervor was lost, rents became poorly administered, increasing amounts of food and provisions were introduced from the outside, and the nuns settled into a lifestyle that was more private than communal, dressing and eating of their own accord.144

In a report of August 4, 1781 Estéves informed the Crown that the nuns of Santa Clara lived quite well in private life and had no desire to embrace communal life. Regardless of whether or not the sisters embraced communal life, the vicar provincial argued that with 40,000 pesos in annual rents the nuns should have been able to live quite well. Estimating that expenses of the sacristy consumed 10,000 pesos annually, Estéves created a budget

144 Ibid. 
based on an annual income of 30,000 pesos. He budgeted 27,000 pesos for a mesada (a monthly allotment of twentyfive pesos per nun) and dedicated the 3,000-peso balance and another 7,500 pesos in projected annual dowry contributions toward the myriad of expenses the convent incurred each year. In projecting dowry contributions, Estéves estimated that five novices would enter Santa Clara over a two-year period, contributing dowries of 3,000 pesos each, which amounted to 15,000 pesos, or 7,500 pesos annually. The vicar provincial assured the Crown that on 30,000 pesos, 150 whites, owning seventy-five slaves could live in fifteen households "in the comfort of nobility" in Havana. That being so, he contended that 30,000 pesos were enough to maintain ninety nuns and their ninety personal servants under one roof at Santa Clara. ${ }^{145}$

Although Estéves was a proponent of communal life, he was reluctant to enforce the regimen at Santa clara, perhaps fearing the wrath of the nuns and their powerful families. Referring to the small number of Recollect Dominicans and Discalced Carmelites of the city, the vicar provincial questioned whether those nuns, living off the

145 Ibid. 
proceeds of their rents and the sale of scapulars and other devotional items at the torno, were necessarily any less corrupted than the observant Franciscans relying on private resources of their wealthy families. He claimed that the belief that they were less corrupted had Ied Commissary General Manuel de la Vega to order the provincial, Andrés Menéndez, to enforce the reglamento of 1768 "con pura fuerza." Not wanting to repeat the 1769-70 debacle, Estéves suggested that a compromise might be found in the cédula of May 22, 1774, which had been written for Mexico. He praised the royal decree as a measure which could preserve the peace of the cloister and, at the same time, ensure that with the passing of a generation all at Santa Clara would observe communal life. However, he did acknowledge that a clause in the cédula, the one which stipulated that officers come from among those nuns who embraced communal life, posed a dilemma if officeholders and aspiring officeholders preferred private life. On the nuns' behalf, Estéves appealed to the crown to do one of three things: revoke the order to observe communal life in its entirety; introduce communal life with the leniency of the cedula of 1774, but with the stipulation that the nuns be left in complete liberty with 
regard to elections; or implement a compromise, thus permitting the nuns to live in a relaxed form of communal life. ${ }^{146}$

In Madrid, the commissary general was little surprised by the nuns' opposition. Cognizant of the fact that the nuns had rebuffed every past attempt to reestablish communal life--the "persuasions, encouragement, and admonishments" of its superiors, decisions of the Council and the royal orders which proceeded from them, and papal law which mandated harsh punishment for offenders--Vega supported the vicar provincial's effort to find a happy medium. ${ }^{147}$ In a letter of January 12, 1782, he predicted that the royal cedula of May 22, 1774 would prove more effective in reestablishing communal life than harsher measures, even suggesting that

146 Ibid.

147 Vega noted that tridentine law (ad excusandas excusationes in peccatis) labeled private life a "mortal sin" and reproved any innovation or relaxation of communal life, regardless of whether a nun professed her vows under the private regimen. He added that bulls of Clement VIII (pro. reform. regular) and Innocent $X$ (consitit) denied the right to receive novices to any convent not in perfect observance of communal life (AGI, Ultramar 396, Manuel de la Vega to the Council of the Indies, January 12, 1782). 
as many as "thirty or forty" nuns at santa clara might embrace communal life under the terms of the cédula. For the time being, however, he saw no alternative but to opt for the third of Estéves' alternatives, leaving the nuns in private life or in an "imperfect and relaxed" form of communal life. ${ }^{148}$

The Council of the Indies was not familiar with the cédula of May 22, 1774 and had to request a copy from José de Gálvez.149 After reviewing the document, the fiscal of the Council judged it applicable to Santa Clara. Although the decree was directed specifically at the "calzada convents of [New Spain]," the official determined that the specification was nothing more than a "demonstrative phrase." He argued that the Crown's true intention had been for the cédula to apply to all convents where

148 AGI, Ultramar 396, Manuel de la Vega to the Council of the Indies, January 12, 1782.

149 AGI, Ultramar 396, Antonio Ventura de Taranco to José de Gálvez, February 23, 1782; Three weeks later, on March 12, 1782, Gálvez sent a copy of the cédula to Taranco (AGI, Ultramar 396, José de Gálvez to Antonio Ventura de Taranco, March 12, 1782). 
communal life was not practiced. ${ }^{150}$ The Council, and subsequently the Crown, agreed with the fiscal's dictum. The cédula of May 22, 1774 was inserted in another of August 10, 1782 and copies were sent to the Bishop of Cuba, the island's governor, and the Franciscan vicar provincial, Estéves. The 1782 cédula stipulated that the nuns were to suffer neither "extortion nor violence" in the introduction of communal life. It cautioned Estéves to reestablish communal life with leniency and instructed the bishop and the governor to verify that the nuns were neither "molested nor oppressed."151

Unfortunately, in the interim between his August 4, 1781 appeal to the crown for compromise and the arrival of the cédula, Estéves made an ill-fated attempt to reform Santa clara on his own. In a month-long visita, conducted between April 7 and May 5 of 1782, the vicar provincial antagonized the nuns with a series of reform measures which often had little, if anything, to do with the re28,1782 .

150 AGI, Ultramar 396, Respuesta of the fiscal, April

151 AGI, U1tramar 396, Manuel Estéves to the Crown, May 8, 1783. 
establishment of communal life. For example, he removed all but two alters from the convent's church and reduced the time allowed for silent prayer from two hours to one. Faced with unyielding opposition to his reform efforts, the vicar provincial rescinded the controversial measures and waited for an answer to his August 4, 1781 letter. ${ }^{152}$ Thus by August 1782 the goals established in Plácido de Pinedo's 1768 reglamento appeared to be in reach. Although the community of Santa Clara remained opposed to the re-establishment of communal life, it had witnessed a ten percent reduction in its religious population. Between 1778 and 1781, the number of nuns living at Santa Clara dropped from approximately 100 to ninety-one. In the decade prior to 1778 there had been no measurable reduction in Santa Clara's religious population due to the liberal admissions policy of Commissary General Vega. While Vega's liberal admissions policy was the catalyst for the slow population decline, Havana's elite was the culprit that stalled the decline. The manner in which the

152 AGI, Ultramar 396, Testimonio Josef Antonio Barrios, May 16, 1783. 
Havana elite frustrated reform efforts during the decade of the 1770s deserves further examination. 
CHAPTER V

SUPERNUMERARY ADMISSIONS AND DOUBLE DOWRIES

Prior to the mid-1770s, the Council had assumed that Commissary General Vega ordered a moratorium on the admission of all new novices at Santa Clara to ensure that the religious population of the convent would be reduced to ninety, as mandated in Plácido de Pinedo's reglamento. As noted in the previous chapter, however, the commissary general had chosen to implement a less stringent policy, admitting one novice for every five nuns that died and requiring all aspirants to contribute two dowries. Upon learning of the prelate's innovations, the council of the Indies quickly moved to end the practices. Although the controversies surrounding supernumerary admissions and double dowries were relatively short-lived, they demonstrate the lengths to which the elite was willing to go to have its daughters admitted to santa clara.

Supernumerary admissions first became an issue in the spring of 1777 when the crown considered a petition for a young habanera, María Loreto Ruiz, to be admitted to the novitiate at Santa Clara. Attached to the February 23, 1777 petition was a patente of Commissary General Manuel de Ia Vega, dated July 22, 1776, approving her request. 
In the past a patente of the commissary general alone would have sufficed to admit Loreto Ruiz at the convent. However, much had changed by 1777 . The community refused to admit the aspirant on the grounds that the patente did not have the royal stamp of approval. ${ }^{153}$

Before ruling on the petition, the Council solicited additional information from the commissary general concerning María Loreto Ruiz's social status, the circumstances under which she sought admission, and the religious population of the convent. ${ }^{154}$ Vega responded to the Council's inquiry by reporting in a letter of April 28, 1777 that Loreto Ruiz "was from one of the principal families of Havana, although not one of the most powerful." The commissary general explained that he had

153 AGI, SD 1411, Domingo Sánchez Barrero to the Crown (on behalf of María Loreto Ruiz), February 23, 1777, and a patente of Manuel de la Vega, July 22, 1776, both attached to an August 7, 1777 expediente of Maria Loreto Ruiz.

154 AGI, SD 1411, Respuesta of the fiscal, March 18, 1777, written in the margin of Domingo Sánchez Barrero's February 23, 1777 letter to the Crown (on behalf of Maria Loreto Ruiz), which is attached to the August 7, 1777 expediente of Maria Loreto Ruiz, and an acuerdo of the Council of the Indies, April 17, 1777, also written in the margin of Domingo Sánchez Barrero's Eebruary 23, 1777 letter to the crown. 
admitted her in the belief that her desire to become a nun was authentic. Confirming that the religious population of Santa Clara was little reduced from the previous decade (he admitted that there were ninety-nine nuns living at the convent), Vega incriminated himself by revealing that he had allowed two other (unnamed) novices to enter. He had admitted the novices as part of his policy designed to both ensure the continued vibrancy of the community and avoid frustrating the desires of the many vecinas of Havana who aspired to the religious life. ${ }^{155}$

Another important factor in the commissary general's decision to grant a license to Maria Loreto Ruiz was a letter he received in late 1775 or early 1776 from Juan Barcelo, the Eranciscan provincial in Havana. Dated October 15, 1775, the letter related a series of events that recently had transpired in Havana. Bishop Santiago José de Hechavarría had asked Barcelo to arrange for María Loreto Ruiz and another girl, Francisca del Castillo, the daughter of the Third Marqués de San Felipe y Santiago, to enter Santa Clara. The arrangement that the provincial

155 AGI, SD 1411, Manuel de la Vega to the Council of the Indies, April 28, 1776, attached to the August 7, 1777 expediente of María Loreto Ruiz. 
negotiated with the nuns, however, was not to the bishop's satisfaction. The nuns agreed to admit Loreto Ruiz and Castillo to the convent, but only on the condition that they enter as servants, which they did. Although there is no documentation to indicate in what status the bishop requested that Maria Loreto Ruiz and Francisca del Castillo be admitted to Santa Clara, it appears that the diocesan prelate intended that the two be admitted as protégés, at the very least, with a right to accede to the novitiate at the first vacancy. ${ }^{156}$

With the offspring of two of Havana's most illustrious families housed in the servant quarters of the convent and with other elite families clamoring to have their daughters admitted to the novitiate there, the bishop asked Barcelo to write to Vega in hopes that the commissary general might convince the crown to lift its ban on the admission of new novices at the convent. ${ }^{157}$

156 María Loreto Ruíz and Francisca del Castillo were admitted to the servant quarters on the same day that another girl, described by Juan Barcelo only as the "niece of Padre Vargas," entered the novitiate.

157 AGI, SD 1411, Juan Barcelo to Manuel de la Vega, October 15, 1776, summarized in Manuel de la Vega's April 28, 1777 letter to the Council of the Indies, which is attached to the August 7, 1777 expediente of Maria Loreto Ruiz. 
Although there is no evidence to suggest that Commissary General Vega acted in accordance with the bishop's request, he did concede a Iicense for Maria Loreto Ruiz to enter the novitiate at the convent, as evidenced by the patente that was presented to the Council on her behalf. ${ }^{158}$ Vega's revelation that he had continued to admit novices at Santa Clara, despite the fact that the religious population of the convent exceeded ninety, troubled the Council. Compounding its concern was that the revelation lent credence to accusations made earlier by Bishop Hechavarría. ${ }^{159}$ In 1775 Hechavarría charged that the commissary general had allowed four novices--Maria de Jesús Arriola, María Catalina de San Gerónimo Guazo, Ana Lugarda de la Natividad Chacón, and Clara de Santa María de los Desamparados Guifano--to enter Santa Clara under the pretext of a double dowry of 4,300 pesos $(2,150 \times 2)$.

158 AGI, SD 1411, Patente of Manuel de la Vega, July 22, 1776, attached to Domingo Sánchez Barrero's February 23, 1777 letter to the Crown (on behalf of Maria Loreto Ruiz), both attached to the August 7, 1777 expediente of María Loreto Ruiz.

159 AGI, SD 1411, Respuesta of the fiscal, August 7, 1777, attached to the expediente of Maria Loreto Ruiz of the same date. 
According to Hechavarría, Sister María de Jesús Arriola entered with a patente of the commissary general, while the other three had done so with the provincial's approval, who acted on Vega's instructions. The bishop accused Vega of posing "serious harm to the royal treasury and to the "republica'" with the policy and insisted that future novices enter only with his permission. ${ }^{160}$

Having revisited Hechavarría's July 16, 1775 letter, the Council gave Commissary General Vega an opportunity to respond to the charges therein. In a letter of May 12, 1777 Vega reminded the Council that Santa Clara was exempt from diocesan jurisdiction and that, on this basis, the bishop had no authority to admit novices at the convent. The commissary general contrasted his own actions with those of the bishop, who he accused of petitioning the commissariat to admit Josefa Lizundia to the novitiate at Santa Clara. ${ }^{161}$ It is unclear whether Vega actually

160 AGI, SD 1411, Santiago José de Hechavarría to the Crown, July 16, 1775, summarized in the August 7, 1777 respuesta of the fiscal, which is attached to the expediente of María Loreto Ruiz of the same date.

161 AGI, SD 1411, Manuel de la Vega to the Council, May 12, 1777, summarized in the August 7, 1777 respuesta of the fiscal, which is attached to the expediente of María Loreto Ruiz of the same date. 
conceded a Iicense to Josefa Lizundia, the daughter of the first Marqués de Real Agrado (Domingo de Lizundia y Odría de Echevarria). The Marqués de Real Agrado was an alcalde ordinario and regidor perpetuo on the cabildo and the treasurer of the tobacco monopoly. He had been one of only two Spaniards to receive titles for service during the British occupation (the other being Lorenzo Montalvo, the marine intendant, who received the title of Conde de Macuriges) .162

Although Vega assured the Council that the requirement of a double dowry had been intended to discourage the elites of the city ("personas visibles $y$ caracterizadas") who frequently petitioned his office to admit their daughters to the novitiate at the convent, the policy had a fatal flaw. ${ }^{163}$ A double dowry of 4,300 pesos probably still seemed like a bargain to elite families of the city. After all, marriage dowries far exceeded that

162 Kuethe, Crown, Military, and Society, 52; Rafael Nieto y Cortadellas, Dignidades nobiliarias en Cuba (Madrid: Ediciones Cultura Hispanica, 1954), 411-412.

163 AGI, SD 1411, Manuel de la Vega to the Council, May 12, 1777, summarized in the August 7, 1777 respuesta of the fiscal, which is attached to the expediente of Maria Loreto Ruiz of the same date. 
amount. In Mexico City, for example, the marriage dowry for the daughter of a wealthy merchant could exceed 10,000 pesos and that for the daughter of a nobleman might range between 20,000 and 100,000 pesos, or even upwards of 300,000 pesos. ${ }^{164}$ By religious standards, 4,300 pesos was on the high end, but it was by no means extreme. The standard dowry at both Santa Clara and Santa Catalina of Cuzco was 3,312 pesos in the late eighteenth century, with some nuns contributing dowries of $5,000,10,000$, or even upwards of 15,000 pesos. ${ }^{165}$

After reviewing the charges and counter-charges of the bishop and the commissary general, the fiscal of the Council of the Indies concluded that both officials had failed to observe Pinedo's reglamento. Concerning Hechavarria's actions, the fiscal, in a respuesta of August 7, 1777, commented: "the bishop, portraying himself as the most zealous observer of royal decrees already has been the first to infringe upon them." The official was more sympathetic toward Vega, recognizing the rationale

164 Lavrin, "Colonial Woman in Mexico," 34.

165 Gibbs, "Cuzco," 66-67. 
behind the commissary general's actions. But still he criticized the Eranciscan prelate for failing to seek royal approval of his innovations. The fiscal did agree with Vega that the authority to admit novices at Santa Clara fell under Franciscan jurisdiction and accused the bishop of less than altruistic motives in seeking the authority to control admissions at the convent (i.e., the "preservation and enhancement of diocesan jurisdiction") . 166

The Council concluded that it was imperative to end supernumerary admissions at the convent and to effect the reimbursement of the second of the double dowries but, at the same time, deemed it would be unwise to alter the status of the four novices or the two servants who had entered Santa Clara. Until the religious population of the convent was reduced to ninety, certain extraordinary measures were to be enacted. For example, in the exploratory stage, which proceeded the profession of the novices, each novice was required to exhibit the license or patente with which she entered the convent. In the

166 AGI, SD 1411, Respuesta of the fiscal, August 7, 1777, attached to the expediente of Maria Loreto Ruiz of the same date. 
case that a Iicense was not approved by the Council, that novice would not be allowed to profess. Another safeguard required that the council be notified at the time a license or patente was granted, with the understanding that once the population fell below ninety, a license of a Franciscan prelate alone would suffice to admit a novice to Santa clara. Finally, the council concluded that individuals who had contributed double dowries should be reimbursed the cost of the second $(2,150$ pesos) and that the four affected novices (i.e., María de Jesús Arriola, María Catalina de San Gerónimo Guazo, Ana Lugarda de la Natividad Chacón, and Clara de Santa María de los Desamparados Guifanol should be allowed to profess their vows as planned but determined that Maria Loreto Ruiz and Francisca del Castillo should remain servants until the religious population of Santa Clara was reduced to ninety. ${ }^{167}$ on October 1, 1777 the Council informed the Commissary General of its decision. ${ }^{168}$ Two weeks later, on October 19, 1777, a cédula went out to Governor Diego José

167 Ibid.

168 AGI, SD 1466, Manuel de la Vega to the Council of the Indies, October 9, 1777, attached to the August 7, 1777 expediente of Maria Loreto Ruiz. 
Navarro, instructing him to advise those individuals who had paid the second dowries of the four novices to go to the convent to be reimbursed. ${ }^{169}$ Subsequently, the Council approved petitions allowing Francisca del Castillo and Antonia de Contreras to proceed to protégé status at the first vacancies in the secular huecos. ${ }^{170}$ Prior to approving the change of status for Castillo and Contreras, the Council had approved petitions for Francisca Guazo and two sisters, Rosalía and Brigida de Jesús Manso de Contreras, to enter in retiree status at the first vacancies in the secular huecos. ${ }^{171}$

169 AGI, SD 1422, Diego José Navarro to José de Gálvez, July 13, 1779, acknowledging completion of the order.

170 AGI, SD 1466, Expediente of Erancisca del Castillo (\#8), February 5, 1778, Acuerdo of the Council of the Indies, February 9, 1778, written at the end of the expediente of Francisca Castillo and Expediente of Antonia Contreras (\#9), Eebruary 5, 1778, and Acuerdo of the Council of the Indies, February 9, 1778, written at the end of the expediente of Contreras; Antonia de Contreras subsequentIy proceeded to the novitiate (AGI, SD 1142, Consulta, June 28, 1778).

171 AGI, SD 1466, Josef Prats $Y$ Miguel to the Crown, February 5, 1778; AGI, SD 1465, Acuerdo of the Council of the Indies, May 10, 1777, written at the end of the April 29, 1777 respuesta of the fiscal. 
The pedigrees of Francisca del Castillo and Antonia de Contreras demonstrate that Santa Clara was not only a bastion of the offspring of leading bureaucrats, wealthy merchants, large landowners, and high-ranking military officers, but of noblemen as well. According to Asunción Lavrin the daughters of titled families seldom entered Mexican convents, a fact she attributes to an awareness that "the vows of chastity and the renunciation of worldly possessions implied in profession, although not always strictly adhered to, could not possibly meet the need for transferring wealth within elite kinship networks."172 However, the fact that on a single day the Crown approved petitions for Francisca del Castillo, the daughter of the Third Marqués de San Felipe y Santiago, and Antonia de Contreras, the daughter of the First Conde de Gibacoa, to become protégés at Santa Clara suggest that factors other than the transference of wealth within kinship networks motivated Havana's elite. Castillo's father, the Third Marqués de San Felipe y Santiago (Juan Francisco Núñez del Castillo), was a large landowner and the titular head of the Núñez del Castillo clan. He served as captain in the

172 Lavrin, "Female Religious," 178-179. 
Havana volunteer infantry and later as captain of the cavalry militia of the city. ${ }^{173}$ Contreras' father, the First Conde de Gibacoa (Gerónimo Espinosa de Contreras y Jústiz) was a major landowner in Matanzas. He held a mayorazgo and investments in sugar, tobacco, lumber, and shipbuilding. In addition the Conde was an alcalde ordinario on the cabildo and colonel in the Matanzas dragoons, commanding the militia unit until his death in 1787. ${ }^{174}$ Antonia was one of at least seven daughters of the Conde, which probably explains her presence in the convent. ${ }^{175}$ One of her sisters, Ignacia Josefa de la Luz

173 Kuethe, Crown, Military, and Society, 52; Thomas, Cuba, 32; Nieto, Dignidades, 482.

174 Kuethe, Crown, Military, and Society, 58; Nieto, Dignidades, $250-251$.

175 Allan Kuethe notes that the Second Conde de Gibacoa (José María de Jesús Espinosa de Contreras y Jústiz y Zayas-Bazán) had to leave the army to attend to the family mayorazgo and his four unmarried sisters (Kuethe, Crown, Military, and Society, 120). Because Antonia de Contreras was a professed nun by 1787 , it is assumed she was not included in this number (For reference to Antonia de Contreras as a nun see AGI, SD 1142, Consulta, June 28, 1788). In addition, two of Antonia's sisters were married at the time of the Conde's death. Ignacia Josefa de la Luz Espinosa de Contreras $Y$ Jústiz married Juan Clemente Núñez del Castillo y Molina (the Fourth Marqués de San Felipe y Santiagol on October 12, 1772 and Maria de la Luz Espinosa de Contreras y Jústiz 
Espinosa de Contreras y Jústiz, married Erancisca del

Castillo's brother, Juan Clemente Núñez del Castillo, and

became the Fourth Marquesa de San Felipe y Santiago. ${ }^{176}$

Another sister, María de la Luz Josefa Espinosa de

Contreras y Jústiz, became the Second Baronesa de Késsel

through marriage and resided at court. ${ }^{177}$ A brother, José

María de Jesús Espinosa de Contreras y Jústiz y Zayas-

Bazán, succeeded her father as the second Conde de

Gibacoa. ${ }^{178}$

married José Késsel y Van Huffill (the Second Barón de Késsel) on June 29, 1782 (Nieto, Dignidades, 298, 482).

176 AGI, Ultramar 365, Agustin Josef [Illegible] to the Crown (on behalf of the Marquesa de San Eelipe $Y$ Santiago), August 16, 1796; Nieto, Dignidades, 482.

177 AGI, SD 1142, Consulta, June 28, 1788; Nieto, Dignidades, 298; Sherry Johnson says unlike creoles elsewhere in the Spanish empire, those in Cuba tended to remain plugged into Iberian kinship networks, which perhaps explains a marriage of this sort (M. Sherry Johnson, "Honor is Life": Military Reform and the Transformation of Cuban Society: 1753-1796" (Ph.D. diss. University of Florida, 1995), 296).

178 Kuethe, Crown, Military, and Society, 120; Nieto, Dignidades, 251-252. 
By June of 1778 Santa Clara had returned three of the four disputed second dowries. ${ }^{179}$ The Second Marqués Jústiz de Santa Ana (Manuel José Aparicio del Manzano y Jústiz) collected the second dowry of his niece, Sister Maria Catalina de San Gerónimo Guazo. ${ }^{180}$ The Marqués Jústiz de Santa Ana was a prominent citizen of Havana, serving as alcalde ordinario on the cabildo, Juez de Apelaciones (appellate justice) for the Province of Louisiana, and Contador Mayor del Real Tribunal de Cuentas (Chief Accountant of the Accounting Tribunal). The marquis' half-brother was the Conde de Gibacoa (Gerónimo Espinoza de Contreras y Jústiz). ${ }^{181}$ Laureano Chacón, an important landowner and an alcalde ordinario on the cabildo, who was empowered to act on behalf of Francisco Xavier Arriola, collected the second dowry of Arriola's daughter, Sister

179 AGI, SD 1422, an unnamed provincial in Havana to Manuel de la Vega, June 1, 1778, summarized in Manuel de la Vega's November 29, 1777 letter to the Council of the Indies, which is attached to the December 1, 1779 expediente of Diego José Navarro.

180 Ibid.

181 Kuethe, Crown, Military, and Society, 52, 58-59; Nieto, Dignidades, 294-295. 
María de Jesús Arriola. ${ }^{182}$ Nicolás Chacón, whose social status warranted a prestige appointment as captain of the volunteer cavalry regimen in 1763, collected the second dowry of his daughter, Sister Lugarda de la Natividad Chacón. ${ }^{183}$ However the community refused to pay Juan Guifano the equivalent of the second dowry of his daughter, Sister Clara de Santa María de Desamparados Guifano, on the grounds that both of his daughter's dowries were paid from a public limosna. On the grounds that "pious persons" had contributed the money specifically for his daughter to become a nun at the convent, the community retained it. ${ }^{184}$ Feeling he had a

182 AGI, SD 1422, an unnamed provincial in Havana to Manuel de la Vega, June 1, 1778, summarized in Manuel de la Vega's November 29, 1777 letter to the Council of the Indies, which is attached to the December 1, 1779 expediente of Diego José Navarro; Pablo Tornero, "Hacendados y desarrollo azucarero cubano (1763-1818)," Revista de Indias, nos. 153-154 (1978): 730; Kuethe, Crown, Military, and Society, 58.

183 AGI, SD 1422, an unnamed provincial in Havana to Manuel de la Vega, June 1, 1778, summarized in Manuel de la Vega's November 29, 1777 letter to the Council of the Indies, which is attached to the December 1, 1779 expediente of Diego José Navarro; Kuethe, Crown, Military, and Society, 183 .

184 AGI, SD 1411, Juan Barcelo to Manuel de la Vega, October 15, 1776, summarized in Manuel de la Vega's April 28, 1777 letter to the Council of the Indies, which is 
right to the money, Juan Guifano appealed to Governor Navarro. Navarro's efforts to help the father were stifled when Tomás Cervantes, the mayordomo of Santa Clara, invoked the ecclesiastical fuero, claiming that the matter fell under the jurisdiction of the ecclesiastical provisor. Despite the jurisdictional impediment, Navarro did manage to have the disputed amount, 2,150 pesos, placed on deposit with the royal hacienda, pending a resolution by the crown. ${ }^{185}$

That is where matters stood on July 13, 1779 when Navarro appealed to Madrid to resolve the matter. The governor did not dispute the community's assertion that the Iimosna had been collected in order for Clara Guifano to become a nun, but he contended that the 2,150 pesos "irrevocably" had been given to Clara, and that she had bequeathed the money to her father when she renounced all claims to it at her profession. Navarro argued that allowing the money to remain in the convent's coffers

attached to the August 7, 1777 expediente of Maria Loreto Ruiz.

185 AGI, SD 1422, Diego José Navarro to José de Gálvez, July 13, 1779. 
would go against the intentions of the benefactors and only enriched the community for its mistakes. More in line with the benefactors' intentions, he claimed, would be to return the money to the father, who could then use it to cover the "frequent and considerable" costs associated with his daughter's vocation. As examples of "frequent and considerable costs," the governor cited those associated with the many offices at the convent. ${ }^{186}$ After reviewing the governor's argument, the fiscal of the Council determined that both the governor and the ecclesiastical provisor had overstepped their authority. In a respuesta of October 23, 1779, the fiscal said that the commissary general alone, as superior of the nuns, was responsible for overseeing the reimbursement of the second dowries, adding that the cédula of October 19, 1777 had been intended only to have the governor give notice to those individuals who had paid the second dowries so that they could go to the convent to be reimbursed, not to make the governor a "judge" in the matter. Having concluded that the intention of those who contributed to the Iimosna, to whom he determined the money rightfully

186 Ibid. 
belonged, had been that Clara Guifano use the money to become a nun at the convent and also to sustain herself there, the fiscal recommended that the second dowry remain at Santa Clara where it could be invested and the proceeds used to cover Clara's needs during her lifetime. Upon her death the money was to go to the convent as her rightful heir. ${ }^{187}$ The Council resolved the matter on March 9, 1780, but not in accordance with the fiscal's dictum. It determined that the individuals who had contributed to Guifano's second dowry should have the option of being reimbursed. Only if the individuals did not wish to be reimbursed would the money be applied to the "religious needs" of the community. ${ }^{188}$ With this resolution, the issue of double dowries ceases to appear in the documentation.

Although resolved, the controversies surrounding supernumerary admissions and double dowries at Santa Clara

187 AGI, SD 1422, Respuesta of the fiscal, October 23, 1779, written in the margin of Diego José Navarro's July 13. 1779 letter to José de Gálvez.

188 AGI, SD 1422, Acuerdo of the Council of the Indies, March 9, 1780, attached to the December 1, 1779 expediente of Diego José Navarro. 
demonstrate the persistence with which elite families endeavored to have their daughters admitted to the novitiate at the convent. During the 1770 s these families foiled the efforts of the crown to shut the door on new admissions at the convent. However, as a new decade dawned the crown finally had Santa Clara's religious population under control and could turn its attention to reestablishing communal life at the convent. 
CHAPTER VI

THE RE-ESTABLISHMENT OF COMMUNAL LIFE, 1783

The long-awaited reply to Manuel Estéves' letter of August 4, 1781 came in a cédula of August 10, 1782. The decree, which enforced the cédula of May 22, 1774 at Santa Clara, assured Estéves the benefit of royal sanction that he had sought. With the benefit of royal backing, the vicar provincial began to make slow but certain progress in his efforts to reestablish communal life at Santa Clara. Between February and May of 1783, he worked diligently to make communal life a reality at the convent. For all of his efforts, however, Estéves could claim only nineteen converts when he reported his results to the Crown on May 8, 1783; but the meager harvest belies the tenacity of his efforts.

Estéves began plotting the re-establishment of communal life at Santa Clara in late January of 1783. Initially, the vicar provincial was reluctant to disclose the full details of the royal orders, preferring instead to wait until after the triennial elections scheduled for May. His reasons for withholding the details were twofold: some in the community, he reasoned, would adopt communal life simply as a means to an end, to fulfill 
their aspirations to hold office; while others, he worried, would be reluctant to embrace the communal regimen for fear that they would be suspected of harboring such aspirations. There were other matters to consider as well. Communal food was scarce and of poor quality, finances were poorly managed, and forty secular females and their servants continued to live at the convent. ${ }^{189}$ In early February of 1783 Esteves begin laying the groundwork for the re-establishment of communal ife at Santa Clara. On February 1 he ordered the abbess, Ana Antonia de la Natividad Albeja, and the contadoras of the convent to incur no "extraordinary expense," such as that associated with the purchase or refurbishment of fincas or fábricas, without his approval. At the same time he required that any surplus remaining after daily expenses be deposited in the arca de tres llaves. ${ }^{190}$ A week later, on February 8, he leaked to the abbess the article from

189 AGI, Cuba 1293, Manuel Estéves to the Crown, March $24,1783$.

190 Ibid. AGI, Ultramar 396, Auto of Manuel de Estéves (\#85), February 1, 1783, and Manuel Estéves to the abbess and nuns of Santa Clara (\#94), March 1, 1783, copies of which can be found in the May 16, 1783 testimonio of Josef Antonio Barrios. 
the cédula of 1774 which restricted the use of personal servants, instructing Albeja to bring her community into compliance with the article. That is the abbess was to alert those nuns who intended to embrace communal life to make preparations to release their personal servants and those who intended to continue in the private regimen to Iimit themselves to one servant. ${ }^{191}$ Albeja, who had many run-ins with Estéves since coming to power in March of the previous year, refused to obey the orders. ${ }^{192}$

Angered by the abbess' insubordination, Estéves broke with protocol. On February 17 he circumvented Albeja's authority by having the secretary of Santa Elena Province, José Rodriguez, convene the community with the assistance of the vicaria de la casa, Inés Gertrudis de San José Pita, one of only two officers who were supportive of communal life (the other being the maestra de novicias or

191 AGI, Ultramar 396, Auto of Manuel Estéves (\#86), February 8, 1783, and Manuel Estéves to the abbess and nuns of Santa Clara (\#94), March 1, 1783, copies of which can be found in the May 16, 1783 testimonio of Josef Antonio Barrios.

192 Ibid. 
the mistress of novices). ${ }^{193}$ once convened, Rodriguez read the article from the cédula of 1774 which restricted the use of personal servants, informing the sisters that they had "a month, more or less" to bring themselves into compliance with it. ${ }^{194}$

The obstinacy that the abbess and the other officers of Santa Clara displayed must be understood in the context of the community's membership. The meek and humble generally chose to confess at one of the other two convents of the city, either at Santa Teresa or at Santa Catalina. Santa Clara attracted the strong-willed, status-conscious, independent, and often outspoken daughters of the leading families of the city. ${ }^{195}$

193 I assume here that the vicaria de la casa is the equivalent of a priora (prioress). The prioress was second only to the abbess in authority, and the office often was used as a "stepping stone" to becoming abbess (Martin, Daughters, 264).

194 AGI, Ultramar 396, Auto of Manuel de Estéves (\#87), February 17, 1783, and Manuel Esteves to the abbess and nuns of Santa Clara (\#94), March 1, 1783, copies of which can be found in the May 16, 1783 testimonio of Josef Antonio Barrios.

195 For discussion of the social composition of a convento grande, such as Santa Clara see Martín, Daughters, 241-242. 
Sometime over the next two weeks, Estéves made the decision to disclose the full details of the royal orders, because on March 1 the pro-secretary of Santa Elena Province, José Antonio de Barrios, delivered copies of the Cédulas of August 10, 1782 and May 22, 1774 to the vicaria de la casa. The vicaria, in turn, had the convent's secretary make copies of the cédulas. The secretary then distributed copies to each of the nuns. Professed nuns, in accordance with the cédula of 1774, had two weeks, or until March 16, to decide for themselves whether they would enter into communal life or remain in the private regimen. Estéves set aside hours in the mornings and afternoons for professed nuns to consult with their male spiritual directors. Novices had no choice but to enter into communal life. ${ }^{196}$

The nuns had much to ponder. On March 1 they received a general summary of the vicar provincial's plan, which called for each nun to receive twenty-five pesos monthly. Any sister entering into communal life was to

196 AGI, Ultramar 396, Manuel Estéves to the abbess and nuns of Santa Clara (\#95), March 1, 1783, a copy of which can be found in the May 16, 1783 testimonio of Josef Antonio Barrios. 
have the twenty-five-peso mesada deposited on her behalf with the provisora, ropera, and depositaria (the nuns responsible for buying food, cloth to make habits and undergarments, and other basic necessities); whereas any sister opting to continue in private life was to have the twenty-five-peso mesada paid directly to her. The infirm were to receive additional support. Depending on the severity of the condition, an infirm nun would receive either an extra four or eight reales a week. Expenses associated with the sacristy, the aseo, the crypt, the doctor, the pharmacy, repairs to the convent, and other indivisible costs were to be covered with communal funds. ${ }^{197}$

The vicar provincial opted to close the kitchen, which had cost the convent 6,000 pesos annually to operate, pending the start of communal life. Until then the nuns were expected to buy lunch and dinner with "dinero de contado." When the kitchen did reopen, Estéves planned to operate it in such a manner that both those in

197 AGI, Ultramar 396, Manuel Estéves to the abbess and nuns of Santa Clara (\#96), March 1, 1783, a copy of which can be found in the May 16, 1783 testimonio of Josef Antonio Barrios. 
the communal and private regimens would share the facility. The closing of the kitchen angered the nuns but did little to alter their daily routine because so few ate there. However, the fact that the measure also denied the nuns access to the refectory caused an uproar because the community traditionally gathered in the refectory in the morning and at night for spiritual lessons. ${ }^{198}$

On March 17 the nuns received a detailed account of how rents would be distributed. The vicar provincial gave them until March 22 to review the information and render their decisions. On the designated day, a friar arrived at the convent to collect the decisions. ${ }^{199}$

The harvest was meager. When the votes were tallied, only thirteen professed nuns had opted to enter into communal life, which was scheduled to begin on April 1.

198 AGI, Ultramar 396, Manuel Estéves to the abbess and nuns of Santa Clara (\#95), March 1, 1783, a copy of which can be found in the May 16, 1783 testimonio of Josef Antonio Barrios, and Ana Antonia de la Natividad to the Crown, May 24, 1783; AGI, Cuba 1343, Rosa Maria de la Purisima Concepción Guilien to Luis de Unzaga, March 25, 1783.

199 AGI, Ultramar 396, Manuel Estéves to the abbess and nuns of Santa Clara (\#98), March 15, 1783, a copy of which can be found in the May 16, 1783 testimonio of Josef Antonio Barrios. 
Only two officers--the vicaria de la casa, Inés Gertrudis de San José Pita, and the maestra de novicias (mistress of novices), María de San José de Leon--were among the professed nuns who voluntarily adopted the regimen. ${ }^{200}$ The other eleven were: María Jesús de San José Arriola, Margarita de la Presentación Poveda, María Josefa de Jesís en el Huerto Guixano, Bárbara María de la Santa Corona de Leyba, Antonia de San Joaquín Tamayo, María Catalina de Santa Inés San Martín, Tomasa María de San Diego Coca, María Josefa de la Asunción Ayala, Juana de Jesús Nazareño Trevejo, Maria Concepción de Santa Margarita Acosta, and María Jesús de Santa Ana Arriola. ${ }^{201}$ The six novices who

200 AGI, Cuba 1293, Manuel Estéves to the Crown, March 24, 1783; The maestra de novicias was ranked in the upper echelon of officers of the convent, particularly because of the unmatched influence she enjoyed over the novices (Martin, Daughters, 264).

201 AGI, Cuba 1293, Manuel Estéves to the Crown, March 24, 1783; AGI, Ultramar 396, Inés Gertrudís de San José Pita (vicaria de la casa), Bárbara María de San José de León, (maestra de novicias), María Jesús de San José Arriola, Margarita de la Presentación Poveda, María Josefa de Jesús en el Huerto Guixano, Bárbara María de Santa Corona de Leyba, Antonia de San Juaquín Tamayo, María Catalina de Santa Inés San Martín, Tomasa María de San Diego Coca, María Josefa de la Asunción Ayala, Juana de Jesús Nazareño Trevejo, María Concepción de Santa Margarita Acosta, María Jesús de Santa Ana Arriola to Manuel Estéves (\#99), March 22, 1783, a copy of which can be found in the May 16, 1783 testimonio of Josef Antonio Barrios. 
were compelled to embrace the regimen were: Antonia de la Resurrección Contreras, María Josefa del Corazón de Jesús Domingues, María Josefa de San Antonio Pimienta, María Loreto de San Gabriel Ruiz, María de San Juan Nepomuceño Acosta, Maria Francisca de Santa Catalina de Bononía Guazo. 202

The decision split the community along socio-economic and familial lines. Although Estéves reported to the Crown on May 8 that the thirteen professed nuns who opted for communal life were of "distinguished birth," no daughter of a noble family appears among the names of those who voluntarily embraced the regimen. ${ }^{203}$ only among the novices, who had no choice but to enter into communal life, does the name of a nobleman's daughter appear: Antonia de la Resurrección Contreras, the daughter of the Conde de Gibacoa (Gerónimo Espinosa de Contreras y Jústiz). The daughters of the leading families of Havana,

202 AGI, Cuba 1293, Manuel Estéves to the Crown, March 24, 1783; AGI, Ultramar 396, Juramento of Ignacio de Ayala, March 22, 1783 (\#100), the original of which is found in the May 16, 1783 testimonio of Josef Antonio Barrios.

203 AGI, Ultramar 396, Manuel Estéves to the Crown, May 8, 1783. 
the great majority of the mature and merited nuns, and the community's most powerful and influential members--its abbess, difinidoras (members of the abbess' personal cabinet), and madres de consejo--opted to remain in private life. ${ }^{204}$

Having laid the groundwork for the re-establishment of communal life, Estéves sought to ensure its stability by tapping into what was perhaps the only readily available source of revenue: the entrance fees required of novices. On March 24 the vicar provincial made it more expensive to become a novice at santa clara. Customarily, novices deposited $1871 / 2$ pesos in the contaduria upon entering the convent $(1371 / 2$ which represented a fivepercent yield on a dowry of 2,750 pesos to cover the costs of room and board and fifty pesos to cover the costs of the infirmary). Having determined that the entrance fee had not kept pace with inflation and also recognizing that after April 1 novices would be living communally and receiving twenty-five pesos monthly (300 annually), Estéves mandated that entering novices deposit 300 pesos

204 The difinidoras formed a personal cabinet of the abbess, and their loyalty was essential to the abbess' success (Martin, Daughters, 263-264) 
with the depositaria of communal life. He required that the six current novices deposit a prorated amount: 300 pesos prorated from April 1 until their profession, or nine pesos and three reales more a month. The vicar provincial budgeted 252 of the 300 pesos to cover the costs of room, board, and community expenses, with the remaining forty-eight pesos going to cover the costs of the doctor and the pharmacy. A novice who chose to leave the convent during her probationary year would be reimbursed twenty-one pesos for each month she had prepaid under the vicar provincial's plan. The vicar provincial intended to use the additional four-pesos to cover the costs of the novices' clothing (i.e., habits, undergarments, and veils) and to apply toward the costs of caring for large number of sick in the infirmary. ${ }^{205}$ Moving quickly to reestablish communal life with little concern for protocol or custom, Estéves stirred fervent opposition among the nuns and their powerful

205 AGI, Cuba 1293, Manuel Estéves to the Crown, March 24, 1783; AGI, Ultramar 396, Auto of Manuel Estéves (\#101), March 24, 1783, a copy of which is found in the May 16, 1783 testimonio of Josef Antonio Barrios. 
families. ${ }^{206}$ It was customary during such periods of turmoil, to have brothers, uncles, and male cousins visit the nuns in the locutorios to give moral support. 207 on this occasion, the governor himself, Luis de Unzaga, visited the convent's locutorio to hear the complaints of the nuns and to offer his assistance. ${ }^{208}$

One of those who spoke with Unzaga in the locutorio was Sister Rosa de la Purísima Concepción Guillen. In a letter of March 25 Guillen reminded the governor of their conversation in the locutorio. Offering few specifics, Guillen reiterated that the provincial's actions had caused "many troubles to their souls" and implored Unzaga to suspend the introduction of communal life until one of three things occurred: either the nuns had the opportunity to appeal to the king; the community witnessed a reduction

206 AGI, Ultramar 396, Manuel Estéves to the abbess and nuns of Santa Clara (\#102), March 29, 1783, attached to the May 16, 1783 testimonio of Josef Antonio Barrios.

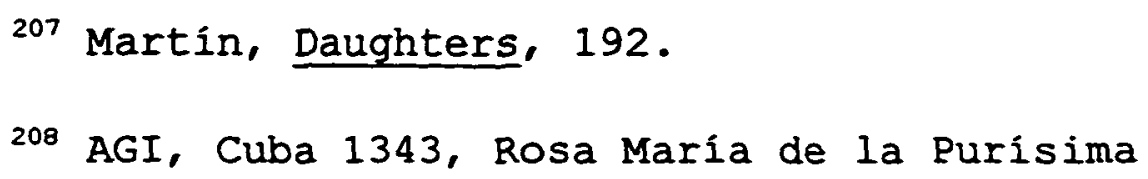


in its religious population; or else the War of American Independence (1776-1783) in which Spain and, thereby, Cuba was involved came to an end. ${ }^{209}$ Guillen asked that the governor see that the royal orders were executed in the benign spirit they were intended, thereby ensuring that all in the community were left in complete liberty to decide for themselves whether to embrace communal Iife. ${ }^{210}$

Recognizing that time was of the essence with the scheduled start of communal life only five days away, Unzaga was quick to respond to Guillen. The governor assured Guillen in a letter of March 26 that he had not forgotten their conversation in the locutorio. At the same time he disclosed to her his plan to convene a meeting of the vicar provincial, the bishop, and himself

209 AGI, Cuba 1343, Rosa María de la Purisima Concepción Guillen to Luis de Unzaga, March 25, 1783; Although Guillen, and later the superiors of Santa Clara, used the War of American Independence as an excuse for opposing the re-establishment of communal life, the war probably inflicted no hardship on the convent. After Spain followed the lead of France and Holland, entering the war on the side of the colonists, Havana enjoyed free commerce with Spain's allies, including the former British colonies of North America (Pérez, Between Reform and Revolution, 59).

210 AGI, Cuba 1343, Rosa María de la Purísima Concepción Guillen to Luis de Unzaga, March 25, 1783. 
in hopes of suspending the start of communal life until the Crown could weigh in on the matter. However, Unzaga stressed to Guillen that the community needed to put its charges in a formal representación, assuring her that upon receipt of that letter he would not delay in calling the meeting. ${ }^{211}$

The abbess and the officers of Santa Clara were happy to oblige Unzaga. On March 28 the superiors of the convent--the abbess, Ana Antonia de la Natividad, two madres de consejo, María Isabel de San Miguel and Agustina de Santa Coleta and three difinidoras, Bárbara de la Coronación, Manuela de San Francisco, and María de Santa Clara--filed a formal representación with the governor. They charged that the vicar provincial's purposely had threatened to deprive their community of "many things" previously administered communally in an effort to force the nuns to embrace communal life. According to the officers, each member of the community received a monthly monetary allotment of sixteen pesos and "everything else in kind, like food, veils, and several other things." The

211 AGI, Cuba 1343, Luis de Unzaga to Rosa María de la Purisima Concepción Guillen, March 26, 1783. 
sisters complained, likewise, that the reform was poorly timed. Chief among their concerns was that the War of American Independence might cause shortages and inflation, depleting the communal coffers and, thereby, making it "very difficult" to maintain the twenty-five pesos-mesada. payments. Another concern was that the mesada would be jeopardized by a chronic inability to collect rents from tenants. Santa Clara, although by no means unique in its inability to collect debts from tenants, seemed particularly cursed. In 1783, for example, outstanding rents totaled more than 34,000 pesos. ${ }^{212}$ Suggesting that the mix of ingredients made Santa clara ripe for a repeat of the debacle of 1769-70, the nuns asked the governor to suspend the start of communal life until "times improved

212 AGI, Ultramar 396, Ana Antonia de la Natividad (abbess), María Isabel de San Miguel (madre de consejo), Agustína de Santa coleta (madre de consejo), Bárbara de la Coronación (difinidora), Manuela de San Francisco (difinidora), María de Santa Clara (difinidora) to Manuel Estéves, March 28, 1783, and Ana Antonia de la Natividad (abbess), María Isabel de San Miguel (madre de consejo), Agustina de Santa coleta (madre de consejo), Bárbara de la Coronación (difinidora), Manuela de San Francisco

(difinidora), María de Santa Clara (difinidora) to Luis de Unzaga, copies of which are attached to the March 20, 1784 letter of Luis de Unzaga to the Crown sent via reservada; As noted above, it was not unusual during the colonial period for tenants to be years behind in their payments (Lavrin, "Female Religious," 180-182). 
and precautions [could be] taken to ensure the stability of such an important endeavor." If done in this manner, they assured the Unzaga, "all or the greater part of the community" would embrace communal life. ${ }^{213}$

With the formal representacion of the sisters in hand, Unzaga summoned the vicar provincial and the bishop to a meeting at his house on Monday, March 31 at 10 a.m. Also in attendance were two of Unzaga's advisors, the auditor de guerra and Erancisco de Acosta. In the meeting, which lasted only until noon, Estéves presented the governor with an oficio in which refuted each of the concerns raised by the nuns in their March 28 representación. ${ }^{214}$

213 The nuns sent similar representaciones to Vicar provincial Estéves and Bishop Hechavarría (AGI, Ultramar 396, Ana Antonia de la Natividad (abbess), Maria Isabel de San Miguel (madre de consejo), Agustína de Santa Coleta (madre de consejo), Bárbara de la Coronación (difinidora), Manuela de San Erancisco (difinidora), María de Santa Clara (difinidora) to Manuel Estéves, March 28, 1783, and Ana Antonia de la Natividad (abbess), María Isabel de San Miguel (madre de consejo). Agustina de Santa Coleta (madre de consejo), Bárbara de la Coronación (difinidora), Manuela de San Francisco (difinidora), María de Santa Clara (difinidora) to Luis de Unzaga, copies of which are attached to the March 20, 1784 letter of Luis de Unzaga to the (rown).

214 AGI, Ultramar 396, Luis de Unzaga to the Crown, March 20, 1784; AGI, Ultramar 396, Manuel Estéves to Luis Unzaga y Amezaga, March 31, 1783, and José Santiago de 
In his oficio Estéves countered the charge that his plan would deprive the majority of the nuns in private life of many things previously administered communally. He pointed out that the twenty-five-peso mesada 1300 annually) was more than the nuns currently received. Under the current system, each nun received sixteen pesos a month for food, twenty-seven pesos a year for habits and undergarments, and one real a week for veils, which totaled $2251 / 2$ pesos annually. ${ }^{215}$

In a similar fashion, Estéves dismissed the concern that war-time inflation, depleted coffers, and a chronic inability to collect rents would doom his plan. The vicar provincial stressed that during the previous year, which he labeled "very calamitous, and more so than the present," nineteen persons, with a couple of servants, could have lived comfortably in Havana on 475 pesos a

Hechavarria to Luis de Unzaga, April 8, 1783, copies of which are attached to the March 20, 1784 letter of Luis de Unzaga to the crown.

215 AGI, Cuba 1343, Manuel Estéves to Luis de Unzaga, March 31, 1783. 
month. ${ }^{216}$ Citing the fact that santa Clara's account books showed no evidence of the convent's coffers ever having been depleted by war time shortages and inflation, he stressed that he had no reason to believe anything of the sort would happen in the future. Likewise, he noted that with 34,000 pesos in rents outstanding, collections still had averaged 40,000 pesos annually during the previous three years of war, proving that any fear based on the inability to collect rents was unfounded. ${ }^{217}$

Estéves felt any comparisons of 1769-70 and 1783 were unfair and fruitless in light of the varying circumstances of the two eras and the fact that Madrid already was well aware of the earlier debacle. He pointed out that in 1769 the religious population of Santa Clara had exceeded 100 and the nuns were forced to enter into communal Iife; whereas in 1783, the religious population of the convent stood at ninety, rents had increased considerably over the previous fourteen years, and the decision to enter into

216 Estéves did not specify "a couple of servants," as I have, but his plan did call for one communal servant for every ten nuns.

217 Ibid. 
the communal regimen was, in Estéves' words, "purely voluntary." These factors, combined with the fact that the Crown long ago had been made aware of the events of 1769-70, led Estéves to dismiss such comparisons as irrelevant. ${ }^{218}$

Finally, Estéves dismissed the division and discord afflicting Santa Clara as an inevitable consequence of allowing two lifestyles, communal and private, to coexist under one roof. Because royal intentions had been to leave the nuns free to embrace or reject communal Iife, however, the vicar provincial lamented that there was Iittle he or the governor could do but look a generation into the future when attrition would dissipate all of the division and discord afflicting the community: as older nuns passed away, they would be replaced by novices who had no choice but to live communally. Although Estéves' oficio also included a plea that there the start of communal life not be delayed, royal and diocesan officials in attendance at the meeting deemed a delay necessary to allow for more time to review the status of Santa Clara's

218 Ibid. 
rents and the feasibility of the vicar provincial's plan. ${ }^{219}$

Having lost his bid to have communal life start as scheduled on April 1, the vicar provincial practiced damage control. Estéves assured the nuns on the afternoon of March 31 that "nothing was concluded" in the morning's meeting. Stressing that only the day set aside for the start of communal life had been changed, he assured the nuns "none of his orders given to date had been revoked or suspended." 220

Embittered and embarrassed to have to go before the community with news of the suspension, Estéves vented his frustrations to the governor in an oficio. In the oficio, which was delivered to the governor's house in the early morning hours of April 1, the vicar provincial complained that the delay had left the thirteen nuns and six novices in limbo. Contending that the crown had given him "no

219 Ibid. AGI, Ultramar 396, Luis de Unzaga to the Crown, March 20, 1784, and José Santiago de Hechavarría to Luis de Unzaga, a copy of which is attached to the March 20, 1784 letter of Luis de Unzaga to the Crown.

220 AGI, Cuba 1343, Manuel Estéves to Luis de Unzaga, March 31, 1783. 
reason, large or small" that would warrant a suspension or revocation of his orders, he called upon the governor to do one of three things: to respond immediately to his oficio of the previous day; to bring to fruition all of his orders given to date, including the one to start communal life; or to suspend his orders in their entirety pending a resolution by the crown. Taken aback by Estéves' impetuosity, Unzaga cautioned the vicar provincial in a letter of the same day that it was "grievous to labor more on this point," assuring the prelate that he would issue a reply only after he had time to reflect upon the oficio and consult with the bishop. ${ }^{221}$

In sharp contrast to Esteves, the officers of Santa Clara were elated by the events of March 31 and expressed their gratitude to Unzaga in a letter of April 2. Insisting that their community was not opposed to communal life but, rather, to the vicar provincial's methods, the officers labeled communal life "accommodating to [their] tranquilitty," "compatible with their state," and something that would "free [them] from concerns other than

221 AGI, Cuba 1343, Manuel Estéves to Luis de Unzaga, April 1, 1783; AGI, Cuba 1343, Luis de Unzaga to Manuel Estéves, April 1, 1783. 
[their] salvation." They defined "compatible" reforms as those that did not conflict with their Rules, Constitutions, or customs and which, at the same time, ensured the stability of the regime and prevented a repeat of the debacle of 1769-70.222 The officers' arguments were supported by a contadora of the convent, Francisca de Santa Catalina Bononía. On April 3 Bononia confirmed for the governor that Santa Clara's rents were insufficient to support seventy-one nuns in communal life. ${ }^{223}$

As the days passed, with no resolution in sight, Estéves lashed out at both the governor and the bishop. Believing his gains were being squandered, the vicar provincial argued in an April 4 letter to Unzaga that there was "no reason, large or small to reverse, much less to suspend even for one instant the establishment of communal life that the king had ordered [him] to establish

222 AGI, Cuba 1343, Ana Antonia de la Natividad (abbess), María Isabel de San Miguel (madre de consejo), Agustina de Santa Coleta (madre de consejo), Bárbara de la Coronación (difinidora), Manuela de San Erancisco

(difinidora), María de Santa Clara (difinidora) to Luis de Unzaga, April 2, 1783.

223 AGI, Cuba 1343, Erancisca de Santa Catalina Bononía to Luis de Unzaga, April 9, 1783. 
at the convent."224 Three days later, on April 7, he turned conciliatory toward the governor, agreeing to take no further action without his approval or that of the bishop (according to the vicar provincial, he made the same pledge verbally to the bishop two days earlier).$^{225}$ Having begrudgingly reconciled himself to the will of Unzaga, Estéves directed his ire at the bishop, accusing Hechavarria in an April 9 letter of undermining his efforts to reestablish communal life at the convent. ${ }^{226}$ Two more weeks of stalemate led Estéves to rethink his strategy. Convinced that his plan to allot each nun twenty-five pesos monthly had far greater support than the officers of the convent claimed, the vicar provincial decided to hold a referendum on his plan. On April 23 he instructed the nuns to write one of two statements on a

224 AGI, Cuba 1343, Manuel Estéves to Luis de Unzaga, April 4, 1783 .

225 AGI, Ultramar 396, Manuel Estéves to Iuis de Unzaga, April 7, 1783, a copy of which is attached to the March 20, 1784 letter of Luis de Unzaga to the Crown.

226 AGI, Ultramar 396, Manuel Estéves to José Santiago de Hechavarría, April 9, 1783, a copy of which is attached to the March 20, 1784 letter of Luis de Unzaga to the crown. 
small piece of paper: "I find the new distribution better," if they preferred his plan; or "I find the old distribution better," if they preferred the current allotment (sixteen pesos monthly for food, twenty-seven pesos annually for habits and undergarments, and one real a month for veils). He gave the nuns seven days, or until the afternoon of April 30, to make their election. ${ }^{227}$ In the interim, however, Estéves received permission to begin communal life at the convent. On April 28, with no mention of having come to any agreement or settlement with the governor and/or the bishop, the vicar provincial informed the nuns that communal life would begin three days hence, on May $1 .{ }^{228}$ when the results of the referendum were tallied, the overwhelming majority had scribbled "I find the new distribution better," meaning that communal life would begin with the twenty-five-peso

227 AGI, Ultramar 396, Manuel Estéves to the abbess and nuns of Santa Clara (\#105), April 23, 1783, attached to the May 16, 1783 testimonio of Josef Antonio Barrios.

228 Ibid. AGI, Ultramar 396, Manuel Estéves to the abbess and nuns of Santa Clara (\#106), April 28, 1783, attached to the May 16, 1783 testimonio of Josef Antonio Barrios. 
mesada. ${ }^{229}$ With only a meager harvest and the finer details still to be hammered out, the vicar provincial could, nonetheless, report to the Crown on May 8, 1783 that he had reestablished communal life at Santa clara after an absence of more than a century. ${ }^{230}$

Estéves' meager harvest is not surprising in light of similar results achieved by reformers in Mexico. There the majority of nuns exercised the option afforded to them in the cédula of May 22, 1774, by choosing to remain in private life. Of the 284 nuns under the jurisdiction of the Bishop of Puebla, Victoriano López, for example, only 123 embraced communal life. In Oaxaca not a single nun in the Convent of La Concepcion opted for the communal regimen. At the Convent of Santa Catalina de Sena of Mexico City, only seven of the community's sixty members abandoned private life. Not a single member of the community of Santa Clara of Querétaro embraced communal life. And the Archbishop of Mexico concluded that none of

229 AGI, Ultramar 396, Manuel Estéves to the abbess and nuns of Santa Clara (\#107), May 6, 1783, attached to the May 16, 1783 testimonio of Josef Antonio Barrios.

230 AGI, Ultramar 396, Manuel Estéves to the Crown, May 8, 1783 . 
the 601 nuns under his jurisdiction really were in favor of the communal regimen. 231

In Mexico nuns protested vehemently the cédula of 1774 in the immediate aftermath of its issuance. By the latter half of 1775, however, sensing the futility of their protests (the Crown had refused to consider any more petitions for exemption from communal lifel, many nuns acquiesced in the inevitable and embraced communal life. But the hopes of the disenchanted were rekindled in 1777 . Encouraged by mixed messages coming from the Crown, which at times issued cédulas in benefit to the nuns and at other times in favor of the reformers, female religious throughout Mexico began protesting communal Iife once again. ${ }^{232}$ However, the status quo seemingly changed very little over the next few years. In 1781 a survey of calzada convents in Puebla showed that only 119 out of 244 nuns had embraced communal life. Finding no follow-up to the 1781 survey, Lavrin suggests: "This lack of records leads one to think it apparently remained a local problem

\footnotetext{
231 Lavrin, "Reformation of Nunneries," 196-199.

232 Ibid., 197-198; Earriss, Crown and Clergy, 45.
} 
between nunneries and prelates, and no longer involved the higher echelons of the civil authorities as the interest in reformation gradually decreased, especially after the death of Charles III."233

In contrast with conventual reform in Mexico, its counterpart in Havana after 1781 involved the "higher echelons of the civil authorities" to a greater degree than ever before. The effort to reestablish communal ife at Santa Clara only began to bear fruit in 1783 . Thereafter, the Crown remained involved in the effort to reform the observant Eranciscan community to prevent a repeat of events of the $1770^{\prime}$ 's when the Havana elite worked to undermine the efforts of reformers. Progress would not follow a linear pattern after 1783. There would be setbacks, but as long as the crown was involved there was sure to be progress as well. As difficult a task as the re-establishment of communal life had been, the real work lay ahead. Maintaining the regimen against the will of the majority would prove even more difficult. With the Crown involved, however, progress would be slow but certain.

233 Lavrin, "Reform of Nunneries," 200. 
CHAPTER VII

SLOW BUT CERTAIN PROGRESS, 1784-1796

Communal life, reestablished on May 1, was assured continuity in the triennial elections of June 7. In early summer 1783 the Council of the Indies could take comfort in knowing that at the helm of the observant Franciscan community were officers who were supportive of communal life. Optimism that the transition had occurred without a hitch diminished, however, when letters from the exofficers of Santa Clara began trickling into Madrid. In August of 1783, the Council of the Indies received a distressing letter from the ex-abbess of the convent. Six months later, in February of 1784, the tribunal received a letter from the ex-difinidoras of the community who, like the abbess they had served, condemned all that had transpired at Santa clara in the name of reform. Although the Council of the Indies dismissed the clamoring in 1784, the tribunal would revisit the 1783 letter of the abbess a dozen years later in 1796.

In the summer of 1783 the Council of the Indies received conflicting reports from Havana. When Bishop Hechavarria, in a letter of June 20, 1783, praised the application of the cédula 1774 as an "authentic testament 
to the crown's wisdom, prudence, justice, and fairness," and a "monument of the rational use of sovereign power" and, at the same time, reported that communal life was off to a "good start." (feliz principio), the council had reason to be optimistic."234 However, that optimism was tempered in early August when it received a letter written by the ex-abbess of Santa Clara, Ana Antonia de la Natividad Albeja. In the letter, dated May 24, 1783, which was written in the interim between the start of communal life on May $I$ and the triennial elections of June 7. Albeja complained that Manuel Estéves' had violated the benign spirit of the cédula of August 10, 1782. The exabbess charged the vicar provincial with causing internecine battles in the community, which left the nuns "without the unity that [they] should have had as sisters"; ending "the only mode of communal life that [they] were permitted to practice in [those areas] where there [was] not the food or provisions that there [were]

234 AGI, Ultramar 396, José Santiago de Hechavarría to the Crown, June 10, 1783. 
in other parts"; and forcing her to vacate her cell and trying to remove her from office. ${ }^{235}$

While conceding that the Discalced Carmelite and Recollect Dominican communities of the city practiced a more perfect form of communal life than did her community, the ex-abbess pointed out that her male brethren did not. Albeja was angered by what she perceived to be a double standard, charging that the same friars who were trying to impose communal life upon the nuns did not practice the regimen themselves, despite the fact that they enjoyed considerable resources derived from limosnas, memorias, capellanias, and paid masses. The also received more than adequate food rations. Senior priests (padres graduados) received "crude" rations, double rations of bread, and five pesos each month for chocolate. The provincial received even more: triple bread rations and eight pesos monthly for chocolate. ${ }^{236}$

Although the situation Albeja described was neither optimal nor desirable, her letter failed to evoke a

235 Ultramar 396, Ana Antonia de la Natividad to the Crown, May 24, 1783.

236 Ibid. 
sympathetic response from the Council. The tribunal did not question the authenticity of the charges; for it already had in its possession letters corroborating the charges. Nonetheless, it dismissed the situation at Santa Clara as the inevitable consequence of reestablishing communal life in accordance with royal cédula of May 22, 1774. The tribunal's fiscal even suggested that the nuns should expect to suffer "some extortion and violence" in the re-establishment of communal life and judged it best to "conceal for now ... any inconvenience or restlessness (movimiento), having no other means to complete the king's will" (the "king's will" here being to leave the nuns in complete liberty to embrace or reject communal life and to limit suffrage and office-holding rights only to those who opted to embrace the communal regimen). The council took no action in response to Albeja's charges but did consult the commissary general, who objected to several of the vicar provincial's measures and generally supported the abbess. 237

237 AGI, Ultramar 396, Respuesta of the fiscal, August 29, 1783, and Manuel de la Vega to the Council of the Indies, November 6,1783 . 
Six months later, on Eebruary 12, 1784, the Council received another distressing letter, this one from the exdifinidoras of Santa Clara. The letter was written on June 14, 1783, only one week after the elections of June 7, 1783.238 Francisca de la Santa Catalina (an exdifinidora), María de Santa Clara (ex-difinidora), Josefa de la Santísima Trinidad (ex-difinidora), and Nicolasa de San Francisco (ex-difinidora) complained of the fact that the seventy-six in private life were precluded from participating in the elections. They asked the crown to restore suffrage and office-holding rights to the majority, arguing that the officers elected on June 7 did not merit their positions. They based this argument on the contention that many among the seventy-six in private Iife were more qualified on the bases of accomplishment, age, experience, and character to hold office at the convent. Their proposed solution to the dilemma mimicked the compromise reached by their male brethren to end strife between Creoles and Europeans: they suggested that offices be rotated every three years between those in

238 AGI, Ultramar 396, Respuesta of the Fiscal, August 7,1785 . 
communal life and those in private life, until attrition depleted the ranks of the latter. ${ }^{239}$

The Council was slow to act on the nuns' proposal, allowing almost three years to pass before even consulting the commissary general on the matter. ${ }^{240}$ By the time it finally did get around to consulting the commissary general in 1787, Manuel Maria Trujillo had succeeded Manuel de la Vega in the commissariat. Trujillo had gained considerable experience with the re-establishment of communal life in his capacity as provincial of the Franciscan province of Granada, a province in which there were twenty-seven female communities under Franciscan jurisdiction. There Eranciscan provincials attempted to reestablish communal life on three separate occasions. On each occasion the regimen failed to take root. As a result of a 1772 attempt to reestablish communal life, the

239 AGI, SD 2241, Carta de Francisca de la Santa Catalina (an ex-difinidora), María de Santa Clara (exdifinidora), Josefa de la Santisima Trinidad (exdifinidora), Nicolasa de San Erancisco (ex-difinidora) to the Crown, June 14, 1783.

240 AGI, Ultramar 396, Respuesta of the fiscal, August 7, 1785, and the Council of the Indies to Manuel Maria Trujillo, March 23, 1787. 
female communities of the province poured money into renovating the kitchens and the refectories in their convents and indebted themselves in the process. Trujillo's predecessor in the office of provincial returned eleven convents to private life. Trujillo, upon taking office, returned the remaining sixteen to the private regimen. ${ }^{241}$

Although a firm believer in the spiritual value of communal life, Trujillo thought it feasible only under certain conditions. He believed it feasible for those convents that had adhered to the regimen since their founding, since the remote past, or at least since the profession of the current membership. He thought it impractical for those convents founded in private life, for those in which private life had been the custom since "time immemorial," or for those in which rents were insufficient to support communal life. ${ }^{242}$

By 1787 Santa Clara was reeling financially and socially from the reforms. It already had become apparent

\footnotetext{
241 Ibid.

242 Ibid.
} 
that communal resources could never support the entire community in communal life. Furthermore, discord and division stemming from restrictions on political participation continued to afflict the community. Trujillo's solution was threefold. First, he proposed reducing the religious population of Santa Clara to seventy: fifty nuns of the black veil and twenty lay sisters. Until such a reduction was achieved, he suggested limiting the admission of novices to one for every five nuns that died. Such a policy, he believed, would ensure that there would always be nuns to fill the lower conventual offices, those which required strength and agility. Secondly he recommended that "a large portion of the black and mulata servants" be expelled, deeming their presence among the nuns "detrimental to the routine and even the honor of the convent" and blamed this underclass for cultivating a negative image of the nuns in civil society, suggesting that these individuals, "not subject to the cloistered life, go out into the world when they feel like it...[where] they exaggerate the slightest imperfections of the nuns and publicize their defects..." Finally, the commissary general proposed reintegrating that portion of the community that clung to the custom of 
private life. The older, merited nuns continued to look upon the younger officeholders as usurpers of the honor and authority that was rightfully theirs. He recommended that full suffrage and office-holding rights be restored to those in private life, believing that such a gesture would restore peace to the cloister and provide the community with much-needed leadership. ${ }^{243}$

The fiscal of the Council of the Indies was supportive of Trujillo's proposals, calling a community comprised of fifty nuns of the black veil "respectable."244 The official also saw the value of reintegrating those in private Iife but stressed that they should only be allowed to hold office as difinidoras, contadoras, vicaria de la casa, and madres de consejo. The abbess, he reasoned, should always serve as an example for the rest. It is not known whether the fiscal's 1787 recommendations were ever incorporated into a consulta or cédula. While commissary General Trujillo did order the religious population of the

243 AGI, Ultramar 396, Manuel María Trujillo to Antonio Ventura de Taranco, March 29, 1787.

244 AGI, Ultramar 396, Respuesta of the fiscal, November 8, 1787 . 
convent to be reduced to seventy, there is no evidence that suffrage and office-holding rights were restored to those in private life.

A decade passed before the Council revisited the issue of communal life at Santa Clara, its interest sparked by the discovery of the May 1783 letter of Ana Antonia de la Natividad Albeja among the papers of the former secretary of the tribunal, Antonio Ventura de Taranco. ${ }^{245}$ In the interim between fiscal's respuesta of 1787 and the rediscovery of Albeja's letter in 1796, the community had taken it upon itself to reduce further its target population. With mesada payments running three months behind in 1788, the nuns convened a meeting. Attended by the abbess, discretas, mayordomo, and provincial, the meeting resulted in an agreement to reduce the number of nuns at Santa clara to sixty-five, a number that matched the number of cells at the convent. ${ }^{246}$ The

245 AGI, Ultramar 396, Council of the Indies to Pablo de Moya, July 27, 1796.

246 AGI, Ultramar 396, Pablo de Moya to Erancisco Cerdá, August 20, 1796; Manuel María de Trujillo (Copy), November 5, 1788, attached to the August 20, 1796 letter of Pablo de Moya to Francisco Cerdá. 
primary motivation behind the reduction was economic: a religious population of sixty-five was more in line with what rents could support. However, there was a social benefit as well: if the number of nuns did not exceed the number of cells, disputes that frequently arose from the competition for a deceased nun's cell would be avoided. ${ }^{247}$ By 1795, however, Santa Clara's financial situation had deteriorated even further. Mesada payments were three months behind, due in part to a continued inability to collect from tenants. Much-needed repairs to the convent and the church went neglected. On a positive note, the convent's population had been reduced to eighty and approximately one-half of that number reportedly observed communal life. ${ }^{248}$

247 AGI, Ultramar 396, Pablo de la Moya to the Crown, November 5, 1788 (copy), attached to the August 20, 1796 letter of Manuel Maria Trujillo to the Council of the Indies; Huerta says the reduction to sixty-five was settled upon in 1787 (Huerta, "Monacato femenino en Cuba," p. 501).

248 Angel Huerta suggest that the figure given by the commissary general, that one-half of the community was living communally in 1795 may have been exaggerated (Huerta, "Monacato femenino," 502). I have found no reason to doubt the accuracy of the estimate. 
The notable reduction in the convent's population was about to fall victim to international politics. In the Treaty of Basle (1795), Spain ceded Santo Domingo to France. In October of that year, word reached Santo Domingo of the impending transfer, sparking an exodus that would total 125,000 people, one-third of the island's population. Those fleeing went to Cuba, Puerto Rico, and Venezuela. ${ }^{249}$ Twenty-five nuns from Santa Clara of Santo Domingo migrated to their sister community in Havana, bringing with them their personal servants. ${ }^{250}$ The migration compromised the two most tangible gains of the reform--the reductions of Santa Clara's religious and servant populations--and deteriorated further the financial situation at the convent. International politics were not the only threat to Santa Clara in the mid-1790s as Crown-sponsored educational reforms

249 Frank Moya Pons, "Haiti and Santo Domingo," in Cambridge History of Latin America, 8 vols., ed. Leslie Bethell (Cambridge: Cambridge University, 1985), 3: 245.

250 AGI, SD 1497, Gertrudis del Corazón de Jesús Morodo (abbess of the community of Santo Domingo) to Fernando Portillo y Torres, July 23, 1798. 
threatened to balloon the number of young girls living at the convent. 


\section{CHAPTER VIII}

REDEFINING THE ROLE OF THE CONVENT, 1796

Young girls had been educated in American convents since the sixteenth century. Nuns traditionally taught sewing and cooking skills along with simple math, reading, and writing. Some more opulent convents placed a great emphasis on voice, music, and even drama lessons. ${ }^{251}$ Prior to the Enlightenment, however, relatively few females had access to education. ${ }^{252}$ In the early eighteenth century, colonial society became more receptive to the idea of female education. By late century, the social and economic elite actively supported the founding of schools for girls. ${ }^{253}$ With no female colegio in Havana, the elite of the city increasingly turned to the nuns of Santa Clara to educate its daughters. The convent admitted protégés (young girls who entered with the desire to become nuns)

\section{Martín, Daughters, 79.}

252 Commenting on the education of females in convents prior to the eighteenth century, Asuncion Lavrin writes: "these efforts to educate women were neither systematic nor socially broad enough to make an appreciable impact on the total female population" (Lavrin, "Women and Religion," 47).

$$
253 \text { Ibid. }
$$


but not pupils (young girls who entered solely for the purposes of an education). Accordingly, petitions from the elite of the city commonly expressed a desire on the part of the aspirant to ultimately enter the novitiate at the convent. Bourbon officials, who measured the worth of the Church and its clergy in terms of social utility, accommodated members of the elite, regularly approving petitions for their daughters to enter Santa Clara as protégés. ${ }^{254}$

Until 1793, Eranciscan prelates acquiesced in the Crown's desire to appease the Havana elite by conceding licenses for young girls to enter the convent. In that year, however, the acquiescence came to an abrupt end when Commissary General Juan de Troya refused to admit a young habanera to Santa Clara, citing restrictions in ecclesiastical law and recent efforts of the observant Franciscan community to reduce its population. Not to be discouraged, the Crown sought and acquired a papal brief in 1795 that dispensed with all ecclesiastical

254 Nancy Earriss says that the Spanish Bourbons, particularly Charles III, "evaluated the Church and the clergy in terms of their contribution to economic progress and maintenance of empire" (Farriss, Crown and Clergy, 99). 
restrictions on the admission of young girls at all

American convents, thus opening the door for the admission of pupils at Santa Clara. ${ }^{255}$

On June 20, 1793 Commissary General Juan de Troya breached the issue of whether regular prelates had the authority to concede licenses for protégés to enter Santa Clara. On that day he refused to concede a license for María Rafaela Garrido y Cabello, the orphaned ten-year-old daughter of Josef Garrido and Bernarda Cabello, to enter the convent as a protégé. ${ }^{256}$ In refusing to concede the Iicense to Garrido y Cabello, Troya argued that ecclesiastical law had "restricted in great part" his authority in this area. His argument was not original but, rather, was copied from a discourse Eranciscan

255 In Spanish, the term "educanda" is used denote both protégé and pupil. For the sake of clarity, I make a distinction that does not exist in Spanish. Clearly, the intention of the Crown in acquiring the papal brief was to open the doors to pupils, not protégés. The admission of the latter only would have resulted in more novices, which was clearly not the Crown's intention.

256 AGI, Ultramar 365, Juan de Troya to Pedro Acuña, June 20, 1793; In some areas of Peru, the pre-requisite of a papal license had been dropped during the first decades of the seventeenth century. Thereafter, the consent of the local bishop was all that was required to admit a young girl at a convent (Martín, Daughters, 75). 
Commissary General Manuel de la Vega had penned sixteen years earlier, in 1777 , on the authority of regular prelates to admit retirees at Santa Clara. ${ }^{257}$

In January of 1777 the question of whether regular prelates had the authority to concede licenses for retirees to enter Santa Clara came to the fore when the Council had received a petition from Manuel de Insurieta. In the letter, Insurieta asked that Francisca Guazo, an orphan of noble lineage, be allowed to solicit a papal brief so that she could enter Santa Clara as a retiree with the benefit of a personal servant. ${ }^{258}$ Royal law, at the time, required that any subject who wanted to solicit a papal brief or bull first petition the crown for permission. ${ }^{259}$ Therefore, Guazo was following correct procedure when she sought the Council's permission to

257 AGI, SD 1465, Manuel de la Vega to the Council of the Indies, March 17, 1777, attached to the January 11, 1777 expediente of Francisca Guazo (\#3).

258 AGI, SD 1465, Manuel de Insurieta to the crown (on behalf of Erancisca Guazo) May 31, 1777, attached to the January 11, 1777 expediente of Erancisca Guazo (\#3).

259 AGI, SD 1465, Respuesta of the fiscal, January 31, 1777, attached to the January 11, 1777 expediente of Francisca Guazo (\#3). 
petition Rome. She also was following correct procedure with regard to ecclesiastical law. In 1777 , as in 1793, a papal license was required to admit any secular female at an American convent. However, the Council of the Indies determined that Guazo need not petition Rome to be allowed to enter Santa Clara, having concluded that royal law permitted a bishop--or in the case of Santa Clara a Eranciscan commissary general or a provincial--to concede the license Guazo sought. The only restrictions the Council recognized were those found in chapter six of Pinedo's reglamento, which mandated that the combined total of protégés and retirees at the convent not exceed fifteen and that there be only one servant for every ten nuns. Under the circumstances, the commissary general simply had to determine if there was a vacancy in the fifteen secular huecos, gauge the sentiment of the community and, if he found no impediment or objection to Guazo's admission, concede the sought-after license. Although chapter six of the reglamento did not address the right of a retiree to enter Santa Clara with a personal servant, the Council determined that the approval of the 
commissary general and its own permission were sufficient pre-requisites to admit a servant as well. ${ }^{260}$ The tribunal sent word of its decision to Commissary General Vega on February 22, 1777.261

In response to the Council's resolution, Manuel de la Vega, in a letter of March 8, 1777, admitted that bishops, commissary generals, and provincials could grant licenses for communal servants, protégés, and even retirees to enter convents, if the latter was a woman "de calidad" who was separated from her husband or the victim of spousal abuse, or if the aspirant was a noblewoman who was widowed and lacked the means to maintain herself properly. However, he argued that this authority did not permit him to concede license to a retiree under normal circumstances, and particularly not under the conditions that Guazo sought admission (i.e., with the benefit of a personal servant and also the right to be interred in the convent's crypt). Vega argued that the authority he

260 Ibid.

261 AGI, SD 1465, a note dated February 3, 1777, written at the end of the January 31,1777 respuesta of the fiscal. 
derived from royal law was "restricted in great part" by ecclesiastical prohibitions. Although acknowledging that his predecessor, Plácido de Pinedo, had established a maximum number of secular females that could be admitted at Santa Clara, Vega argued that the authority to set a maximum allowable limit and the authority to actually admit secular females were not one and the same.

The commissary general cited a host of ecclesiastical restrictions on his authority to concede a license for a secular female to enter the convent. Included among these were restrictions found in tridentine and canon law and in papal decrees. Until the second quarter of the eighteenth century, Rome did little to restrict the admission of secular females at American convents. Beginning with the papacy of Benedict XIV, however, the Vatican began to associate the failure of nuns to observe good monastic discipline with the large numbers of secular females in their midst. Of particular concern to Vega were bulls of Benedict XIV dated June 5, 1741 (cum sacrarum virginum), January 3, 1742 (salutare in catholica ecclesia institutum), and January 24, 1747 (per binas alias nras). These prohibited any secular female, regardless of whether she was a protégé, retiree, or servant, from entering a 
convent without a papal license and just cause, which could only be determined by a bishop or an archbishop, not by a regular prelate. There also were restrictive measures found in the patentes of a predecessor. Commissary General Matías de Velasco, in patentes of February 16, 1753 and September 16, 1760, prohibited the admission of secular females at Franciscan convents without a license of the pope or, in an apparent concession to the Crown, "of whomever might have the legitimate authority." Finally, chapter thirteen of the order's Constitutions contained an article prohibiting the admission of secular females at the convent without papal approval. 262

In response to the commissary general's discourse on ecclesiastical jurisdiction, the fiscal of the council of the Indies offered his own on the royal prerogative to admit retirees at American convents. Dismissing the midcentury bulls of Benedict XIV as inconsequential on the basis that they had never been submitted to the Council for approval, he suggested that they never would have been

262 AGI, SD 1465, Manuel de la Vega to the Council of the Indies, March 17, 1777, attached to the January 11, 1777 expediente of Erancisca Guazo (\#3). 
approved had they been submitted. For a bull to become law in the Americas, the patronato required that it first be approved by the Crown. ${ }^{263}$ Rome could never impede the admission of retirees in American convents in the fiscal's estimation "because it corresponded to civil government and to the conservation of the monarchy." "In the Indies," he said, "more than in any other part it is convenient and conducive for honest women of quality and orphans to have the opportunity to retire at a female convent."264 On May 10, 1777 the Council, which already had in its possession papal briefs granting sisters Rosalía and Brigida de Jesús Manso de Contreras permission to enter Santa Clara as retirees, adopted the fiscal's recommendation and informed the commissary general of its resolution. ${ }^{265}$ Commissary General Vega acquiesced in the royal prerogative, granting a license for Guazo,

263 AGI, SD 1465, Respuesta of the fiscal, April 29, 1777, attached to the January 11, 1777 expediente of Francisca Guazo (\#3).

264 Ibid.

265 AGI, SD 1465, Acuerdo of the Council of the Indies, May 10, 1777, written at the end of the April 29, 1777 respuesta of the fiscal. 
accompanied by a servant, to enter Santa Clara at the first vacancy in the secular huecos. ${ }^{266}$

Vega's successor in the commissariat, Manuel María de Trujillo, recognized no ecclesiastical impediment to the admission of retirees or protégés at Santa Clara. Trujillo objected to the admission of personal servants, supernumerary nuns or to that of an aspiring protégé who sought the benefit of a personal servant or the right to profess as a supernumerary nun, as opposed to waiting for a vacancy to occur. An important factor in the commissary general's decision to allow a young girl to become a protégé at Santa Clara appears to have been the presence of a relative (or relatives) at the convent, which is not surprising because nuns traditionally raised and educated nieces as a favor to their married brothers or sisters. ${ }^{267}$ A second important factor in Trujillo's decision were the circumstances under which the aspirant sought admission.

266 AGI, SD 1466, Expediente of Francisca del Castillo (\#8), February 5, 1778; Acuerdo of the Council of the Indies, February 9, 1778, written at the end of the expediente of Francisca Castillo and Expediente of Antonia Contreras (\#9), February 5, 1778 .

267 Martin, Daughters, 75. 
A young girl in particularly dire circumstances might arouse the sympathy of the commissary general. And on the occasion that she did not, and the Crown thought it warranted, Madrid was apt to override the prelate's decision and admit the aspirant, as it did in the case of Cecilia Josefa de Moya. ${ }^{268}$

Cecilia Josefa de Moya was the seventeen-year old daughter of Diego Miguel Moya, the oidor honorario (honorary alderman) of the Audiencia of Guatemala and asesoria general (consul general) of the Intendencia of Havana. After many years of trying unsuccessfully to gain admission to Santa Clara, young Moya appealed to the Crown on May 22, $1788 .{ }^{269}$ Her prospects for admission had grown worse with the 1788 decision of the Eranciscan community to reduce its religious population to sixty-five, a population which exactly matched the number of cells at the convent. Eurther compromising her prospects for a religious vocation was her age: at seventeen, she was too

268 AGI, SD 1142, Consulta, December 10, 1788.

269 AGI, SD 1473, Cecilia Josefa de Moya to the Crown, May 27, 1788, attached to the August 7, 1788 expediente of Cecilia Josefa de Moya. 
old to enter as a protégé (protégés entered between the ages of seven and twelve) and should have entered the novitiate the previous year. Her lot in life also recently had worsened, as a result of the "arresto" of her father. With her mother deceased, the arresto took on added significance. ${ }^{270}$

Although Moya had the support of Governor Luis Peñalver Cardenas and, more importantly, of the majority of the Observant Franciscan community, Commissary General Trujillo opposed her admission to santa clara. In a September 1, 1788 letter to the Council Trujillo urged the tribunal to deny Moya's petition, saying that her admission was contrary to the community's initiative to bring its population in line with the number of cells at the convent and also threatened the survival of communal life. The fact that Moya had a dowry was of little consideration to Trujillo. The commissary general contended that the financial needs of a seventeen-year old over her lifetime were sure to outdistance the yield on her dowry. He concluded by reminding the Council that

270 AGI, SD 1473, Luis Peñalver y Cardenas to the Crown, May 301788 , attached to the August 7, 1788 expediente of Cecilia Josefa de Moya. 
virtually every nun at Santa Clara had contributed a similar dowry, and yet the community still found itself "exorbitantly in arrears" (un atraso exorbitante)."271 However, in light of Moya's age and circumstances, the Council felt something had to be done and recommended a compromise. In a consulta of December 10,1788 the tribunal suggested that Moya occupy a secular hueco until a vacancy occurred in the novitiate, a measure which the Crown approved on January 17, 1789.272 Moya subsequently took the habit upon the death of three nuns. However, her profession was subsequently declared null and void and she was forced to leave the convent. ${ }^{273}$

María de la Encarnación Zequeira was even less fortunate. In 1788, on the heals of Moya's petition, María's father, Juan de Zequeira y Palma, petitioned for the Crown to admit his daughter as a protégé at santa clara. The petition included an allowance of a personal

271 AGI, SD 1142, Manuel Maria de Trujillo to the Council, September 1, 1788, attached to the August 7, 1788 expediente of Cecilia Josefa de Moya.

272 AGI, SD 1142, Consulta, December 10, 1788; AGI, SD 1473, Respuesta of the fiscal, september 1, 1788 .

273 AGI, SD 2241, Consulta, January 18, 1806. 
servant and the right to accede to the novitiate as a supernumerary nun at age sixteen, both of which were opposed by Trujillo. ${ }^{274}$ Concerned that in a little over two months Cecilia Josefa de Moya and María de la Encarnación Zequeira had petitioned the crown to be admitted as supernumerary nuns at Santa Clara, Trujillo took the same position he had with Moya, urging the Council to deny Zequeira's petition on the grounds that it would compromise the nuns' efforts to reduce their number to sixty-five and only worsen the "atraso exorbitante" of the community. On this occasion, the council sided with the commissary general, having determined that the aspirant's age and circumstances did not warrant an exception as they had in Moya's case. ${ }^{275}$

The Council did allow another Zequeira to enter Santa Clara a few months later. On July 2 of that same year, Rafaela de Zequeira y Palma, the daughter of the Conde de Lagunillas (Felipe José Antonio de Zequeira), entered the convent with the Council's approval. Subsequently, she

274 AGI, SD 1474, Juan de Zequeira Y Palma to the Crown (n.d.).

275 AGI, SD 1142, Consulta, March 30, 1789. 
was afforded the opportunity to take the habit at the first vacancy in the novitiate. However, in August of 1792 Bishop Felipe Josef Trespalacios y Verdeja reported that "ruined health" prevented the young woman from taking her vows and petitioned the crown to allow her to remain at the convent as a retiree, occupying one of the four cells set aside for women of that status. Rafeala de Zequeira's admission is indicative of the problems convents faced, as her presence at Santa Clara was only a result of her wanting to marry against her father's will. 276

Generally, however, Commissary General Trujillo was strong in his support of royal prerogative, voicing no philosophical objection to the admission of protégés. Under his watch, a number of young girls entered Santa Clara. Among them were María Ignacia Valdespino, Juana Gertrudis Perdomo, and Gertrudis de Zayas. Although the petitions of Valdespino, Perdomo, and Zayas bore resemblance to those of Cecilia Josefa de Moya and María

276 AGI, SD 1491, Felipe Josef Trespalacios y Verdeja to Pedro de Acuña, August 6, 1792; For the pressures that societal problems placed upon the male orders see Peire, "Estudio social y económico," 122. 
de la Encarnación Zequeira--in that all asked for the benefit of a personal servant and those of Valdespino and Zayas petitioned the right to accede to the novitiate-none of the three petitions included the right to profess as a supernumerary nun. More importantly, however, the petitions of Valdespino, Perdomo, and Zayas demonstrated the presence of kinship ties at the convent and/or poor prospects for a future outside the cloister. ${ }^{277}$ Maria Ignacia Valdespino had an aunt who was a professed nun at Santa Clara, Sister Lugarda Valdespino, who petitioned the Crown on her niece's behalf. ${ }^{278}$ Juana Gertrudis Perdomo did not have a relative at Santa Clara, but dire circumstances won her the commissary general's sympathy. Juana's father was deceased and her mother destitute ("sumamente pobre" in her words). She had entered Santa

277 AGI, Ultramar 365, Manuel Maria de Trujillo to the Council of the Indies, March 7, 1790; AGI, SD 1143, Consulta, July 15, 1790; AGI, SD 2241, Juana Gertrudis Perdomo to the Crown, May 4, 1791; AGI, SD 1143, Consulta, October 8, 1791; AGI, SD 1483, Antonio de Zayas-Bazán to the Crown, Eebruary 7, 1792.

278 AGI, Ultramar 365, Manuel Maria de Trujillo to the Council of the Indies, March 7, 1790; SD 1143, Consulta, July 15, 1790, and an attached respuesta of the fiscal dated May 12, 1790. 
Clara as a servant, lacking the dowry to become a nun. ${ }^{279}$ For many young women, like Juana Perdomo, the cloister was a refuge, an escape from poverty or, perhaps, sexual harassment. It was a source of shelter, food, and security. ${ }^{280}$ Fearing that she would be turned out of the convent by Trujillo's initiative to replace servants with lay sisters, Perdomo sought refuge in the non-servant secular class. ${ }^{281}$ Gertrudis de Zayas benefited from having kinship ties at the convent and bleak prospects for an education in the secular world. Gertrudis had an aunt who was a professed nun at Santa Clara. She also was one of five daughters of Antonio de Zayas-Bazán, who lamented in his petition to the crown that he could not educate the five "with the decency corresponding to their illustrious birth." 282

\footnotetext{
279 AGI, SD 2241, Juana Gertrudis Perdomo to the Crown, May 4, 1791; AGI, SD 1143, Consulta, October 8, 1791.
}

280 Martin, Daughters, 199.

281 AGI, SD 2241, Juana Gertrudis Perdomo to the Crown, MaY 4, 1791; AGI, SD 1143, Consulta, October 8, 1791.

282 AGI, SD 1483, Antonio de Zayas-Bazán to the Crown, Eebruary 7, 1792 . 
The Council took a very active role in two of the aforementioned cases. While Valdespino solicited admission to Santa Clara with the expressed intention of becoming a nun, Perdomo apparently had no intention of becoming a nun. She wanted to remain at the convent as a retiree. Nonetheless, the Council recommended she enter as a protégé. ${ }^{283}$ Trujillo actually deferred a decision on Gertrudis de Zayas' petition because the age of the aspirant was not included in the petition. The commissary general could concede a license to Gertrudis only if the girl had reached age seven. Otherwise, the papal nuncio had to grant the license. With a license of the commissary general, Gertrudis de zayas could remain at the convent until age twelve, at which time she had to petition the provincial in Havana. With the provincial's approval, she could remain at the convent until age sixteen, at which time she was expected to accede to the novitiate. The Council conditionally approved the

283 AGI, Ultramar 365, Manuel María de Trujillo to the Council of the Indies, March 7, 1790; AGI, SD 1143, Consulta, October 8, 1791. 
petition of Zayas, pending verification of her age. ${ }^{284}$ Although the aforementioned cases included a few complications, they demonstrate that the commissary general was not opposed to the admission of protégés or retirees. He insisted only that the three aspirants forgo the benefit of personal servants and that Valdespino and Zayas accede to the novitiate only when a vacancy occurred. 285

By 1794, however, Trujillo was gone from the scene, and in his place was Commissary General Juan de Troya, a prelate who placed ecclesiastical law above royal law in the jurisdictional hierarchy. Troya's refusal to concede a license to María Rafaela Garrido y Cabello forced the Council to reconsider the issue of whether ecclesiastical law took precedent in the admission of secular females at American convents. Resolving the issue took on an added sense of urgency with the arrival of new petitions in Madrid. On January 30, 1794 Francisco Ximénez Sarmiento

284 AGI, SD 1483, Manuel María de Trujillo to the Council, May 31, 1792, attached to Antonio de ZayasBazan's Eebruary 7, 1792 letter to the Crown.

285 Ibid. AGI, Ultramar 365, Manuel María de Trujillo to the Council of the Indies, March 7, 1790. 
appealed to the Crown to reconsider its refusal to admit María Rafaela Garrido y Cabello as a protégé at Santa Clara. In the appeal, Ximénez cited concessions made to Juana Gertrudis Perdomo and to "the two daughters of don Antonio Trevejo."286 Shortly thereafter, the Crown received a petition from Josef Fernández, who, on behalf of the widowed Condesa de Casa-Barreto, asked that the condesa's eight-year-old daughter, María de la Concepción Barreto, be admitted as a protégé at Santa Clara. ${ }^{287}$ María de la Concepción Barreto was the type of aspirant the Crown sought most to appease. The young girl not only had kinship ties at Santa Clara (two aunts who were professed nuns at the convent) but kinship ties on the highest rungs of elite society. Her father, the deceased Conde de Casa-Barreto (Jacinto Tomás Barreto y Pedroso), had been a prominent hacendado (planter) and member of the Havana cabildo, serving as the alcalde ordinario, regidor perpetuo (hereditary alderman), and

286 AGI, Ultramar 365, Francisco Ximénez Sarmiento to the Crown, January 30, 1794.

287 AGI, Ultramar 365, Josef Fernández to the Crown (on behalf of the widowed Condesa de Casa-Barreto) to the Crown, April 2, 1794. 
alcalde mayor provincial de la Hermandad (justice of the rural district around Havana). He also had been a teniente in the militia. ${ }^{288}$ A stepsister of Maria's (a daughter from the conde's previous marriage) had married Mateo Pedroso, the richest merchant in Havana and a regidor perpetuo on the cabildo, who also happened to be the Conde's first cousin. Maria's mother, the widowed Condesa de Casa-Barreto, was the daughter of Sebastián Peñalver, who had served on the cabildo with the Conde. Maria's uncle on her mother's side was the Marqués de Casa Peñalver (Gabriel Peñalver), the titular head of the Peñalver clan and a prominent hacendado who claimed the famous ingenio of Jesús Maria $y$ José among his holdings. ${ }^{289}$ Finally, a brother of Maria's was the Conde de Mopox. ${ }^{290}$ On May 10, 1794 the Crown instructed its Council to consult on how to best serve the needs of well-connected

288 Nieto, Dignidades, 107-110; Leví Marrero, Economía y sociedad, 13: 41 .

289 Peñalver had served twenty years as regidor (alderman) when he collaborated with the Earl of Albemarle during the British invasion in 1762 . He subsequently was tried and convicted of treason and died in disgrace in Ceuta (Thomas, Cuba, 44-45).

290 AGI, SD 2241, Consulta, January 18, 1806. 
individuals, like the widowed Condesa de Casa-Barreto, who frequently petitioned Madrid to have their daughters admitted as protégés at Santa Clara. The Crown proposed two possible solutions: the first was to secure a papal brief dispensing with all restrictions on the admission of young girls at Santa Clara and at the other two convents of the city, Santa Catalina and Santa Teresa; the second, should the first prove impractical, was to establish a secular colegio or an Ursuline convent ("a exemplo de Nueva Orleans") dedicated to the education of females. ${ }^{291}$ While deliberating the matter, the Council received yet another petition for a young girl to enter Santa Clara as a protégé. On July 24, 1794 a petition arrived from Manuel Juaquín Ramirez, a lawyer of the audiencias of Mexico and Santo Domingo, asking that his daughter Jacoba be admitted at the convent. Jacoba was fortunate to have relatives at the convent: two aunts and a great aunt who were professed nuns. The elder Ramirez asked that his

291 AGI, Ultramar 365, Royal Order, May 14, 1794. 
daughter be afforded the benefit of a personal servant and be allowed to accede to the novitiate at age sixteen. ${ }^{292}$ On August 12, 1794 the fiscal of the Council offered his solution to the Crown's dilemma. As a short-term solution, the official suggested that young girls continue to be admitted as protégés at Santa Clara. Like his predecessor in 1777, the fiscal argued that the authority to control admissions at the convent was entailed in the patronato and saw no need to recur to Rome for a papal brief or bull. He also supported the idea of extending the practice to Santa Catalina but cautioned against introducing protégés at Santa Teresa because of the austere lifestyle and rigorous daily routine of the Carmelite community. ${ }^{293}$

Life was indeed austere and the daily routine rigorous at the Carmelite community. The nuns rose each morning at four a.m. to begin a long day of prayer that did not end until nine or ten o'clock at night with the

292 AGI, Ultramar 365, Manuel Juaquin Ramirez to the Crown, March 10, 1794, attached to a Royal Order of July 29, 1794. 12, 1794 .

293 AGI, Ultramar 365, Respuesta of the fiscal, August 
recitation of matins (maytines). The rigorous routine left the nuns with little energy to expend on the education of young girls. Year-round abstinence from meat and seven months of fasting contributed to the nun's fatigue as well. While sick nuns ate guisado de carne (meat stew), which tended to be made with fowl, the rest of the community subsisted on guisado de abstinencia (abstinence stew). With so little time and energy, the nuns of Santa Teresa contracted out most sewing and embroidery and lay sisters did most of the cooking at the convent, meaning they rarely honed their skills in three areas that were considered essentials of a well-rounded female education in the late eighteenth century. ${ }^{294}$

As a long-range solution, he judged an Ursuline convent more feasible than a secular colegio but acknowledged that the establishment of either was subject to various bureaucratic delays. Such an endeavor would require that the Crown solicit reports from the governor and the bishop to determine the need for either an

294 AGI, SD 1491, The superiors of Santa Teresa to Felipe Joseph de Trespalacios y Verdeja, May 30, 1796, copied in the Testimonio of Francisco Fonte, June 28, 1796,11 . 
Ursuline convent or a secular colegio. The cabildo and the procurador sindico general would have to hold hearings on the matter. City officials would have to locate an appropriate site in the city, a difficult task in a walled city with a growing population, have plans drawn up by an architect or engineer, have the cost of the project calculated, and find funding for it. ${ }^{295}$ with regard to the petitions pending, the fiscal recommended approving those of the widowed Condesa de Casa-Barreto and Manuel Juaquin Ramirez but withheld judgment on Rafaela Maria Garrido $y$ Cabello's appeal until more information could be gathered on her social status and education to date. ${ }^{296}$

The Council, however, was concerned over the most restrictive of Benedict XIV's bulls: that of January 24, 1747. This bull appears to have incorporated all previous decrees restricting the admission of secular females at convents: it prohibited the admission of all secular females, regardless of whether they were retirees, servants or protégés, without papal license and just

295 Ibid.

296 AGI, Ultramar 365, Respuesta of the fiscal, August 12,1794 . 
cause, which could be determined only by a bishop or archbishop, not by a regular superior. In light of these prohibitive measures, the Council, in a consulta of November 6, 1794, recommended that the continued involvement of the crown in overseeing the admission of protégés at Santa Clara be contingent upon the receipt of a brief or bull dispensing with all ecclesiastical restrictions on their admission. It deferred a decision on the petitions of the Condesa de Casa-Barreto and Manuel Juaquin Ramirez until that dispensation could be acquired. ${ }^{297}$ With regard to Rafaela María Garrido $y$ Cabello's appeal, the Council agreed with the fiscal that the fate of the young girl should rest upon the review of additional information concerning her social status and education. ${ }^{298}$

297 AGI, SD 1144, Consulta, November 6, 1794; María de la Concepción Barreto eventually was admitted to the convent with a license of the bishop. On April 9, 1803, Maria's brother, the Conde de Mopox, petitioned the Crown to allow his sister to become a novice at the first vacancy in the novitiate. The Crown approved the Conde's petition three years later on May 13, 1806 (AGI, SD 2241, Consulta, January 18, 1806).

298 AGI, Ultramar 365, Acuerdo of the Council of the Indies, August 30, 1794, written at the end of the August 12. 1794 respuesta of the fiscal. 
Also in the consulta of November 6,1794 , the Council reiterated the fiscal's reservations concerning the introduction of protégés at Santa Teresa. However, when the Council drew up the instructions directing the Crown's minister in Rome to solicit a papal brief opening the doors of American convents to the education of young girls, it did not exempt the Carmelite community, or any other female community for that matter. Dated January 26 , 1795, the instructions directed the minister to solicit a brief abolishing all restrictions on the admissions of protégés "in the convent of Santa clara and the rest [of the convents] in the kingdoms of the Indies."299

Joseph Nicolás de Araña, the minister responsible for soliciting the brief, failed in three separate papal audiences to secure the sought after dispensation. In a letter dated June 24, 1795, Araña apologized to the Council for failing to bring to fruition "an idea so plausible like that of public education which contributes much to the general and particular good." In light of his failure, the minister suggested that the Crown circumvent

299 AGI, Ultramar 365, Instrucción to Ramón de Posada, January 6, 1796. 
Rome and simply order bishops, archbishops, and regular prelates to admit young girls at American convents. Araña, like the fiscal of the Council, believed that such authority was entailed in the patronato. As long as the families of the young girls paid the costs of room and board and covered other expenses, he saw no need to recur to Rome for a papal brief. ${ }^{300}$ Nonetheless, Araña continued in his quest to acquire a papal brief. In a fourth audience with the pope, the royal minister finally achieved his objective when the pontiff relented, agreeing to issue a brief dispensing with ecclesiastical restrictions on the admission of young girls to American convents. On July 22, almost a month to the day that Araña sent his first letter to the council, the minister sent another. To this one the minister attached the sought-after brief, which was dated the previous day, July 21. 1795.301

300 AGI, Ultramar 365, Joseph Nicolás de Araña to the Council of the Indies, June 24, 1795.

301 AGI, Ultramar 365, Joseph Nicolás de Araña to the Council of the Indies, July 22, 1795. 
The papal brief of JuIy 21, 1795 dispensed with the need to recur to Rome to admit a young girl to an American convent. Although leaving in place the restriction on the authority of regular superiors to concede licenses, the decree enhanced the authority of bishops and archbishops to act in this regard. Previously, ordinary prelates could only determine just cause, which would warrant the issuance of a papal license. The brief gave bishops and archbishops the authority to actually concede licenses for young girls to enter American convents. ${ }^{302}$

The brief also established new regulations governing the admission, matriculation, and behavior of young girls who entered convents. It allowed a girl to enter a convent at age seven but did not obligate her to accede to the novitiate, making her more a pupil than a protégé. Traditionally, pupils spent six or seven years in a convent, although some remained there indefinitely. Protégés sometimes spent a decade in preparation for the novitiate. The brief allowed a girl to enter a convent at age seven and remain there until she took the habit, chose

302 AGI, Ultramar 365, Translation of the papal brief of July 21, 1795, by Eelipe de Lamaniego, dated August 31, 1795. 
to marry, or reached age twenty-five. ${ }^{303}$ It also required that a young girl, whether she be a pupil or a protégé, forgo the benefit of a personal servant, dress moderately (e.g., not wear gold jewelry nor silk), sleep separately from the nuns, observe the rules of the cloister, and contribute the costs of her room and board. ${ }^{304}$ Thus, in many ways, the brief simply reinforced tradition. Customarily, girls living in convents were expected to observe the rules of the cloister, which may have included any of the following practices: dressing like nuns; following strict schedules of work, study, and prayer; eating meals in silence; and abiding by the rules of enclosure. ${ }^{305}$ It should be noted, however, that young girls frequently lived in the cell of a relative. So common was this practice that Commissary General Manuel de

303 AGI, Ultramar 365, Translation of the papal brief of July 21, 1795, by Eelipe de Lamaniego, dated August 31, 1795; In Spanish culture a woman was subject to her father's will until age twenty-five; if unmarried at age twenty-five, a woman gained her independence from her father (Martín, Daughters, 78; Lavrin, "Colonial Woman in Mexico," 30).

304 AGI, Ultramar 365, Translation of the papal brief of July 21, 1795, by Felipe de Lamaniego, dated August 31, 1795.

$$
305 \text { Martin, Daughters, } 78 .
$$


la Vega, in approving the admission of Maria Ignacia Valdespino, simply assumed that the young girl would live in the cell of her aunt, Sister Lugarda Valdespino. ${ }^{306}$

A cédula of December 26, 1795 ordered bishops and archbishops in the Americas to implement the papal brief. In May of 1796, Bishop Felipe Josef de Trespalacios y Verdejas, received copies of the cédula and the brief from the governor and immediately brought them to the attention of the superiors of Santa Clara, Santa Teresa, and Santa Catalina. The bishop hoped that the superiors would convene their communities to determine the number of protégés each convent could accept and the amount in annual room and board that would be required of each. ${ }^{307}$ However, a clause in the brief allowed the communities to reject the measure outright, which each did in turn.

306 AGI, Ultramar 365, Manuel Maria de Trujillo to the Council of the Indies, March 7, 1790.

307 AGI, SD 1491, Auto of Eelipe Josef de Trespalacios $y$ Verdeja, May 18, 1796, copied in the testimonio of Francisco Fonte, June 28, 1796; Martin says in seventeenth-century Peru, the universal custom was to collect fifty pesos per student "por solo pisar el suelo del monasterio" (just to walk on the ground of the nunneryl. An additional 100 to 200 pesos were expected each year to cover room and board, clothing, and medical care (Martin, Daughters, 77). 
The superiors of Santa Clara reported on May 27 that their community could not abide by the measure, particularly because it called for the young girls to live separately from the nuns and to enter without the benefit of personal servants. Renowned for its overcrowding, Santa Clara had recently become more crowded with the addition of the Santo Domingo Clares (1795). Thus, in January of 1796, there were 106 nuns living at the Observant Franciscan community in Havana: eighty-two who were original to the Cuban community and twenty-four immigrant nuns from Santo Domingo. Whereas some in the Cuban community lived two to a cell, the immigrant nuns lived four or five to a cell. Also by 1796, many at Santa Clara had embraced communal life, meaning that a majority of the nuns were dependent upon a few communal servants. The admission of pupils was sure to worsen overcrowded conditions and overburden communal servants, shifting additional tasks to the nuns themselves. Neither of the prospects appealed to the sisters, who believed that the fathers of the girls were responsible for their daughters' education. ${ }^{308}$

308 AGI, SD 1491, the superiors of Santa Clara (Madre de San Josef (abbess), Margarita de la Presentación (madre 
Conditions at Santa Catalina and Santa Teresa were no more conducive to the admission of large numbers of young girls. The situation at Santa Catalina was similar to that at Santa clara in that the Dominican community had witnessed a population increase as a result of the Treaty of Basle. As a percentage of total population, the increase at Santa Catalina actualiy was much greater than that at Santa clara. The arrival of twenty-seven Dominican nuns, with their servants, from Santo Domingo in December of 1795 more than doubled Santa Catalina's population: the Dominican community of Havana was comprised of only twenty-five nuns and did not employ personal servants. At Santa Catalina the immigrant nuns were housed two or three to a cell. At Santa Teresa, the situation was somewhat different. The Carmelite community had not grown as a result of the Treaty of Basle. Its population still numbered no more than twenty-one nuns and

de consejo), Bárbara María de la Santa Corona (madre de Consejo), Bárbara María del Sacramento (madre de consejo), María Josefa de la Asumpción (vicaria de la casa), María de San Agustin (difinidora), Antonia de San Juaquín (difinidora), Clara Josefa de Santa María de la luz (difinidora) to Felipe Josef de Trespalacios y Verdeja, May 27, 1796, copied in the Testimonio of Erancisco Fonte, June 28, 1796, 7-9. 
three lay sisters. However, its members were forbidden to share cells, making it such that the Carmelite community simply lacked the space to abide by the measure. Santa Teresa's difficulties only were compounded by the austere Carmelite lifestyle and rigorous daily routine which, as noted above, left its members precious little time or energy to devote to the care and education of young girls. 309

Angel Huerta has found no evidence to suggest that Santa Catalina, Santa Teresa, or even Santa Clara accepted young girls in accordance with the cédula of December 26 , 1795. In the years following the issuance of the cedula Santa clara continued to accept only protégés (i.e., only those who aspired to become nuns). Huerta attributes the non-compliance to both the fallout from the Treaty of Basle and the migration of sixteen Ursuline nuns from New Orleans to Havana in June of $1803 .{ }^{310}$

309 AGI, SD 1491, the superiors of Santa Catalina to Felipe Josef de Trespalacios y Verdeja, June 25, 1796, copied in the Testimonio of Francisco Fonte, June 28, 1796, 13, and the superiors of Santa Teresa to Eelipe Josef de Trespalacios y Verdeja, May 30, 1796, copied in the Testimonio of Francisco Fonte, June 28, 1796, 10-13; Huerta, "El monacato femenino," 498-499.

310 Huerta, "El clero cubano," 553. 
The arrival of the Ursuline Order, which had gained a reputation in New Orleans as one of the premiere educating orders in the Spanish empire, not only marked the dawn of a new age in Cuban female education, but was a panacea in that it fulfilled both the Crown's desire to appease the elite of the city and warded off, at least temporarily, any need for the convents Santa Clara, Santa Catalina, and Santa Teresa to open their doors to pupils. The respite for the Eranciscans, Dominicans, and Carmelites lasted until January of 1819, when the three convents opened schools for poor girls, in accordance with a cédula of October $20,1817.311$

In summary, the cédula of December 26, 1795, which Asunción Lavrin argues "annulled" reforms designed to rid Mexican convents of secular females, had no measurable impact in Havana because the three female communities of the city never acted in accordance with the measure. ${ }^{312}$ Nonetheless, the cédula does demonstrate the lengths to which the Crown was willing to go to appease the Havana

\footnotetext{
311 Ibid., 490.

312 Lavrin, "Reform of Nunneries," 201.
} 
elite. This willingness to compromise in the area of conventual reform was in keeping with a pattern the crown exhibited in administrative, commercial, and military reforms on the island. Of utmost concern to the crown was the maintenance of empire. ${ }^{313}$

While the arrival of the Ursulines was certainly a panacea in the short run, it proved to be a curse in the long term. The fact that santa clara was no longer the only option for elite families desirous of an education for their daughters marginalized the community in the eyes of the Crown. While Santa Clara did not want pupils, and did not really need protégés, its lifeblood was novices. The migration of sixteen Ursulines from New Orleans and twenty-five Clares from Santo Domingo resulted in a moratorium on new novices, condemning Santa Clara to a precarious future.

313 For a discussion of flexibility in commercial reform see Kuethe and Inglis, "Absolutism and Enlightened Reform"; For discussion of compromise in military reform see Kuethe, Crown, Military, and Society. 
CHAPTER IX

THE MORATORIUM OF 1797

In 1797, with 106 nuns living at Santa Clara, the Crown made the difficult decision to declare a moratorium on the admission of new novices at the convent. In doing so, it solved one problem by arresting population growth at the convent but caused another by severing the community's lifeblood. Without the infusion of new novices, the community grew old and infirm. Although the official moratorium on novices did not take effect until January of 1797, no new novice entered Santa Clara between 1794 and the abdication of Charles IV in 1808, despite frequent appeals from abbesses of the convent. Although sympathetic to the community's plight, the crown refused to lift the ban on the admission of new novices, remaining committed to its goal of reducing Santa Clara's religious population. Relief would not come until three years after the abdication of Charles IV, when the Cortes gave Bishop Juan José Díaz Espada y Landa (1802-1832) permission to admit novices at Santa Clara. Even then, however, the permission came with the stipulation that the religious population of the convent was not to exceed sixty-five. 
The arrival of the twenty-five Clares from Santo Domingo in December of 1795 presented the Crown with a serious dilemma. Allowing the Cuban community to continue admitting one novice for every three nuns who died, a policy established in 1787 but one that was never officially sanctioned by the crown, would ensure its vibrancy but, at the same time, was sure to subject the convent's inhabitants, particularly the immigrant nuns from Santo Domingo, to tremendous hardship born out of overcrowded conditions. As noted in chapter eight, while some in the Cuban community lived two to a cell, the immigrant nuns lived four or five to a cell. Declaring a moratorium on the admission of new novices was sure to bring about a rapid reduction in the convent's religious population; but, at the same time, such a measure would condemn the community to a precarious future, one sure to be characterized by old age and infirmity. ${ }^{314}$ After deliberating on the consequences of both policies, the

314 Commissary General Pablo de Moya first raised the issue of whether a moratorium should be declared on the admission of new novices at Santa Clara in an August 20, 1796 letter to the Crown (AGI, Ultramar 396, Pablo de Moya to Francisco Cerdá, August 20, 1796). 
Council opted for the latter. ${ }^{315}$ In a consulta of December 22, 1796, the tribunal concluded that a moratorium should be placed on the admission of new novices until the crown determined what to do with the immigrant nuns. The consulta also recommended that the 1788 decision of the Cuban community to reduce its population to sixty-five be given royal sanction. The king concurred with the Council's recommendation. ${ }^{316}$

Although belated, the sanctioning of the eight-year old decision was pivotal in ensuring a continued reduction in the community's religious population, because royal sanction made the self-imposed reduction binding. Because the Crown had never sanctioned either the 1787 proposal of Commissary General María de Trujillo to limit Santa Clara's religious population to seventy or the 1788 decision of the nuns to limit their number to sixty-five, $10,1796$.

315 AGI, Ultramar 396, Reply of the fiscal, October

316 AGI, Ultramar 396, Consulta, December 22, 1796, and Council of the Indies to Pablo de Moya, February 13, 1797; AGI, SD 1497, Gertrudís del Corazón de Jesús Morodo (abbess of the Santo Domingo community) to Fernando Portillo y Torres (Archbishop of Santo Domingo), July 23, 1798, attached to the expediente of Gertrudis del Corazón de Jesús Morodo (\#21). 
the Cuban community could grow to ninety nuns without running afoul of royal law. Royal sanction insured against the possibility that the community would go back on its self-imposed pledge to reduce its number to sixtyfive. The Crown approved the consulta on January 31 , 1797.317

Three years after their migration to Havana, the twenty-two surviving members of the Santo Domingo community still were living as guests of the Cuban community. As unofficial guests, the immigrant nuns owed allegiance to a separate set of superiors and governing body and had no say in the administration of the convent. If incorporated, the immigrant nuns would acquire a voice in the administration of the convent, i.e. they would acquire voz activa and voz pasiva; however their incorporation also would give their presence at the convent an unwelcome sense of permanency. ${ }^{318}$

317 Ibid.

318 AGI, SD 1497, Gertrudis del Corazón de Jesús Morodo to Fernando Portillo y Torres, attached to the expediente of Gertrudis del Corazón de Jesús Morodo (\#21). 
By 1798 the Santo Domingo community had grown weary of its uncertain status. On July 23 of that year, its abbess, Gertrudis del Corazón de Jesús Morodo, wrote to the Archbishop of Santo Domingo, Eernando Portillo y Torres, in the hope that he might sway the crown and the commissary general to bring some closure to the triennium of uncertainty. Nearing the end of her term in office, Morodo asked that her community be incorporated fully into the Cuban community or officially declared guests of the latter and granted an income. ${ }^{319}$

Archbishop Portillo, Commissary General Moya, and the Council of the Indies all supported the full incorporation of Santo Domingo community. Portillo, the official who engineered the community's migration to Havana, believed that its members should be incorporated "...as if they had professed in [the Cuban community]." He deemed such action warranted, citing the fact that the community had deposited with the royal hacienda silver and gold alhajas (ornamentation) from their convent's church, totaling an arroba and a half (approximately thirty-seven and one-half pounds) and valued at 8,192 pesos. Subsequently, the

319 Ibid. 
royal hacienda lent the equivalent of their value, 8,192 pesos, to Cayetano Reyna, a teniente in the artillery, who invested the money in an ingenio. As was custom, Reyna pledged to pay annually an amount equal to five percent of the principal. By this means the Santo Domingo community was supposed to net 410 pesos annually. The archbishop also claimed that the sale of the community's convent had brought 20,000 pesos, money also reportedly deposited with the royal hacienda. However, there seems to be some discrepancy here. While the archbishop claimed the sale brought 20,000 pesos, which should have yielded the immigrant community a five percent return of 1,000 pesos annually, the Principe de la Paz reported that the selling price was a mere 1,000 pesos, which would have only yielded the nuns fifty pesos a year. The Junta de emigrados eventually settled the issue by assigning to each member of the Santo Domingo community a royal pension designed to ensure each nun an income of twenty-sevenpesos monthly, an amount equal to the mesada payments of the Cuban community in the late 1790s. ${ }^{320}$ Although

320 Huerta, "El monacato femenino," 503, 509; AGI, SD 1497, Fernando Portillo y Torres to the Crown, July 23, 1798, attached to the expediente of Gertrudis del Corazon 
concerned that neither the rents nor the physical capacity of Santa clara was adequate to support an additional twenty-two nuns and their servants, Commissary General Moya seemed satisfied by the aforementioned gestures of the Santo Domingo Community. Like Portillo, Moya supported a full incorporation of the immigrant nuns. However, unaware that a moratorium had been declared on admissions of new novices at Santa Clara, Moya asked that future novices should enter the convent only with his permission, a permission which he agreed to grant only upon verification that three nuns had died. 321 The Council agreed with Moya, insofar as the Santo Domingo community should be incorporated into its sister community but strongly opposed the admission of new novices until the number of nuns was reduced to sixty-five. ${ }^{322}$ A subsequent royal cédula of August 11, 1799 ordered the full

de Jesús Morodo (\#21); AGI, Ultramar 132, Principe de la Paz to the Captain-General of Cuba, September 28, 1796.

321 AGI, SD 1497, Pablo de Moya to Erancisco Cerdá, Eebruary 16, 1799, attached to the expediente of Gertrudis del Corazón de Jesús Morodo (\#21).

322 AGI, SD 1497, Reply of the fiscal, April 12, 1799, attached to the expediente of Gertrudis del Corazón de Jesús Morodo (\#21); AGI, SD 1146, Consulta, May 18, 1799. 
incorporation of the Santo Domingo community and, heeding the Council's caution, a continuation of the moratorium. ${ }^{323}$ Friction between the Cuban and Santo Domingo communities persisted down to 1817, when the latter finally received permission to return to its native island. Certainly, the moratorium on new admissions at the convent was a major source of contention. Also damaging relations between the two communities was the fact that the presence of the Santo Domingo nuns posed a serious financial burden for the clares of Havana, because the amount in royal pensiones actually paid by the hacienda did not support the assigned mesada of twentyseven pesos. However, the point became moot with the passage of time, because twenty-seven pesos proved to be inadequate for meeting the needs of the aging and increasingly infirm guests. ${ }^{324}$

323 AGI, SD 1497, Note of the Council of the Indies (n.d.), attached to the expediente of Gertrudis del Corazón de Jesús Morodo (\#21); AGI, SD 1146, Consulta, May $18,1799$.

324 In 1810 the abbess of the Cuban community called for the punctual payment of the pensiones and a return of the alhajas. A royal cédula of April 11, 1811 ordered the payment of the pensiones but denied the request to return the alhajas (Huerta, "EI monacato femenino," 503; AGI, Cuba 1693, Cédula, August 11, 1811; AGI, Ultramar 396, Silvestre Collar to Pablo de Moya, June 12, 1812). Six 
By the first years of the nineteenth century, old age, sickness, and handicaps had begun to take their toll on Santa Clara. The nuns no longer executed temporal and spiritual duties with the exactitude they once did. Among the temporal duties generally considered to require youthful vigor, strength, and agility were those associated with the sacristy, the infirmary, the granjeria, and the refectory. The proper execution of spiritual obligations also depended on harnessing youthful vigor and exuberance. With a coro deplete of nuns with good vision, clear voices and strong lungs, worship services lacked the grandeur of old. ${ }^{325}$

years later, in 1816, a subsequent abbess called, once again, for a return of the alhajas and, at the same time, complained that the pensiones paid by the royal hacienda were diminishing. She added that even if paid in full, twenty-seven pesos were no longer adequate to cover the rising costs associated with an aging and increasingly disabled community. She asked that the amount be increased from twenty-seven pesos to thirty-five pesos (Huerta, "El monacato femenino," 503; AGI, Ultramar 132, Note of the Ministry of Ultramar, (n.d.)); The immigrant nuns finally received royal permission to return to their native island, but not until september 4, 1817 (Huerta, "El monacato femenino," 503; AGI, Ultramar 3, Consulta, August 14, 1817; AGI, Ultramar 132, Royal Order, September $4,1817)$.

325 AGI, Ultramar 396, Pablo de Moya to Antonio Porcel, July 12, 1804, and Pablo de Moya to Antonio Porcel, November 10, 1807, a copy of which is attached to 
The weight of the crisis fell upon the shoulders of the abbess. It was the abbess, after all, who was responsible for filling all of the conventual offices from a shrinking pool of candidates. Her task was made more difficult by the restrictions associated with communal life and the moratorium: there were fewer servants at the convent, and the presence of the Santo Domingo community negated the introduction of lay sisters. ${ }^{326}$ Beginning in the late eighteenth century and increasingly in the early nineteenth, abbesses of Santa Clara frequently appealed to the commissariat to have the ban on the admission of new novices lifted. In 1804, after the "repeated clamoring" of an abbess, Commissary General Moya attempted to intercede on the community's behalf. On July 12 of that year, Moya asked the Crown to allow the Havana community

the March 9, 1815 letter of Pablo de Moya to Esteban Varea.

326 Ibid. The description of characteristics needed to fill the various positions of the convent are taken from AGI, Ultramar 396, Pablo de Moya to Silvestre Collar, March 21, 1812, a copy of which is attached March 9, 1815 letter of Pablo de Moya to Esteban Varea. For discussion of the abbess' control of patronage see Martin, Daughters, 261-266. 
to admit new novices, without specifying any particular number. ${ }^{327}$

The Council, although sympathetic to the nuns' plight, opposed lifting the ban on the admission of new novices. Citing the fact that the king still had not made a decision on the fates of the immigrant nuns from Santo Domingo, the fiscal of the Council determined that the moratorium should remain in place so long as the religious population of the convent exceeded sixty-five. ${ }^{328}$ In actuality, it was relatively easy in 1804 to turn a deaf ear to the clamoring of the abbess, because the arrival of sixteen Ursulines from New orleans the previous year had relieved pressure on the Crown to admit the daughters of Havana's elite to Santa Clara. ${ }^{329}$ As mentioned earlier,

327 AGI, Ultramar 396, Pablo de Moya to Antonio Porcel, July 12, 1804, and Pablo de Moya to Antonio Porcel, November 10, 1807 (a copy of the latter is attached to the March 9, 1815 letter of Pablo de Moya to Esteban Varea).

328 AGI, Ultramar 396, Reply of the fiscal, September 25, 1804, and Pablo de Moya to Antonio Porcel, November 10, 1807 (a copy of the latter is attached to the March 9, 1815 letter of Pablo de Moya to Esteban Varea).

329 The superior of the Ursulines actually had petitioned the Crown to transfer either to Havana or Mexico City. The Council of the Indies opted for the former (Huerta, "El clero cubano," 540). 
the arrival of the Ursuline Order was a panacea, fulfilling the Crown's desire to appease the elite of the city without necessitating a compromise in the stringency of the measures implemented to reduce Santa Clara's religious population. No action was ever taken in response to the commissary general's 1804 petition.

Without the infusion of new novices, conditions at Santa Clara rapidly deteriorated. By 1807 Santa Clara had endured nearly forty years of continuous reform, dating back to 1768 , during which the community's right to admit novices either had been severely restricted or prohibited. On August 8 of that year, the abbess of Santa Clara dispensed with protocol and appealed directly to the crown for relief, asking that the maximum allowable number of nuns be raised from sixty-five to seventy. ${ }^{330}$

Commissary General Moya was not disturbed by the abbess' action. When made aware of the nun's petition, Moya expressed his support for it, citing the dire social consequences the moratorium had caused and also the new

330 AGI, Ultramar 396, Pablo de Moya to Antonio Porcel, November 10, 1807, a copy of which is attached to the March 9, 1815 letter of Pablo de Moya to Esteban Varea; Huerta "El monacato femenino," 501. 
found fiscal solvency of the community. The commissary general painted a grim picture of life at the convent, saying that a majority of the nuns were over age sixty, a dozen past seventy, and one over 100. Adding that four nuns were crippled, one was blind, and almost all were afflicted by some infirmity or another, he concluded that "hardly one could be declared healthy."331 However, Moya painted a rosy economic picture. Although he did not have in-depth knowledge concerning the status of the convent's rents--keeping track of such information was the responsibility of the provincial--he surmised that rents were in "good order." His reason for such an appraisal? The community recently had made repairs to the convent and had added "nine or ten" cells, with more under construction. This and the fact that the community had contributed 7,272 pesos to "urgencias" of the crown in August of 1805 led the commissary general to declare the convent solvent. Moya attributed the solvency to the "good management of the last two or three abbesses... and the zeal of [the] provincial."332

332 Ibid. 
The solvency may have owed as much to the onset of the sugar boom as to efficient management. The sugar industry experienced tremendous growth after 1790, owing initially to the Haitian Revolution and subsequently to the elimination of trade barriers, the unlimited importation of slaves, and flourishing trade with the United States. ${ }^{333}$ The Haitian Revolution destroyed plantations and chased planters from that island. Many of these individuals arrived in Cuba with capital, slaves, and know-how. ${ }^{334}$ Between 1790 and 1807, sugar exports rose from 15,423 tons to 41, 165 tons. ${ }^{335}$ Between 1792 and 1806, the number of mills around Havana rose from 237 to $416 .{ }^{336}$ Although the immediate impact of the sugar boom on Santa Clara is not known, the convent did come to own twenty plantations in the nineteenth century. One can only

333 Jaime Suchlicki, Cuba: From Columbus to Castro (New York: Charles Scribner's Sons, 1974), 51; Pérez, Between Reform and Revolution, 72.

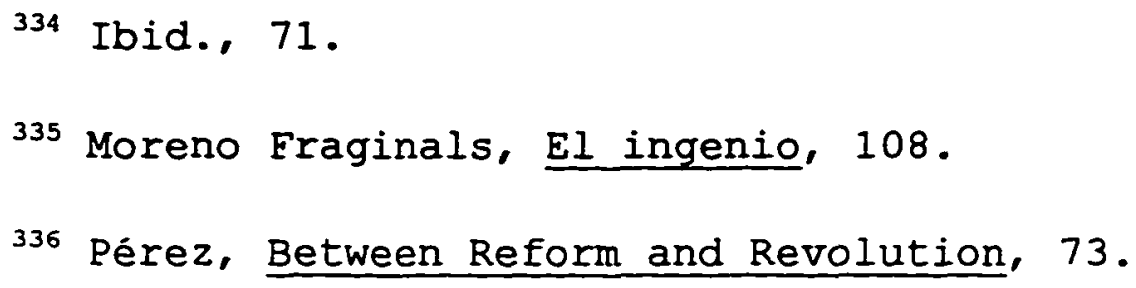


assume that the convent's fortunes soared with those of other religious houses. ${ }^{337}$

Moya's 1807 letter, which included a petition to admit "ten or twelve" novices immediately and thereafter an additional novice only in the case that one of these new entrants died, never received a hearing in the Council's chambers. ${ }^{338}$ When the Erench forced the abdication of Charles IV in 1808, and immediately thereafter that of his son, Ferdinand VII, the Spanish empire was left without a sitting monarch, and the work of the Council was interrupted. ${ }^{339}$ However, royal regulations that had restricted the admission of novices at santa Clara for four decades, and had not allowed a single novice to enter during the previous fourteen years,

337 Thomas, Cuba, 82; For discussion of soaring fortunes see Maza, "True struggles and False Dilemmas," and Kirk, "Between God and Party."

338 AGI, Ultramar 396, Pablo de Moya to Antonio Porcel, November 10, 1807, a copy of which is attached to the March 9, 1815 letter of Pablo de Moya to Esteban Varea.

339 Clarence Haring, The Spanish Empire in America (New York: Oxford University, 1947; San Diego: Harcourt Brace Jovanovich, 1985), 108 (page citation is to the reprint edition). 
continued in effect, even in the absence of a monarch. In 1811 the Cortes of Cadiz finally relented, allowing santa Clara's population to grow to seventy. At the time, there were sixty-six nuns living at santa clara, fifty-one of whom were original to the Cuban community (see Appendix C). The Santo Domingo community, which would never be fully incorporated into its sister community, continued to be counted separately even at this late date. Its number had dwindled to fifteen by 1811. The Cortes' resolution permitted the community to admit four novices, but with the stipulation that it be done at the discretion of the bishop. 340

By 1811, however, it already was apparent that santa Clara would never recapture its past glory. The Observant Eranciscan community simply was out of step with the times. No longer did it sit atop the pinnacle of Havana society. Rather, it had been relegated to the periphery. In the secular enlightened age of the nineteenth century, educating orders, like the Ursuline Order, had come to

340 AGI, Ultramar 396, Royal Order, June 8, 1813, summarized in the expediente of the Council of the Indies, 1813; AGI, SD 1306, Estado que comprende los bienes que poseen en esta Isla los conventos de regulares de ambos sexos que en ella existen, 1837 . 
garner the prestige once reserved for orders that populated the conventos grandes of the empire. 
CHAPTER $\mathrm{X}$

CONCLUSION

Asunción Lavrin argues that the reform of Mexican convents in late eighteenth-century was largely ineffective. ${ }^{341}$ I suggest that its counterpart at santa Clara achieved much better results. While the reform of the Observant Franciscan community did not attain perfection, it followed the pattern of administrative, economic, and military reform in that it was more effective on the island than it was elsewhere in the Spanish empire.

The success of conventual reform in Havana must be attributed to the diligence of the Spanish Crown. Whereas the reform of convents in Mexico became a local concern after 1780, its counterpart at Santa Clara garnered the attention of Spanish officials in Madrid down to the abdication of Charles IV in 1808, and beyond. ${ }^{342}$ It must be recognized, however, that effective reform did not always equate to beneficial reform. The same reforms that

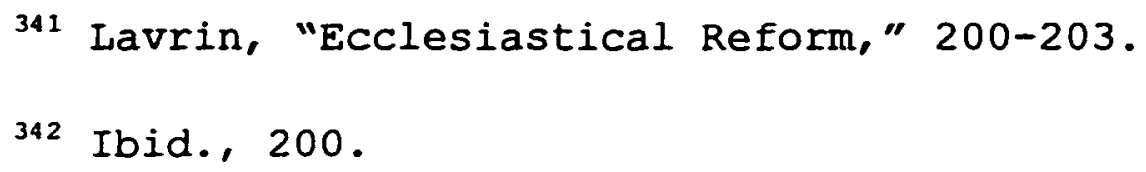


reduced the number of religious and secular females Iiving at Santa Clara and reestablished communal life at the convent also divided the community and robbed it of its vibrancy.

Santa Clara was an obvious target for reform in the 1760s. Not only the largest, wealthiest, and most prestigious female community in Havana, Santa Clara was also the least disciplined. On the eve of the reform in 1768, there were approximately 112 nuns, each of whom had a personal servant or two, and upwards of forty protégés and retirees living at Santa Clara, many of whom had personal servants as well. The convent's total population probably exceeded 300 .

Reformers moved cautiously against Santa Clara, aware of elite influence at the convent. The observant Franciscan community had long been a bastion of the socioeconomic and ethnic elite of Havana. Leading families of the city deposited their daughters at santa clara and treated the affairs of the convent as their own. Their daughters, although cloistered, maintained a comfortable lifestyle, living in well-furnished cells and being waited on by personal servants. In such an atmosphere there was very little incentive to reform, and the Crown had to 
adopt a carrot and stick approach. Whenever the nuns and their families were negatively affected by reform legislation, the Crown would offer some concession.

In 1768 the main goals of the reform were to reduce the number of nuns living at Santa clara from approximately 112 to ninety and the number of retirees and protégés from more than forty to fifteen, while stripping both groups of their personal servants. That it took fifteen years, or until 1783, to realize, or even to begin to realize, these goals is a testament to the will and influence of Havana's elite.

Opposition on the part of the nuns and their powerful families not only interfered with efforts to reduce santa Clara's religious, secular, and servant populations but worked to water down other reforms and make them more palatable. When communal life was reestablished at the convent in 1783 it was not binding. Rather, the nuns were given the option of adopting communal life or continuing in the private regimen to which they had become accustomed. By choosing to continue in private life, they could retain their comfortable lifestyles but had to forfeit the right to vote in communal elections or to hold office. Long accustomed to their personal resources and 
personal servants, the nuns overwhelmingly rejected communal life. More than three-quarters of the community, seventy-one of the eighty-four professed nuns, opted to continue in the private regimen. The six novices living at Santa Clara were compelled to embrace communal life.

The re-establishment of communal life and the restrictions on suffrage and holding office fractured the close-knit community along socio-economic and familial lines. No daughter of a noble family appears among the thirteen names of those who voluntarily embraced communal Iife, and only two officers do, the vicaria de la casa and the maestra de novicias. Only among the novices, who were compelled to adopt the regimen, does the name of the daughter of a nobleman appear. The daughters of the leading families of Havana, as well as the great majority of the convent's highest officers were concentrated among the ranks of those in private life. The mature and merited nuns, whose pedigrees and experience qualified them to hold high office at the convent, were precluded from political participation. Iingering discord and division eventually led to calls for the restoration of suffrage and office-holding rights to those in private life. 
The Crown understood that the discord and division afflicting Santa Clara were unavoidable consequences of the decision to allow the nuns to choose their own fates; but it also recognized that such problems were only transitory. By requiring that all new novices swear themselves to a lifetime of communal living, the crown ensured that with the passing of a generation or two, the convent would be reformed. However, reform was far simpler on paper than it was in practice.

Within a half-decade of the re-establishment of communal life, fiscal shortfalls led to calls for a more drastic reduction in Santa Clara's religious population,. In 1788 the nuns took the initiative by calling for a reduction in their number to sixty-five, a population that was more in line with what communal resources could support and also one that exactly matched the number of cells at the convent. A policy was established to admit one novice for every three nuns who died in order to effect a gradual population reduction.

The effort appears to have been successful, if only temporarily so. By the summer of 1795, the religious population of the Cuban community had been reduced to eighty-two, and about half of those lived in communal 
life. However, Santa Clara's total religious population stood at 106, only six fewer than had lived at the convent prior to 1768, and at least twenty-five servants had been added to the mix.

Two of the basic gains of the reform, the reductions achieved in Santa Clara's religious and servant populations, had fallen victim to international politics. When Spain ceded Santo Domingo to France in the Treaty of Basle (1795), the twenty-five Clares of the island were forced to migrate to their sister community in Havana. ${ }^{343}$ with no alternative, the crown declared a moratorium on the admission of new novices at Santa Clara in 1797, thereby dooming the community to a precarious future.

A royal cédula of December 26, 1795 threatened to annul another gain of the reform: the reduction achieved in Santa Clara's secular population. This decree, which opened the doors of American convents to the education of young girls, threatened to turn Santa Clara into a defacto colegio. Traditionally, Santa Clara had admitted protégés but had never admitted pupils. of Mexico, Asunción Lavrin

\footnotetext{
343 In 1796 this number included eighty-two nuns who were original to the Cuban community and twenty-four nuns from Santo Domingo.
} 
says: "with this cédula one of the basic points of the reform was annulled. ${ }^{344}$ However, the cédula had no effect in Havana, the city for which it was actually written, because neither Santa Clara nor the other two convents of the city ever acted in accordance with the decree. Fortunately, they never had to. In the first decade of the nineteenth century, international politics worked to their favor. When Spain ceded Louisiana to France in 1802, sixteen Ursuline nuns migrated from New Orleans to Havana, founding a convent in 1804 and dedicating themselves to the education of young girls.

In time, conventual reform in Havana--whether undertaken as a result of the crown's initiative or of the community's own initiative--proved effective. Within a half-decade of the abdication of Charles IV in 1808, the goal of reducing Santa Clara's religious population to sixty-five was all but achieved. In 1811 there were sixty-six nuns living at the convent, and only fifty-one of these were original to the Cuban community. Of these fifty-one, thirty-seven (seventy-five percent) observed communal life, which means that only fourteen nuns

344 Lavrin, "Ecclesiastical Reform," 201. 
retained the right to hold personal servants. The combined number of retirees and protégés at the convent had been reduced from approximately forty to fifteen or fewer, and it can be assumed that very few, if any, of these held personal servants. 345

In conclusion, the primary goal of the reform, to force all of the nuns at Santa clara to live communally, was nearing fulfillment. Other goals--such as those to make the nuns live according to their Rules and Constitutions in spiritual and temporal matters, to curb excessive expenditures, and to reduce the religious population of the convent to ninety--had been fulfilled or surpassed. However, the same reforms that ended Santa Clara's reliance on private resources and blocked the admission of novices robbed the Observant Franciscan community of its vibrancy. By the time Charles IV abdicated, a once proud and vibrant community was humbled, aged, and infirm. Marginalized in the eyes of the crown and the Havana elite, Santa Clara was defenseless in an increasingly secular, often anticlerical, age.

345 This assumes that the moratorium on new novices and the arrival of the Ursulines made it far less attractive to become a protégé at Santa Clara. 


\section{EPILOGUE}

The admission of four novices in 1812 marked the end of the moratorium, but it was by no means a panacea to all that was ailing Santa Clara. The Observant Eranciscan community was out of step with the times. In the secular, enlightened age of the nineteenth century, the Ursulines eclipsed the prestige of the Observant Franciscans. As early as 1809, there were fifty girls boarding at the Ursuline convent, either as pupils or protégés, and another 136 attending on a daily basis. By 1813 fortyfive girls were boarding at the convent and 146 were attending daily. ${ }^{346}$ The Observant Franciscans did eventually get into the business of educating pupils, opening a school in 1819 dedicated to the education of poor girls. ${ }^{347}$ However, they simply were not the equals of the Ursulines in the area of female education. The numerical growth of the Ursuline community and the corresponding decline of the Observant Eranciscan community are telling signs. A census taken in

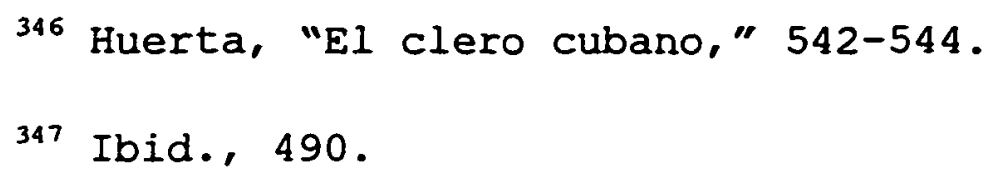


conjunction with the suppression of all religious orders in 1837 recorded twenty-nine professed nuns and one novice were living at the Ursuline convent, even though four Ursulines had migrated to Puerto Principe to found a sister community, which itself had grown to include sixteen professed nuns. By contrast, the same census recorded only thirty-nine professed nuns, and not a single novice, living at Santa Clara, this despite the fact that two decades had passed since the Santo Domingo community received permission to return to its native island (see Appendix B) ${ }^{348}$ Certainly there were factors other than the coming of the Ursulines which contributed to santa Clara's waning prestige and diminishing numbers, however the Observant Franciscan community's inability to keep pace in an age of shifting attitudes seemed to be at the root of its afflictions.

Was Santa Clara reformed when all religious communities were suppressed in 1837? One can assume that the ranks of those living in private life were all but

348 Huerta, "El monacato femenino," 504, 506; Huerta, "El clero cubano," 543; AGI, Ultramar 396, Royal Order, June 8,1813 , summarized in the expediente of the Council of the Indies, 1813. 
depleted, if not entirely depleted, by that late date. No novice had entered the convent in the custom of private life since the mid-1770s, and only fourteen nuns clung to the regimen as of 1811. Eurthermore, a reluctance on the Crown's part to grant additional personal servants to the aged and infirm suggests that the number of personal servants probably did not much exceed the number of nuns in private life. Those in communal life continued to be bound by the 1768 reglamento to get by on a very limited number of communal servants: one for every ten nuns. Although secular women entered the convent to care for the sick and the elderly, they did not live at the convent and were not considered servants. Santa Clara was more reformed than the average Mexican convent. In 1826, for example, there were 809 servants living in Mexico City's nineteen convents, which averaged out to forty-two and one-half servants per convent. In light of this and other evidence, Asunción Lavrin suggests that communal life was never completely accepted by the convents of Mexico. ${ }^{349}$ By contrast it appears that almost all, if not all, of the nuns of Santa Clara of Havana were living communally a

349 Lavrin, "Ecclesiastical Reform," 202. 
decade later, in 1837, which suggests that the convent had only a fraction of the number of servants in the average Mexican convent. Still the word "reformed" rings hollow for an institution that once had occupied the pinnacle of Havana's elite society. 


\section{BIBLIOGRAPHY}

\section{PRIMARY SOURCES}

Archivo General de Indias (AGI), Seville

Audiencia de México, Iegajos 2743, 2747, 2752-2759.

Audiencia de Santo Domingo (SD), legajos 325, 327, $379,380,382,383,402,414,419,420-422,514$, 515, 519-525, 922, 1118, 1133-1136, 1138, 1142-1146, $1158-1159,1306,1365,1370,1410,1411,1414,1418$, $1419,1422,1424,1454,1455,1457,1465,1466,1468$, $1473,1474,1479,1483,1486,1491,1497,2215,2222$, $2232-2241,2247,2248,2265,2266,2273,2274,2277$, 2278 .

Estado, legajos 1-19.

Indiferente General, legajos 349, 540, 2914, 30413044 , 3075 .

Papeles de Cuba, Iegajos 14, 155, 180A, 538, 594, $1071,1134,1203,1215-1222,1244,1291,1293,1295$, $1343,1373,1374,1400,1458,1497 \mathrm{~A}, 1572,1693$.

Ultramar, legajos 2, 3, 116, 119, 120, 132, 365, 366, $375,376,377,378-379,387,388,394-398$.

SECONDARY WORKS

Aiton, Arthur S. "Spanish Colonial Reorganization Under the Family Compact." The Hispanic American Historical Review 12 (1932): 269-280.

Allen, William Erancis. "Capital Formation and Lending: The Role of the Church in Guadalajara, 1750-1800." $\mathrm{Ph} . \mathrm{D}$. diss., Tulane University, 1988.

Almodóbar, Carmen. Antología critica de la historigrafía cubana: época colonial. Havana: Editorial Puebla y Educación, 1986.

Amores Carrendano, Juan Bosco. "Historiografía española sobre Cuba colonial, 1940-1989." Revista de Indias 50 (1990) : 243-255. 
Archer, Christian I. The Army in Bourbon Mexico, 17601810. Albuquerque: University of New Mexico Press, 1977 .

Arenal, Electa and Stacey Schlau, Untold Sisters: Hispanic Nuns in Their Own Works, trans. by Amanda Powell. Albuquerque: University of New Mexico Press, 1989.

Arenal, Electa. "Convent as Catalyst for Autonomy: Two Hispanic Nuns of the Seventeenth Century." In Women in Hispanic Literature: Icons and Fallen Idols, ed. Beth Miller. Berkeley: University of California Press, 1983.

Arenas Frutos, Isabel. "Auge y decadencia del sistema misional Franciscano en Florida durante el primer periodo español (1565-1763)" Añuario de Estudios Hispanoamericanos 48 (1991): 95-120.

- "El convento de Jesús María en el México criollo del siglo XVII." In Actas del I Congreso

Internacional del Monacato Femenino en España, Portugal y América (1492-1992), vol. 1: 143-154. Leon: Secretariado de Publicaciones de la Universidad de León, 1993.

Arrate, José Martín Eélix de. Llave del Nuevo Mundo: antemural de las Indias, 4th ed. Havana: Comisión Nacional Cubana de UNESCO, 1964.

Arroyo, Anita. Razón y pasión de Sor Juana. Mexico City: Editorial Porrúa, 1952.

Barbier, Jacques A. "The Culmination of the Bourbon Reforms, 1787-1804: Failure of a Bourbon Reform in Mexico and Peru." Hispanic American Historical Review 57 (1977): 51-68.

- Reform and Politics in Bourbon Chile, 1755-1796. ottawa: University of Ottawa Press, 1980.

Barbier, Jacques A. and Mark A. Burkholder, "Critique of 'Bureaucracy and Business in the Spanish Empire.'" Hispanic American Historical Review 62 (1982): 460477 (includes reply). 
Barnadas, Josep M. "The Catholic Church in Colonial Spanish America." In The Cambridge History of Latin America, vol. 1: 511-556, ed. Leslie Bethell. 8 vols. Cambridge: Cambridge University Press, 1984.

Bauer, Arnold J. "The Church in the Economy of Spanish America: 'Censos $Y$ Depositos' in Eighteenth and Nineteenth Centuries." Hispanic American Historical Review 63 (1983): 707-733.

Beers, Henry Putney. French and Spanish Records of Louisiana: A Bibliographical Guide to Archive and Manuscript Sources. Baton Rouge: Louisiana state University Press, 1989.

Bethell, Leslie, ed. Cuba: A Short History. Cambridge: Cambridge University Press, 1993.

Brading, David A. Miners and Merchants in Bourbon Mexico, 1763-1810. New York: Cambridge University Press, 1971.

- "Tridentine Catholicism and Enlightened Despotism in Bourbon Mexico." Journal of Latin American Studies 15 (1983): 1-22.

- The First America: The Spanish Monarchy, Creole Patriots, and the Liberal State, 1492-1867. Cambridge: Cambridge University Press, 1991.

Burkholder, Mark A. and Dewitt S. Chandler. From Impotence to Authority: The Spanish Crown and the American Audiencias, 1687-1808. Columbia, Missouri: University of Missouri Press, 1977.

Burkholder, Mark, A. and Lyman L. Johnson. Colonial Latin America, 2d ed. New York: Oxford University Press, 1994.

Carreras, Julio Angel. "Terratenientes e iglesia en Cuba colonial." Universidad de la Habana 196-197 (1972): 147-157.

Castañeda Delgado, Paulino, La jerarquía de la Iglesia en Indies: El episcopado americano, 1500-1850. Madrid: MAPERE, 1992 . 
Ciudad, María M. "Aspectos socioeconómicos del monacato femenino en la Guatemala colonial." In

Manifestaciones religiosas en el mundo colonial, vol. 2: 53-64. Mexico: UIA-INAH-CONDUMEX, 1994.

Cobos Mancebo, Emilia, "El convento de San Francisco de Santiago de Cuba en el siglo XVIII," Añuario de Estudios Hispanoamericanos 13 (1956): $105-123$.

Cuenca Torbio, José Manuel, "Iglesia y estado a fines del antiguo régimen: la elección del episcopado hispanoamericano (1789-1824)" Añuario de Estudios Hispanoamericanos $33(1 \overline{976}): 105-143$.

Dulles, Avery. Models of the Church. Garden City: New York, Image Books, 1974 .

Engstrand, H. W. "The Enlightenment in Spain: Influences upon New World Policy." Americas 4I (1985): 436-444.

Farriss, Nancy M. Crown and Clergy in Colonial Mexico, 1759-1821: The Crisis of Ecclesiastical Privilege. London: Athlone Press, 1968 .

Fernández Escobio, Fernando. El Obispo Compostela y la iglesia cubana del siglo XVII. Miami: Rapid Printing, 1983 .

Ferrecio Podestá, María, ed. Relación autobiográfica of Sor Ursula Suarez. Santiago: Academia Chilena de Historia, 1984.

Figueroa y Miranda, Miguel. Religión y politica en la Cuba del siglo XIX: Obispo Espada visto a la luz de los Archivos Romanos, 1802-1832. Miami: Ediciones Universal, 1975.

Fisher, John R. Government and Society in Colonial Peru: The Intendant System, 1784-1814. London: Athione Press, 1970.

- "Critique of 'The Culmination of the Bourbon Reforms." Hispanic American Historical Review 58 (1978) : 83- 90 .

- "Cultural Life in Latin America in the Age of the Enlightenment," Historian 31 (1991): 3-8. 
Fisher, John R. and Allan J. Kuethe, and Anthony McFarlane, eds. Reform and Insurrection in Bourbon New Granada and Peru. Baton Rouge: Louisiana State University Press, 1991.

Foz y Foz, Pilar. La revolución pedagógica en Nueva España: 1754-1820. 2 vols. Madrid: CSIC, 1981.

Gallagher, Sister Ann Miriam. "The Family Background of the Nuns of Two Monasterios in Colonial Mexico: Santa Clara de Querétaro, and Corpus Christi of Mexico City (1724-1822)." Ph.D. diss., Catholic University of America, 1972.

Garavaglia, Juan Carlos. "Economic Growth and Regional Differentiations: The River Plate Region at the End of the Eighteenth Century." Hispanic American Review 65 (1985): 51-90.

Garcia Palacios, Juan. Sinodo de Santiago de Cuba de 1681. Madrid-Salamanca: CSIC, 1982.

Geiger, Maynard. Biographical Dictionary of the Franciscans in Spanish Florida and Cuba, 1528-1841, vol. 21, Franciscan Studies. Patterson, New Jersey: st. Anthony Guild Press, 1940.

Gibbs, Donald L. "Cuzco, 1680-1710: An Andean City Seen Through Its Economic Activities." Ph.D. diss., University of Texas, 1979.

Góngora, Mario. "Estudios sobre el galicanismo y la 'ilustración católica' en America española." Revista Chilena de Historia 125 (1957): 5-60.

- Studies in the Colonial History of Latin America. Cambridge: Cambridge University Press, 1975.

Graham, Richard. Independence in Latin America. New York: Knopf, 1972.

Greenleaf, Richard E., ed. The Roman Catholic Church in Colonial Latin America. Tempe: Arizona State University Press, 1977. 
Gutierrez, Ramón A. When Jesús Came The Corn Mothers Went Away: Marriage, Sexuality, and Power in New Mexico, 1500-1846. Stanford: Stanford University Press, 1988 .

Hamnett, Brian R. Politics and Trade in Southern Mexico, 1750-1821. Cambridge: Cambridge University Press, 1971.

- "Church Wealth in Peru: Estates and Loans in the Archdiocese of Iima in the Seventeenth Century." Jahrbuch für Geschichte von Staat, Wirschaft und Geselischaft Lateinamerikas 10 (1973): 113-132.

Hargreaves-Mawdsley, W. N. Eighteenth Century Spain, 17001788: A Political, Diplomatic, and Institutional History. London: Macmillan Press, 1979.

Heaney, Jane Francis, OSU. A Century of Pioneering: A History of the Ursuline Nuns in New Orleans, 17271827. New Orleans: Ursuline Sisters of New Orleans, $\overline{1993 .}$

Hera, Alberto de la. "Las leyes eclesiásticas de Indias en el siglo XVIII." Añuario de Estudios

Hispanoamericanos (1958): 239-252.

- "Los precedentes del regalismo borbónico segun Mendéndez Pelayo." Añuario de Estudios Hispanoamericanos (1957): 33-39.

- "Notas para el estudio del regalismo español en el siglo XVIII." Añuario de Estudios Hispanoamericanos, 31 (1974) : 409-440.

- "El patronato indiano en la historiografía eclesiástica." Hispania Sacra 65-66 (1980): 229-264.

- El regalismo borbónico en su proyección indiana. Madrid: Ediciones Rialp, 1963.

- Iglesia y corona en la América española. Madrid: MAPFRE, 1992 .

Haring, Clarence. The Spanish Empire in America. New York: Oxford University Press, 1947; Reprint, San Diego: Harcourt, Brace, Jovanovich, 1985. 
Herr, Richard. The Eighteenth Century Revolution in Spain, Princeton: Princeton University Press, 1958.

Houtart, Francois and André Rousseau. The Church and Revolution: From the French Revolution of 1789 to the Paris Riots of 1968, from Cuba to Southern Africa. New York: Orbis, 1971.

Huerta Martinez, Angel. "El clero cubano y su participación en la enseñanza primaria (1800-1868)." Añuario de Estudios Americanos 48 (1991), 479-556.

- "El monacato femenino en Cuba durante el primer tércio del siglo XIX." In I Congreso internacional del monacato femenino en España, Portugal, y America, vol. 1: 495-511, ed. Jesús Paniagua Pérez and María Isabel Viforcos Marinas. Leon: Universidad de Leon, Secretario de Publicaciones, 1992.

Hull, Anthony H. Charles III and the Revival of Spain. Washington: University Presses of America, 1980.

Hussey, Roland. The Caracas Company, 1728-1784. Cambridge, Massachusetts: Harvard University Press, 1934.

Ismael Testé, Historia eclesiástica de Cuba, 5 vols. Burgos and Barcelona: El Monte Carmelo and Artes Gráficas Medinaceli, 1969-1975.

Jacobsen, Nils and Hans-Jürgen Phule, eds. The Economies of Mexico and Peru During the Late Colonial Period, 1760-1810. Berlin: Colloquium Verlag Berlin, 1986.

Jensen, Larry Russel. "The Mania to Write and Read: Culture and Repression in Colonial Cuba, 1790-1840." Ph.D. diss., Stanford University, 1981.

Johnson, M. Sherry. "Honor is Life": Military Reform and the Transformation of Cuban Society: 1753-1796." Ph.D. diss., University of Florida, 1995.

Kessel, John L. Friars, Soldiers, and Reformers: Hispanic Arizona and the Sonora Mission Frontier, 1767-1856. Tucson: University of Arizona Press, 1976. 
Kirk, John. Between God and Party: Religion and Politics in Revolutionary Cuba. Tampa: University of South Florida, 1989.

- "Religion and Politics in Revolutionary Cuba: A Bibliographical Guide." Revista Interamericana de Bibliografia 37 (1987): 327-343.

Knight, Franklin W. Slave and Society in Cuba during the Nineteenth Century. Madison: University of Wisconsin Press, 1970 .

Kuethe, Allan J. "Military and Society." In Latin American Revolutions, 1808-1826: Old and New World Origins. Norman: University of Oklahoma Press, 1994.

- Cuba, 1753-1815: Crown, Military, and Society. Knoxville: University of Tennessee Press, 1986.

- "More on 'The Culmination of the Bourbon Reforms' : A Perspective from New Granada." Hispanic American Historical Review 58 (1978): 477-480.

Kuethe, Allan J. and G. Douglas Inglis. "Absolutism and Enlightened Reform: Charles III, the Establishment of the Alcabala, and Commercial Reorganization in Cuba." Past and Present no. 109 (1985): 118-143.

Kuethe, Allan J. and Lowell Blaisdell. "French Influence and the Origins of the Bourbon Colonial

Reorganization," Hispanic American Historical Review 71 (1991): 579-608.

Lampros, Peter James. "Merchant-Planter Cooperation and Conflict: The Havana Consulado, 1794-1832." Ph.D. diss., Tulane University, 1980.

Laserna Gaitán, Antonio Ignacio. "El último intento de reforma de los monasterios femeninos en Perú colonial: el auto del Arzobispo Parada de 1775." Añuario de Estudios Americanos 52 (1995): 253-287.

Lavrin, Asunción. "Ecclesiastical Reform of Nunneries in New Spain in the Eighteenth Century." Americas 22 (1965): 182-203. 
- "El capital eclesiástico y las élites sociales en Nueva España a fines del siglo XVIII." In Desarrollo histórico de la burguesía en América Latina (Siglos XVIII a XX), ed. Enrique Florescano. Mexico City: Editorial Nueva Imagen, 1982.

- "El Convento de Querétaro: la administración de sus propiedades en el siglo XVIII," Historia Mexicana 97 (1975): 76-117.

- "Female Religious." In Cities and Society in Colonial Latin America, ed. Louisa Hoberman and Susan Socolow, 165-195. Albuquerque: University of New Mexico Press, 1986.

- "In Search of the Colonial Woman in Mexico: The Seventeenth and Eighteenth Centuries." In Latin American Women, ed. Asunción Lavrin, 23-59. Westport, Connecticut: Greenwood Press, 1978.

- "Lo 'femenino:' Women in Colonial Historical

Sources." In Coded Encounters. Writing, Gender, and

Ethnicity in Colonial Latin America, ed. F.J. Cevallos-Candau, J. A. Cole, et al.' 153-176.

Amherst: University of Massachusetts Press, 1994.

- "Los conventos de monjas en Nueva España," Cahiers des Ameriques Latines (Paris) 8 (1975): 92-122.

- "Missión de la historia e historiografía de la Iglesia en el periodo colonial americano." Suplemento de Añuario de Estudios Americanos: Historiografía y Bibliografía 46 (1989): 11-55.

- "Religious Life of Mexican Women in the XVII

Century." Ph.D. diss., Harvard University, 1963.

- "The Role of the Nunneries in the Economy of New Spain in the Eighteenth Century." Hispanic American Historical Review 46 (November 1966): 371-93.

- "Unlike Sor Juana? The Model Nun in the Religious Literature Mexico." University of Dayton Review 16 (1983): 75-92. 
- "Values and Meaning of Monastic Life for Nuns in Colonial Mexico." The Catholic Historical Review 58 (1972): 367-87.

- "Women and Religion in Spanish America." In Women and Religion in America, eds. Rosemary Radford Ruether and Rosemary Skinner Keller, 42-78. San Francisco: Harper and Row, 1983.

- "Women in Convents: Their Economic and Social Role in Colonial Mexico." In Liberating Women's History: Theoretical and Critical Essays, ed. Berenice A. Carroll, 256-277. Urbana: University of Illinois Press, 1976.

Leiseca, Juan Martín. Apuntes para la historia eclesiástica de Cuba. Havana: Carasa Y Cía., 1938.

Loreto López, R. "Los espacios de la vida cotidiana en los conventos de calzadas de la ciudad de Puebla (17651773)." In Actas del I Congreso Internacional del Monacato Femenino en España, Portugal y América (1492-1992), vol. 1: 201-216. Leon: Secretariado de Publicaciones de la Universidad de León, 1993.

Lynch, John. Bourbon Spain, 1700-1808. Cambridge Massachusetts: Basil Blackwell Press, 1989. - "The Origins of Spanish American Independence." In The Cambridge History of Latin America, vol. 3: 3-50, ed. Leslie Bethell. Cambridge: Cambridge University Press, 1984.

- Spanish Colonial Administration, 1782-1810: The Intendent System in the Viceroyalty of the Rio de la Plata. London: Athlone Press, 1958.

MacLachlan, Colin. Spain's Empire in the New World: The Role of Ideas in Institutional and Social Change. Berkeley: University of California Press, 1990.

Margardant, S. Guillermo Floris. Carlos III y la iglesia novohispana. Mexico: Instituto de Estudios $y$ Documentos Históricos, 1983.

Marmolego González, Jorge René. "Confesores y mujeres en el Obispado de Puebla, Siglo XVIII." In EI placer de 
pecar y el afán de normar, ed. Seminario de Historia de las Mentalidades, 147-166. Mexico City: Joaquín Mortiz, 1987.

Marrero, Levi. Cuba: Economía y sociedad. 14 vols. Madrid: Playor SA, 1972-1988.

Martin, Luis. Daughters of the Conquistadores: Women of the Viceroyalty of Peru. Albuquerque: University of New Mexico Press, 1983.

Martínez de las Heras, Agustín. "Consideraciones sobre la Isla de Cuba en tiempos de la revolución francesa." Estudios de Historia Social de America, 1-2 (1986): $301-310$.

Maza, Manuel P. "Clero católico y esclavitud en Cuba siglos XVI al XIX: ensayo de sintesis." Estudios Sociales (Dominican Republic) 23 (1990): 17-60.

- "The Cuban Catholic Church: True Struggles and False Dilemmas: The Historical Characteristics of the Cuban Catholic Church and Their Impact on the 19591960 Episcopal Documents." M.A. Thesis, Georgetown University, 1982.

McAlister, Lyle N. The Fuero Militar in New Spain. Gainesville: University of Florida Press, 1957.

McCarty, Kieren. A Spanish Frontier in the Enlightened Age: Franciscan Beginnings in Sonora and Arizona. Washington: Academy of Franciscan History, 1981.

McNeill, John Robert. "Theory and Practice in the Bourbon Empires of the Atlantic: The Roles of Louisbourg and Havana, 1713-1763." Ph.D. diss., Duke University, 1981.

McNeill, John Robert. Atlantic Empires of France and Spain: Louisbourg and Havana, 1700-1763. Chapel Hill: University of North Carolina Press, 1985.

Mecham, J. Lloyd. Church and State in Latin America: A History of Politico-Ecclesiastical Relations. Chapel Hill: University of North Carolina Press, 1966. 
Merrim, Stephanie, ed. Feminist Perspectives on Sor Juana Inés de la Cruz. Detroit, Michigan: Wayne state University Press, 1991.

Morales Moya, Antonio. "La ideología de ilustración española." Revista de Estudios Politicos (Spain) 59 (1988): 65-105.

Morell de Santa Cruz, Pedro Agustín. La vista eclesiástica, introduction by César García del Pino. Havana: Editorial de Ciencias Sociales, 1985.

Moreno Fraginals, Manuel. "Iglesia e ingenio," Revista de la Biblioteca Nacional José Martí (Cuba) 5 (1963): $11-28$

- El Ingenio: Complejo económico social cubano del azucar. 3 vols. Havana: Editorial de Ciencias Sociales, 1978.

Morner, Magnus. "The Expulsion of the Jesuits in Light of Eighteenth Century Regalism." Americas 23 (1966):156164 .

Motten, Clement G. Mexican Silver and the Enlightenment. Philadelphia: University of Pennsylvania Press, 1950.

Muriel, Josefina. Conventos de monjas en la Nueva España, Mexico: Editorial Santiago, 1946. - Las indias caciques de Corpus Christi. Mexico City: Universidad Nacional Autónoma de México, 1963.

Myers, Kathleen A. "A Glimpse of Family Life in Colonial Mexico: A Nun's Account." Latin American Research Review 28 (1993): 63-87.

- "The Addressee Determines the Discourse: The Role of the Confessor in the Spiritual Autobiography of Madre María de San Josef (1656-1719)." Bulletin of Hispanic Studies 69 (1992): 39-47.

Myer, Kathleen A. and Amanda Powell. A Wild Country Out in the Garden: The Spiritual Autobiography of Madre María de San José. Bloomington: Indiana University Press (In press). 
Navarro Garcia, Luis. Intendencias en Indias. Seville, 1959.

Nieto y Cortadellas, Rafael. Dignidades nobiliarias en Cuba. Madrid: Ediciones Cultura Hispanica, 1954.

Ocaranza, Fernando. Capitulos de la Historia Franciscana, vol. 2. Mexico: 1934.

Paz, Octavio. Sor Juan Inés de la Cruz o las trampas de la fé. Barcelona: Seix-Barral, 1982.

Peire, Jaime Antonio. "Estudio social y económico de los mercedarios de Mexico y el Caribe, 1772-1790." Jahrbüch fur Geschichte von Staat, Wirschaft und Gesellschaft Iateinamerikas (Germany) 26 (1989): 113135 .

Pérez Cabrera, J. M. "Archdiocese of Havana." In New Catholic Encyclopedia. New York: Mcgraw-Hill, 19671979.

Pérez Cabrera, J. M. "Archdiocese of Santiago de Cuba." In New Catholic Encyclopedia. New York: Mcgraw-Hill, 1967-1979.

Pérez, Jr., Louis A. Cuba: Between Reform and Revolution. Oxford: Oxford University Press, 1988.

- "In service to the Revolution: Two Decades of Cuban Historiography, 1959-1979," Hispanic American Historical Review 60 (1980): 79-89.

- "Twenty-Eive Years of Cuban Historiography: Views from Abroad." Cuban Studies 18 (1988): 87-101.

Pérez-Marchand, Monalisa Lina. Dos etapas ideológicas del siglo XVIII. Mexico: Colegio de Mexico, 1945.

Phelan, John Leddy. "Authority and Elexibility in the Spanish Imperial Bureaucracy." Administrative Science Quarterly (1960): 47-65.

Pons, Frank Moya, "Haiti and Santo Domingo," in The Cambridge History of Latin America, vol. $3: \frac{1}{23} 7-275$, ed. Leslie Bethell. 8 vols. Cambridge: Cambridge University Press, 1985. 
Pruna, P.M. Los Jesuitas en Cuba hasta 1767. Havana: Editorial de ciencias sociales, 1991.

Priestly, Herbert J. José de Gálvez, Visitor-General of New Spain (1765-1771). Berkley: University of California Press, 1916.

Rodríguez Casado, Vicente. "La orden de San Francisco y la visita general de reforma de 1769." Añuario de Estudios Hispanoamericanos 9 (1952): 209-233.

Royer, Franchon. The Tenth Muse: Sor Juana Inés de la Cruz. Patterson, New Jersey: St. Anthony Guild Press, 1952 .

Salazar de la Garza, N. La vida común en los conventos de monjas de la ciudad de Puebla. Puebla, Mexico: Biblioteca Angelopolitana Gobierno del Estado de Puebla, Secretaría de Cultura, 1990.

Sánchez Bella, Ismael. Iglesia y Estado en la America española. Pamplona: Ediciones de la Universidad de Navarra, 1990.

Sánchez Rodríguez, María. "La mujer, el amor y la religión en el Antiguo Régimen." In La mujer en la historia de España (siglos XVI-XX). Actas de las Segundas Jornadas de Investigación Interdisciplinaria organizadas por el Seminario de Estudios de la Mujer de la Universidad Autónoma de Madrid, 35-58. Madrid: Universidad Autónoma, 1984.

Sarabia Viego, María Justina, "Monacato femenino y problemática indígena en la Nueva España del siglo XVIII." In Actas del I Congreso Internacional del Monacato Femenino en España, Portugal y América (1492-1992), vol. 1: 173-185. Leon: Secretariado de Publicaciones de la Universidad de León, 1993.

- "Controversias sobre la 'vida común' ante la reforma monacal femenina en México." In Actas del II Congreso Internacional del Monacato Femenino en España, Portugal, y América (1492-1992), vol. 2: 583-592. Mexico: DF, 1995)

- "La Concepción de Corpus Christi. Raza y vida conventual femenina en México, siglo XVIII." In 
Manifestaciones religiosas en el mundo colonial, vol. 2: 15-27. MeXico: UIA-INAH-CONDUMEX, 1994.

Sarrailh, Jean. L'Espagne Eclairée de la seconde moitié du XVIIIe siécle. Paris: Impr. Nacionale, 1954.

- La España ilustrada de la segunda mitad del siglo XVIII. Mexico and Buenos Aires: Fondo de Cultura Económica, 1957.

Sayers-Peden, Margaret. A Woman of Genius: The Intellectual Autobiography of Sor Juana Inés de la Cruz. Salisbury, Connecticut: Lime Rock Press, 1982.

Schmitt, Karl. "The Clergy and the Enlightenment in Latin America: An Analysis." The Americas 15 (1959): 381391.

Schnelle, Kurt, "El siglo XVIII e hispanoamérica." Islas (Cuba) 65 (1980): 129-139.

Schwaller, John Frederich. Origins of Church Wealth in Mexico, Ecclesiastical Revenues and Church Finances, 1523-1600. Albuquerque: University of New Mexico, 1985.

Seed, Patricia. To Love, Honor, and Obey in Colonial Mexico: Conflicts Over Marriage Choice, 1574-1821. Stanford: Stanford University Press, 1988.

Segura, Cristina, ed. Ia voz del silencio: S. VIII-XVIII. Euentes directas para la historia de las mujeres. Madrid: Colección Laya, 1992.

- ed. Religiosidad femenina: expectativas $y$ realidades (siglos XIII-XVIII) . Madrid: Colección Laya: 1991.

Shiels William Eugene. King and Church: The Rise and Fall of the Patronato Real. Chicago: Loyola University Press, 1961.

Smith, Robert Freeman. "Twentieth-Century Cuban Historiography." Hispanic American Historical Review 44, no. 1 (Eebruary 1964): 44-73. 
Socolow, Susan. The Merchants of Buenos Aires, 1778-1810. Cambridge: Cambridge University Press, 1978.

Soeiro, Susan A. "A Baroque Nunnery: The Economic and Social Role of a Colonial Convent: Santa Clara do Desterro, Salvador, Bahia, 1677-1800." Ph.D. diss., New York University, 1974.

- "The Feminine Orders in Colonial Brazil: Economic, Social, and Demographic Implications, 1677-1800." In Latin American Women: Historical Perspectives, ed. Asunción Lavrin, 173-197. Westport Connecticut: Greenwood Press, 1978.

- "The Social and Economic Role of the convent: Women and Nuns in Colonial Bahia, 1677-1800." Hispanic American Historical Review 54 (1974) : 209-232.

Stein, Stanley J. "Bureaucracy and Business in the Spanish Empire, 1759-1804: Failure of a Bourbon Reform in Mexico and Peru." Hispanic American Historical Review 71 (1981): 2-28.

Stein, Stanley J. and Barbara H. Stein. The Colonial Heritage of Latin America. New York: Oxford University Press, 1970.

Suchlicki, Jaime. Cuba: From Columbus to Castro. New York: Charles Scribner's Sons, 1974; Reprint, Macmillan Publishing, 1990.

Tenenbaum, Barbara A., Georgette Magassy Dorn, Mary Karasch, John Jay TePaske, Ralph Lee Woodward, Jr. Encyclopedia of Latin American History and Culture. 5 vols. New York: Charles Scribner's Sons, 1996.

Testé, Ismael. Historia eclesiástica de Cuba. 5 vols. Burgos and Barcelona: EI Monte Caramelo and Artes Gráficas Medinaceli, 1969-1975.

Thomas, Hugh. Cuba: The Pursuit of Freedom. Iondon: Eyre and spottiswoode, 1971.

Torres Ramírez, Bibiano. "Aleandro O'Reilly en Cuba," Añuario de Estudios Americanos (1967): 1357-1368. 
Torres Cuevas, Eduardo. "El obispado de Cuba: genesis, primeros prelados, y estructura." Santiago (Cuba) 2627 (1977) : 61-98.

- "Formación de las bases sociales e ideológicas de la Iglesia Católico-criolla del siglo XVIII." Santiago (Cuba) 48 (1982): 153-188.

- Obispo Espada: Ilustración, reforma y antiesclavismo. Havana: Editorial de Ciencias Sociales, 1990 .

Trelles, Carlos, M. Bibliografía cubana de los siglos XVII y XVIII. Havana: Galieno de la República de Cuba, 1927 .

Valdés, Antonio José. Historia de la Isla de Cuba y en especial de la Havana. Havana: Oficina de la Cena, 1813; fascimile ed. Havana: Comisión Nacional Cubana de UNESCO, 1964.

Vargas Ugarte, Rubén, S.J., El monasterio de La Concepción de la Ciudad de los Reyes. Iima: Talleres Gráficos de Ia Editorial Lumen, 1942 .

Vélez Sarsfield, Dalmacio. Relaciones del estado con la iglesia. Buenos Aires: Librería de Juan Rolden, 1930.

Venegas Fornias, Carlos. "La Habana proclama un rey." Revista de Biblioteca Nacional José Martí (Cuba) 23 (1981): 105-117.

Vergara Quiroz, Sergio. "Iglesia y Estado en Chile: 17501850." Historia (Chile) 20 (1985): 319-62.

Walker, Geoffrey. Spanish Politics and Imperial Trade, 1700-1789. Bloomington: University of Indiana Press,

Whitaker, Arthur R., ed. Latin America and the Enlightenment. New York: Cornell University Press, 1961.

Wright, A.D. "The Institutional Relations of Church and State in the Overseas Iberian Territories." Hispania Sacra 40 (1988): 693-699. 
APPENDIX A

THE REGLAMENTO OF 1768

1. Aunque no nos consta haber en la iglesia y locutorios de dicho nuestro monasterio planchas de hierro que señor Urbano prescribe al capitulo 16 de la regla las haya $y$ sean sutilmente agujereadas; sin embargo en el caso de que se verfiquen, mandamos que los agujeros sean mayores $y$ se abran al tamaño y propoción de los que tienen las zelosias regulares que disponen las constituciones del año de 1639 al párrafo 12 del capitulo 8.

2. Por que hemos llegado a entender que en contravención de lo que se halla dispuesto en el párrafo 28 del capitulo 14 de dichas constituciones, conforme a la bula de Clemente VIII romani pontificis expedida en 24 de Abril de 1600 ejerce el empleo de mayordomo de dicho monasterio un religioso de nuestra orden, aunque no podemos persuadirnos ser esto así, y solo concevimos que ejercerá el de superintendente pura y sanamente extendido y permitido en los párrafos 16 y 19 del citado capítulo 14; sin embargo conformandonos aun con los materiales términos del motu proprio del Señor Inocencio XI expedido en el año de 1679 que empieza solicitudo, y para evitar expensas abolimos dicho empleo y título de superintendente y mandamos 
estrechamante que ningun religioso nuestro lo ejercía, y que la madre abadesa y discretas del monasterio con aprobación del reverendo padre provincial y del padre vicario elijan con todas las cautelas necesarias para la seguridad de los caudales un secular bien abonado, que como mayordomo sindico, cobrador o como mejor les pareciese, se encargue de las rentas y negocios de el asignando le aquel salario que se considerase justo $y$ razonable al trabajo y cuidado que podrá tener. 3. En antención a los graves inconvenientes y daños que han reslutados por haber corrido de cuenta del superindente $y$ de dos religiosas contadoras la imposición de las dotes de las religiosas y de censos redimidos, absolutamente revocamos práctica tan expuesta a perjuicio y ordenamos que en adelante conforme al parrafo 8 de dicho capitulo 14 cuiden por si estos negocios la madre abadesa y discretas $y$ otorguen las escrituras correspondientes con asistencia $y$ intervención del padre vicario obsteniendo antes la aprobación de las fincas por escrito del reverendo padre provincial cuya conciencia cargamos por ser la materia tan importante. 4. Y por que para la más exacta observancia de la vida común, tan necesaria, para que no decaiga la disciplina 
regular, se prohibe con penas en el párrafo 7 de capítulo $4 y$ en el tercero del capítulo 14 el administrar a las religiosas la ración en dinero; mandamos bajo las mismas, $y$ de otras a nuestro arbitrio, se execute puntualmente como en ello se contiene entendiendose tambien las misma providencia en cuanto al vestuario y demás cosas que necesiten segun su pobre estado. Y atento a que esto mismo se dispone al capítulo 5 de los confesores de monjas, párrafo 11 de los estatutos de Barcelona revistos en Segovia para con el padre vicario y su compañero se practicará igualmente con estos lo que queda ordenado para con las religiosas, trandolos con la decencia correspondiente, y debida, segun el estado a sacerdotes del altisimo y padres espirtuales suyos. 5. Por cuanto hemos llegado a entender, que las religiosas que sierven las oficinas de sacristia, enfermeria, y otros que hay en el monasterio molestan a sus padres y pareientes para subvenir a los gastos que en ellas ocurren por que no alcanza lo que suministra la comunidad. Considerando que este daño proviene de abusos introducidos sin reflexión, establecemos para en adelante que el reverendo padre provincial con la madre abadesa $y$ discretas del monasterio examine con toda circunspección 
todos Ios que se hallaren de costumbre, reformen $y$ quitenlos que fueren superfluos y no precisos gastos, señalando los que deberán hacer las oficialas con sus respectivas oficinas, y que para su desempeño se contribuya con lo necesario de las rentas del convento, y cada oficiala lleve su cuenta y razon que deberá dar mensualmente a las expresadas madre abadesa y discretas para que en todo se proceda con el mayor arreglo. 6. Teniendo muy presente lo que el santo Concilio de Trento dispone al capitulo 3 de la sesión 25 de regularibus et monialibus y el capitulo general de Toledo de 1673, con el mandamos que de 10 en 10 años se haga en dicho monasterio por el difinitoro de la provincia la calculación y nueva tasa del numero de religiosas que deberá haber en el, proporcionandola de suerte que hechos todos los gastos según el nuevo arancel, que luego deberá formar el reverendo padre provincial con asistencia $y$ consentimiento del padre vicario y de la madre abadesa con sus discretas, quede añualmente de las rentas del convento algun sobrante considerable para acudir en las ocurrencias fortuitas y urgentes. Y para lo presente asignamos $y$ señalamos el numero de 90 religiosas, ordenando bajo de nulidad de recepciones y profesiones no se exceda en 
adelante, y se reduzca al mismo, el que hay de presente conforme fueren muriendo las religiosas. De tal manera, que interin no se verifique la efectiva rebaja hasta el numero asignado de las 90 , no pueda darse avito alguno. Y por que podran acontecer algunos casos graves en que se quiera estrechar a la comunidad a admitir alguna o algunas supernumerarias y frustrarse por este medio los santos fines del citado Concilio, ordenamos bajo las mismas penas de nulidad que ninguna sea admitida sin la duplicada dote que previene el párrafo 3 del capítulo 2 de las constituciones $y$ tiene dispuesto la sagrada congregación por decreto general expedido en 6 de septiembre de 1604 y en otros particulares casos que se han ofrecido, 0 a 10 menos sin que obtenga la parte dispensa apostolica, y esta sea aprobada por nos o nuestros sucesores $y$ admitidas por el real y supremo Consejo de Indias. Por la misma razón, $y$ otras muy justifacadas que tienen a la vista, prohibimos expresamente la admisión en la clausura de mujeres seglares que excedan el numero de 15, y mandamos que las criadas de comunidad que corresponde una por diez religiosas, y las que hubieran particulares por dispensa apostolica no excedan la edad de los 40 años ni bajen de los 12 para que sean utiles al servicio sin que tengan 
necesidad de ser servidas, y que en lo demás se cuide con mucha especialidad en la observancia de cuanto contiene todo el capitulo 13 de las constuciones.

7. Por que es conocido abuso el que las religiosas y sus criadas se emplean en hacer dulces para granjería, $y$ otros regalos indebidos de que sobre otros inconvenientes resultan muchos perjuicios al estado de pobreza que profesaron, prohibimos del todo este genero de labor y otro qualquiera que sea semejante $y$ menos honesto, sin que por esto entendamos prohibir los dulces que puedan hacerse para el gasto de la comunidad de las religiosas enfermas, y demás que deban cosumirse dentro del monasterio. Y exortamos a todas se contenten para quitar la ociosidad enemiga del alma con labores de manos correspondeientes a la vida monástica, arreglandose en cuanto sea posible al método que se previene en el párrafo 12 de capítulo 4 de sus constituciones para que al mismo tiempo que las manos se ocupan en el trabajo material, elevan los entendimientos a consideraciones santas propias del estado religioso: y teniendo noticia que en los dias de nuestro santo patriarca $y$ otros del año se dan comidas indebidas asi a los prelados ministros del altar, predicadores, y a otros religiosos, ordenamos y mandamos que en adelante de 
ningun modo por título alguno se les administre semejantes comidas, como impropias a nuestro sagrado seráfico instituto. $Y$ si por algun caso contingente urgentisimo $Y$ grave aconteciera darles de comer en estas circunstancias se le previene $y$ manda a la madre abadesa y religiosas que solo se les administre el sustento de comida y bebida del que hacieran en nuestros conventos lo que la madre abadesa deberá executar bajo la pena de suspensión de su oficio por tres meses, $y$ las religiosas que a ello contravinieran habrán la penitencia de comer debajo de la mesa por un mes continuo $y$ decir su culpa ante la abadesa y su comunidad, y Ios religiosos que no se ajustaran a nuestro mandato serán privados de sus oficios con otras penas que a nuestro arbitrio reservamos.

8. Siendo como es cierto que de permitir a los padres $y$ parientes de las religiosas el fabricar celdas para ellas se siguen continuas desazones entre ellos y la comunidad, mandamos en virtud de santa obedencia y pena de nulidad de cuanto en contrario se obrara que ningun prelado provincial conceda licencia para semejante efecto ni permita el compra de las ya fabricadas, sino es con la precisa condición de que muerta la religiosa para quien se fabricara o comprara hayan de quedar absolutamente para la 
comunidad, y que despues disponga de ellas la madre abadesa con dictamen y aprobación de las discretas. 9. Se ordena con arreglo a lo prevenido y dispuesto por nuestro predecesor Fray Julián de Chumillas en 20 de septiembre de 1688, y mandado executar por real cédula de 5 de diciembre del mismo año, y conforme a otras letras patentes de su inmediato sucesor Fray Antonio de Cardona que instado por papal del Consejo [de Indias] de 21 de Junio de 1697 las expidió con fecha de 27 del mismo mes $y$ año que en adelante no excedan las propinas de las religiosas de un real de a ocho de plata por cada una; pero mandamos estrechamante para evitar inconvenientes que ninguna religiosa pueda recibirlas antes de sufragan $y$ dar su voto sobre la admisión de la pretendiente al santo habito y profesión respectivamente. 10. Por cuanto estamos asegurados que las religiosas de dicho nuestro monasterio acordandose de las etiquetas del mundo (que deben tener bien olvidados) han introducido $y$ aun fomentan con emulación entre si el detestable abuso de visitas de duelos y placemes con la misma o mayor formalidad que entre personas seglares se aconstumbra, sirviendose en ellas mutualmente de dulces y refrescos de que nace una total distracción de espiritu con detrimento 
conocido de la santa pobreza y son causa de continuas ruinas espirituales, a que como pastor y prelado debemos aplicar el oportuno remedio para desterrar de los religiosos claustros tan pernicioso modo de vida; mandamos a todas y cada una de las religiosas de dicho nuestro monasterio de qualquiera graduación que sean pena de privación de voz activa $y$ pasiva en que queremos incurran por el mismo hecho se abstengan en un todo de dichas visitas, y las exhortamos por las entrañas de cristo nuestro bien y su santismima madre a que el precioso tiempo que en ellas pierden aprovechen en las visitas del santismimo sacramento y otras obras de caridad para que cuando llegue la hora de la media noche en que las llame su divino esposo se vean como virgines prudentes con atorchas encendidas en las manos, $y$ en su compania entren en el celestial paraiso.

11. Por que en el párrafo sexto del capítulo 4 de las constituciones se dispone que todas las religiosas coman $y$ cenen en el refectorio de la olla común y este es uno de los medios más eficaces para sostener la vida monástica y evitar muchos inconvenientes, ordenamos que puntualmente se ejecute asi siendo las primeros en dar exemplo a las demás, las más graduadas y solo cuando la madre abadesa 
conociera haber suficiente causa podrá dispensar en esto con alguna o algunas religiosas en 10 que procurará prudente no ser demasiadamente escrupulosa si llegara a concebir que la pretensión de la religiosa no tiene origen de la relajación.

12. Aunque por el párrafo 6 del capitulo 10 titulo de las rederas 0 escuchas se dispone que en la parte interior de Ios locutorios haya un velo para que las religiosas se estén con más decencia $y$ honestidad, sin embargo conformandonos con la practica casi común de estas partes permitimos no se use de tal velo; pero encargamos seriamente a todas las religiosas que cuando huvieran de tratar con personas de diverso sexo de qualquiera calidad y condición que sean, procuren cubrir su rostro con el velo que para este fin tienen destinado asi por evitar la ocasión de ruina espiritual del próximo, como para dar buen exemplo con el debido recato. 13. Hallandonos bien instruidos que cuando los maytines se rezan a las ocho de la tarde, como previene el párrafo 3 del capitulo 3 de las constituciones, es cortísimo el numero de religiosas que asisten a cumplir esta parte del oficio divino, de suerte con fundamento se puede dudar si a el se satisface en una comunidad tan numerosa $y$ por otra 
se nos asegura que diciendose a las 4 de la tarde es rara la religiosa que falta de su asistencia, nos ha parecido conveniente dispensar en cuanto a la hora señalada en dicho estatuto $y$ disponer como disponemos que de aqui en adelante se recen o canten los maytines a las 4 de la tarde, obsevandose puntualmente el párrafo 2 del mismo capitulo en que se manda que durante el oficio divino estén cerrados los tornos y locutorios cuyas llaves recogerá a tiempo la madre abadesa.

14. Sin embargo de constarnos que en los tornos de la sacristía y portería hay agujeros por los que las religiosas pueden ver $y$ ser vistas contra lo que dispone el capitulo 14 de su regla, para obviar graves inconvenientes que ese han experimentado permitimos que en adelante subsistan, pero con la indispensable y precisa condición de que para la observancia substancial de dicho capitulo de regla, tome la madre abadesa providencia pronto de poner en los referidos agujeros planchas de hierro en forma de pasador para que se use de ello solamente cuando fuese necesario. 15. Confomandonos con el párrafo 10 del capítulo 8 de las constituciones en que se ordena que todas las ventanas del monasterio aunque caigan a lo interior de el tengan rejas 
fuertes de hierro, mandamos se ejecute esto con la mayor prontitud en las dos ventanas bajas que tiene el coro inferior para que asi se cuide mejor de la clausura segun la intención de la silla apostolica, y que de la más escogida porción del rebaño de Cristo libre y asegurada de todo insulta.

Y ultimamente ordenamos y mandamos la más puntual observancia de las constituciones que recopiladas de las antiguas $y$ formadas de nuevo dispuso y publico el capitulo general que se celebró en Roma el año de 1639 para el mejor gobierno de las religiosas que profesan la regla de la Santa Madre Clara mitigada por el Señor Urbano 15 sobre que encargamos el celo de todas las que quieran es mirarse como deben en ser verdaderas hijas e imitadoras de Santa Madre.

Y para que todo lo que va dispuesto tenga el deseado efecto y su olvido no sea causa para la inobservancia, determinamos con arreglo a lo que dispone el párrafo 3 del capitulo 15 de las mismas constituciones se lean estas nuestras letras con ellas en plena comunidad por los meses de enero, mayo, y septiembre de cada año, a cuyo fin se pondrá su copía a continuación de las que corren impresas $y$ tambien en el registro de provincia quedandose estas 
archivadas para que los superiores de ella las tengan siempre a la vista como especuladores que deben ser de su más exacto cumplimiento y a demás estarán obligados a dar aviso puntual de cuanto ocurra a este oficio de resulta de cada una de las visitas que hacieran en dicho nuestro Monasterio de Santa Clara de la Habana bajo la pena de suspensión de su empleo por su desidia en el cuidado de su pastoral obligación. Source: AGI, SD 1136, Reglamento, November 23, 1767, quoted in the consulta of January 7, 1768. Underlining in original. 
APPENDIX B

WEALTH OF FEMALE ORDERS IN 1837

(Amounts in Pesos)

\begin{tabular}{|c|c|c|c|c|}
\hline Convent & $\begin{array}{l}\text { Urban } \\
\text { Investments }\end{array}$ & $\begin{array}{l}\text { Rural } \\
\text { Investments }\end{array}$ & $\begin{array}{l}\text { Capital } \\
\text { Earning } 5 \%\end{array}$ & Totals \\
\hline $\begin{array}{l}\text { Santa } \\
\text { Clara }\end{array}$ & 144,585 & & 801,951 & 946,536 \\
\hline $\begin{array}{l}\text { Santa } \\
\text { Catalina }\end{array}$ & 220,000 & 110,000 & 201,885 & 531,885 \\
\hline $\begin{array}{l}\text { Santa } \\
\text { Teresa }\end{array}$ & 336,846 & & 172,523 & 509,369 \\
\hline $\begin{array}{l}\text { Ursuline } \\
\text { Convent }\end{array}$ & 66,149 & & 68,579 & 134,724 \\
\hline
\end{tabular}

255 


\section{APPENDIX C}

RELIGIOUS POPULATION OE SANTA CLARA, 1768-1811

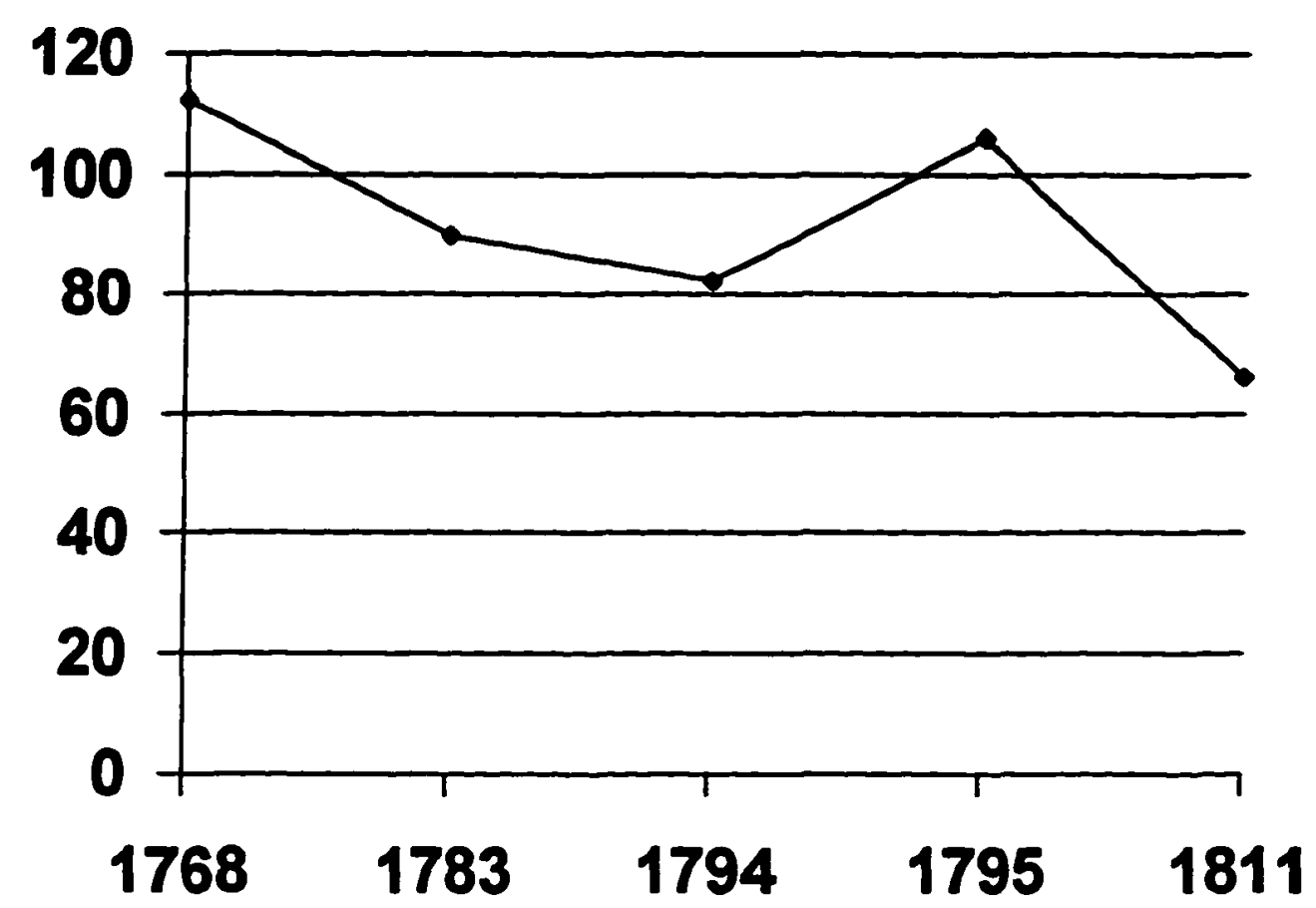

Sources: AGI, Ultramar 396, Pablo de Moya to Francisco Cerdá, August 20, 1796, Consulta, December 22, 1796 and Royal Order, June 8,1813 , summarized in the expediente of the Council of the Indies, 1813. 


\section{VITA}

Born in New Orleans, Louisiana, in April of 1964, John Clune grew up sixty miles southwest of the city, in Houma. After receiving a bachelor of science in marketing from Nicholls State University in 1986, John served two years as a Peace Corps Volunteer in Guatemala. Upon returning to the United States, he entered the graduate program in Latin American Studies at the University of Alabama, receiving a master of arts degree in December of 1990. He entered the doctoral program in history at Louisiana State University in 1991. As a graduate student at I.S.U., he received a Fulbright Grant in 1995 to research his dissertation at the Archivo General de Indias in Seville, Spain. While in Spain, he was named recipient of the John A. Perry Fellowship in Latin American Studies by the History Department at L.S.U. His doctor of philosophy degree will be conferred in August of 1997. John currently resides in Pensacola, Florida with his wife and daughter. 


\section{DOCTORAL EXAMINATION AND DISSERTATION REPORT}

Candidate:

Winor Field:

Title of Dienertation:
John James Clune, Jr.

History

A Cuban Convent in the Age of Enlightened Reform: The Observant Franciscan Community of Santa Clara of Havana, 1768-1808.

\section{Approved:}

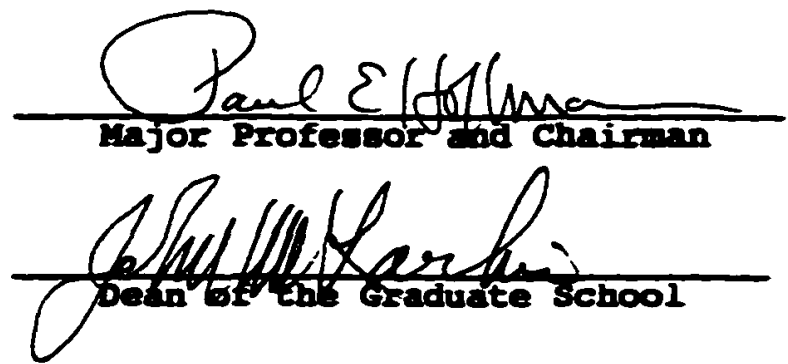

\section{EXAMINING COMLITIEE:}
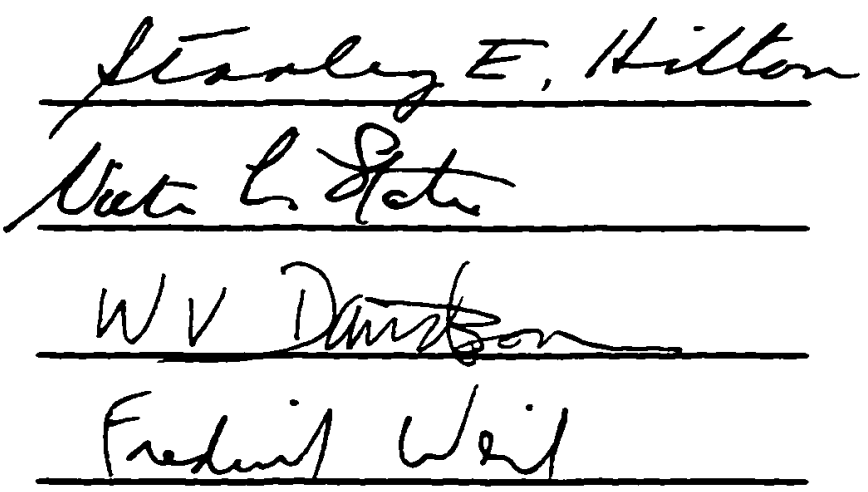

\section{Date of Bxamination:}

Iune 24, 1997 